\title{
SERVING NONCUSTODIAL PARENTS: \\ A DESCRIPTIVE STUDY OF WELFARE-TO-WORK PROGRAMS
}

\author{
Karin Martinson, The Urban Institute \\ John Trutko, The Urban Institute \\ Debra Strong, Mathematica Policy Research, Inc.
}

December 2000

\author{
The Urban Institute \\ 2100 M Street N.W. \\ Washington, D.C. 20037
}

This report was funded by the Office of the Assistant Secretary for Planning and Evaluation, U.S. Department of Health and Human Services, under contract No. 100-98-0009 with Mathematica Policy Research, Inc., and its subcontractors, the Urban Institute and Support Services International, as part of the Evaluation of the Welfare-to-Work Grants Program. Views expressed are those of the authors and do not represent official positions of the Department of Health and Human Services, Mathematica Policy Research, Inc., the Urban Institute, its trustees, or its sponsors. 


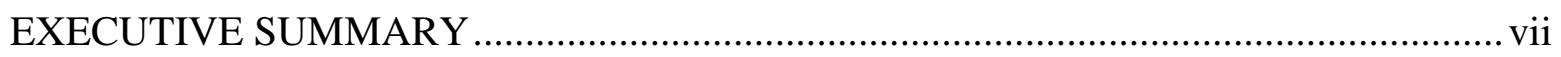

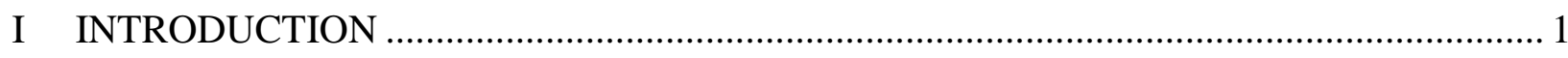

A. Issues Facing Low-Income Noncustodial Parents..................................................... 3

B. Overview of the Welfare-to-Work Grants Program ............................................... 6

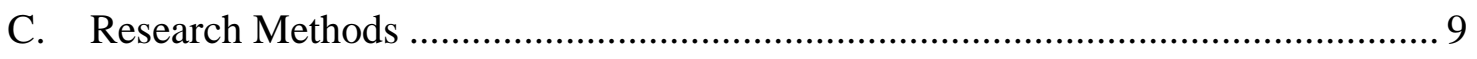

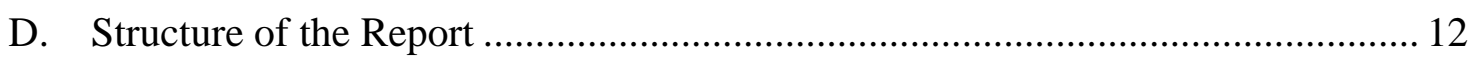

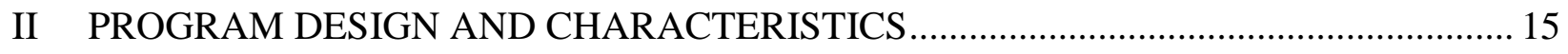

A. Sponsoring Agencies and Partnerships with Other Organizations.......................... 15

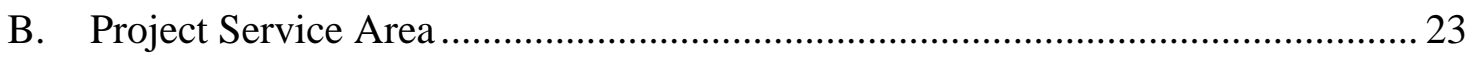

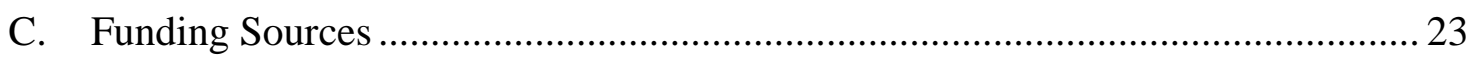

D. Participation Levels and Target Groups Served .................................................... 25

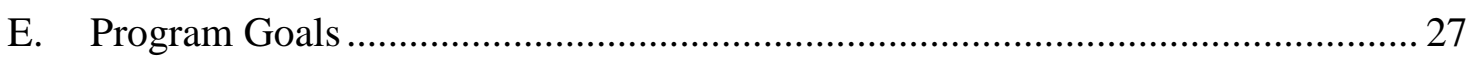

III GETTING NONCUSTODIAL PARENTS TO PARTICIPATE ......................................... 31

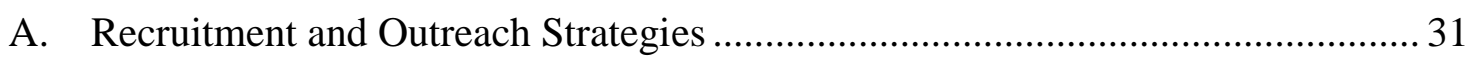

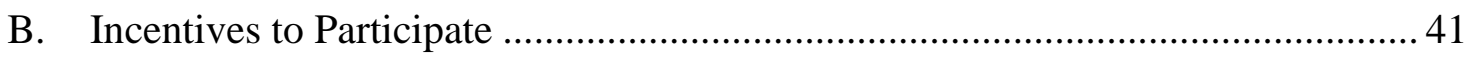

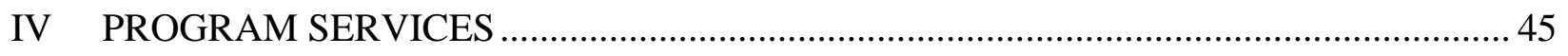

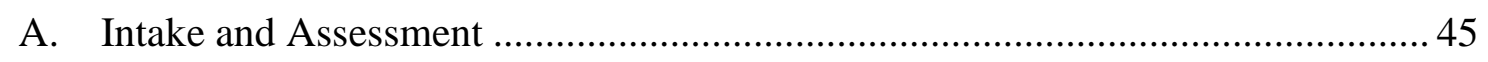

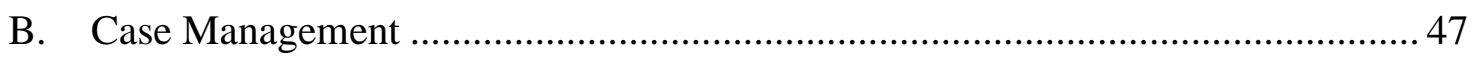

C. Employment and Postemployment Services ……................................................. 49

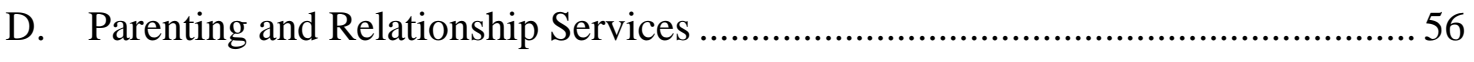


E. Other Types of Services

$\mathrm{V}$ CONCLUSIONS

REFERENCES

\section{APPENDIX A:PROFILES OF THE NCP STUDY PROGRAMS}

DeKalb County Fatherhood Connection, Decatur, GA....................................................... 75

Full Employment Council's Concerned Parent Program, Kansas City, MO ……………...... 79

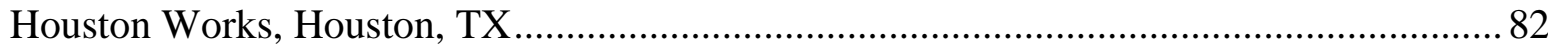

Institute for Responsible Fatherhood and Family Revitalization (IRFFR),

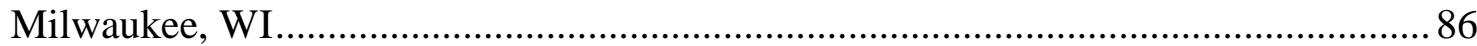

Los Angeles County Private Industry Council Noncustodial Parent-to-Work (NCPtW) Program, Los Angeles, CA ………………............................................. 90

LAVeterans in Progress Fathers Welfare-to-Work Program, Los Angeles, CA ................... 94

Milwaukee County Private Industry Council, Milwaukee, WI.............................................. 98

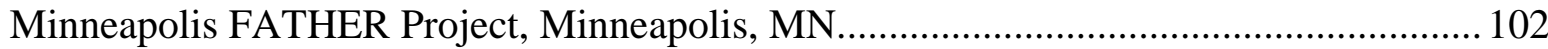

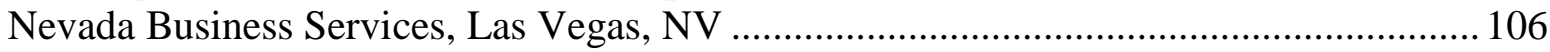

Wisconsin Department of Corrections NOW Program, Milwaukee, WI............................... 111

Yakima SHARE Program, Yakima, WA .......................................................................... 115

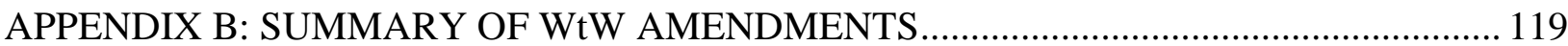




\section{EXHIBITS}

Exhibit

Page

I-1 PROGRAMS INCLUDED IN WtW NONCUSTODIAL PARENT

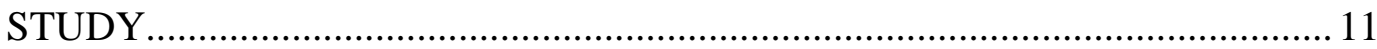

II-1 KEY BACKGROUND FEATURES OF NONCUSTODIAL

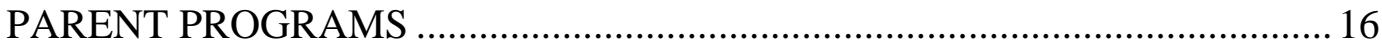

II-2 ROLE OF THE CHILD SUPPORT ENFORCEMENT AGENCY IN

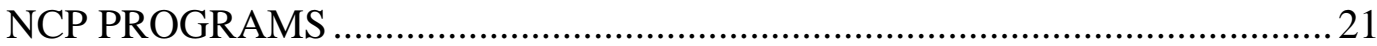

III-1 RECRUITMENT METHODS AND INCENTIVES TO

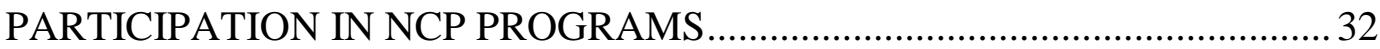

IV-1 EMPLOYMENT AND POSTEMPLOYMENT SERVICES

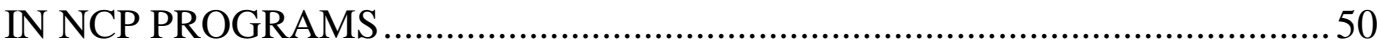

IV-2 PARENTING AND OTHER SERVICES IN NCP PROGRAMS .......................57 


\begin{abstract}
The Welfare-to-Work (WtW) Grants Program presents an important opportunity for states and localities to provide employment services to noncustodial parents.

This study examines the strategies that 11 purposively selected WtW grantees used to design and operate programs serving this population. It also summarizes lessons that can be learned from these efforts-lessons that are applicable to the larger community of workforce development and social services agencies which would like to be more proactive in serving low-income noncustodial parents. Specifically, the report examines program design and characteristics, recruitment and outreach strategies, incentives for participation, and program services (including employment, post-employment, and parenting services).
\end{abstract}




\section{EXECUTIVE SUMMARY}

The Welfare-to-Work (WtW) Grants Program, authorized by the Balanced Budget Act of 1997, provides federal funding to states and local organizations to help welfare recipients and other low-income parents move into employment, stay employed, and improve their economic situation. Low-income noncustodial parents (NCPs) (mainly fathers) of welfare children are among the main target groups for WtW services, along with custodial parents who are receiving cash assistance under the Temporary Assistance for Needy Families (TANF) program and moving from welfare to work. This focus reflects policymakers' growing interest in strategies to increase the employment and earnings of noncustodial fathers and thereby improve their ability to provide financial support for their children and play an active role in their lives.

WtW grants represent a new source of funding for local work-focused services to NCPs. This report describes 11 local programs funded by WtW grants, in terms of the types of organizations operating the programs, the range of services offered, and the interagency

\section{WTW PROGRAMS FOR NONCUSTODIAL PARENTS INCLUDED IN THIS REVIEW}

- DeKalb Fatherhood Connection, Atlanta, Georgia

- Full Employment Council's Concerned Parent Program (CPP), Kansas City, Missouri

- Houston Works, Houston, Texas

- Institute for Responsible Fatherhood and Family Revitalization (IRFFR), Milwaukee, Wisconsin

- LA County Noncustodial Parent-to-Work Program, Los Angeles, California

- LA Veterans in Progress Program, Los Angeles, California

- Milwaukee County Private Industry Council WtW Competitive Grant Program, Milwaukee, Wisconsin

- Minneapolis FATHER Program, Minneapolis, Minnesota

- Nevada Business Services, Las Vegas, Nevada

- Wisconsin Department of Corrections NOW Program, Milwaukee, Wisconsin

- Yakima SHARE Program, Yakima, Washington 
collaborations in effect. No single strategy or set of services predominates. Rather, local grant recipients have discretion in developing and implementing program models, within the parameters of the $\mathrm{WtW}$ regulations. Thus, the experiences of these programs illustrate a variety of strategies and approaches that are being implemented around the nation and highlight key issues that must be addressed to serve this population group.

\section{DESIGNING EMPLOYMENT-FOCUSED PROGRAMS FOR NCPS}

The main goals of these $\mathrm{WtW}$-funded programs are employment and job retention. The priority for these programs is to help the NCP find and keep a job. However, each program also consciously recognizes the goal of increasing child support payments. Other goals, such as improving parenting skills or upgrading job skills, are generally considered secondary, although in at least one program (the Institute for Responsible Fatherhood and Family Revitalization), family connections and improved parenting are the top objectives.

The availability of WtW grant funds spurred an interest in, or added further impetus for, serving NCPs. In some of the sites visited, the grants encouraged the initiation and development of programs for fathers; in other sites, the grants represented a new source of funds to expand or enhance preexisting programs focusing on fatherhood and child support.

A variety of organizations are implementing programs for NCPs. Six of the programs reviewed are operated by workforce development agencies; the other five are administered by other types of agencies, including nonprofit community-based organizations and a corrections department. This suggests that various types of organizations can implement and operate programs for this group.

These WtW programs bring together a wide range of partners to meet the varied needs of low-income NCPs. The program partners include workforce development agencies, community-based organizations, child support enforcement agencies, the courts, and TANF agencies. Collaboration has occurred in designing and funding, as well as in operating, the program - in particular, especially in recruiting and referring eligible fathers, and in providing special services, such as legal assistance or treatment for mental health or substance abuse. Coordination is promoted when partnering agencies agree on the goals of the program and when $\mathrm{WtW}$ funds are available to encourage more formal collaboration.

Many of these WtW programs involve child support enforcement agencies. The role of the child support enforcement agency varies among the programs and includes providing direct referrals from the agency or court, providing flexible child support payment options for program participants, and designating staff to work with participants on child support issues. Making a commitment to the service-focused NCP program, however, requires a paradigm shift for the staff of the child support agency, since their primary mission is to collect child support.

Funding sources greatly influence the program designs and the collaborative partnerships. All these programs are funded totally or partly by $\mathrm{WtW}$ grants, particularly competitive grants. However, some of the programs are funded by other sources as well, such as the Fragile Family 
project, which targets young fathers. Programs must operate within the constraints of overall budgets and special financial and eligibility requirements of the various funding sources.

These programs are each serving a relatively small number of participants, but provide intensive client-focused services for special target groups. Most of the programs had served between 100 and 200 participants by mid-2000. Within the WtW eligibility criteria, some of the programs target specific types of NCPs, for example, homeless veterans, incarcerated parents about to be released, parolees and probationers, or fathers under the age of 25 .

\section{GETTING NCPs TO PARTICIPATE}

Recruitment is a critical program design feature and a challenge for programs serving lowincome NCPs. For most of these programs, recruitment is one of the most difficult implementation challenges. The population is difficult to identify and hard to reach. When contacted, many NCPs are uninterested, or averse to participating, usually because they distrust programs that might be affiliated with child support enforcement agencies or the corrections system.

Programs use a combination of outreach and recruitment strategies and do not rely only on receiving participant referrals. Most of the programs establish formal and clear procedures to receive direct referrals from other agencies (e.g., child support enforcement programs, courts, and correctional facilities). In addition, many use mass mailings, public service announcements, neighborhood canvassing with literature and brochures, and presentations at community events and organizations. To build their base of participants, most programs work very hard to establish and maintain trust within the low-income community.

Programs generally adopt a "carrot-and-stick" approach. These programs primarily rely on voluntary participation by some or all of their NCPs. Nevertheless, some of the programs have strong mandatory features that bring parents into the program in the first place. Courts can require a person to participate in a program, for example, as a condition of parole or as part of a child support enforcement action. Even the programs that are highly mandatory, though, provide individualized employment and job retention services along with supportive services and case management.

- Positive incentives. The services available through the programs are the most common incentive for participating--primarily the employment services, but also transportation assistance, vouchers for work-related expenses, and other support services. Some programs are able to help get child support payment orders modified or to arrange for relief from payment arrearages. Programs that provide these options find them useful for encouraging both recruitment and ongoing participation.

- Requirements and sanctions. In mandatory programs, sanctions usually take the form of a threat of incarceration or child support collection activity and are most likely to be imposed through the courts, child support enforcement agencies, or correctional systems. 


\section{FULL RANGE OF SERVICES IN COMPREHENSIVE PROGRAMS}

All these programs conduct some type of employability assessment. Employment information (job history, skills, and vocational interests) is collected, along with some personal and family information. Staff may also assess health, reading and math ability, interpersonal skills, and self-esteem, either through case interviews or by administering a formal test or other instrument. In all of the programs, participants are required to sign personal responsibility contracts outlining their obligations in the program (specifically to participate in employment services, establish paternity, and pay child support).

Programs use two basic approaches for providing case management: a single case manager or a team of specialists. Staff feel that NCPs need "comprehensive" and "intensive" case management services; therefore, program staff often have small caseloads or share case management responsibilities among multiple staff or even with other agencies.

Employment preparation and postemployment services are the core program activities. Most of these programs focus on moving NCPs into jobs quickly and provide support services necessary to maintain employment.

- Job search and job readiness assistance are the primary employment services in these programs. Job search assistance is primarily provided through individualized, one-on-one meetings with program staff, but a few programs with somewhat more participants hold group job readiness workshops. Job search services are provided primarily under contract by community-based organizations with experience serving disadvantaged people (although not necessarily NCPs), although some programs provide services themselves. Contracting allows programs to draw on the expertise of different organizations and to serve NCPs with special needs (e.g., substance abuse problems and homelessness). Under both arrangements, NCPs can be referred to existing job search services provided at the Employment Service or One-Stop Career Centers.

- Some programs offer pre-employment education, vocational training, or on-the-job training, but participation in these services by NCPs is low. NCPs are interested in finding unsubsidized employment quickly (in part because of their need to pay child support) and are much less interested in job training or school.

- All these programs consider postemployment job retention services a key program element. To promote job retention, these programs continue to provide assistance to the NCPs once they find a job, usually by contacting the person at least monthly. There is less focus on career advancement and upgrading skills.

Parenting and relationship services are not a priority in all programs, but most provide access to some type of assistance. A few of the programs place a strong emphasis on parenting, improving access and visitation, and improving relationships with the other child's parents. In these programs, the services are fully integrated into the program model-primarily through 
regularly scheduled peer support sessions and individual counseling sessions. Parenting and relationship issues are not as central in other projects, although most address them as they arise through individual counseling sessions or referrals to parenting workshops and mediation services. A few incorporate parenting issues and instruction into other workshops that dealt more broadly with work readiness. Because NCPs generally do not have a good understanding of the child support enforcement system, some programs also systematically worked with participants on child support issues-often with designated staff from the child support enforcement agency.

Given the extent of employment barriers faced by low-income NCPs, most of these programs make specialized services available to participants through referrals to other organizations with expertise in the appropriate area. Most programs offer referrals for substance abuse problems, mental health issues, housing assistance, and anger management.

\section{CONCLUSION}

- A variety of public and private organizations can establish and operate programs for low-income NCPs. Programs for NCPs can be provided through a variety of different structural models, bringing together widely varying local partnerships and services. Because each locality operates within a different service environment and economy and serves a different clientele, no single model is necessarily preferable, nor is there a presumptive agency that should be the lead administrative entity.

- Programs can benefit from collaboration and coordination among agencies. This is a population with many problems-personal, legal, and employment-related. No single agency is likely to have the expertise and experience to address the wide combination of issues and problems. The availability of WtW funds helped to provide an impetus for bringing local agencies together for a common purpose: improve employment outcomes so that NCPs can better fulfill their responsibilities to pay child support and take a more active role in the lives of their children.

- Recruitment is a critical challenge and a major component of programs serving NCPs. For many NCPs, this can be a first step in improving their employment and earnings potential, but programs must gain their trust. While the expanded eligibility criteria in the $1999 \mathrm{WtW}$ amendments significantly broadened the pool of eligible participants and eased recruitment difficulties, these efforts continue to require constant attention, effort, and resources. Programs that are most successful in recruiting participants use multiple outreach and recruitment approaches, with particular attention to developing referral arrangements with other agencies serving large number of NCPs.

- A combination of positive inducements and pressures may prove more successful than either a completely voluntary program or a harshly punitive program. Involving both the child support agency and the courts-which can provide both "carrots and sticks" for participation-appears to be important for addressing both recruitment and program retention. Most programs used a mix of both positive (child 
support payment options, comprehensive program services) and negative incentives (threat of incarceration) to encourage participation. Once NCPs are participating, though, individualized employment and support services provided by professional staff with small caseloads are important.

- Helping NCPs understand and negotiate the child support enforcement system may be an important program service. Based on discussions with program staff, many low-income NCPs lack accurate information about the child support system, including how payments reach the children and how special payment plans can be arranged. While the programs in this study did not consistently emphasize this issue, some designated staff to assist participants on these issues-reportedly in a less adversarial way than traditional child support agency staff.

- Programs that provide employment-related services to low-income NCPs should ensure that a range of services is available to address the varied problems of these people and their families. NCPs are interested primarily in obtaining a job quickly. However, other employment and support services can improve their long-run economic status, earnings, and child support payment. Ongoing case management, counseling, and job placement assistance can improve job retention and ensure an effective transition to a new job. Job training and education activities could complement regular employment and improve skills. Some NCPs also may need a range of other support services in order to sustain regular employment and fulfill their parenting responsibilities. These services include mental health or substance abuse treatment, child care or transportation assistance, legal services, and housing assistance. 


\section{INTRODUCTION}

The role of noncustodial parents (NCPs) in the lives of low-income families has received increased attention from policymakers and program administrators in recent years. Increasing the level of child support that NCPs pay to children in low-income households is viewed as an important element in the range of policies designed to reduce the extent and depth of poverty and welfare dependency among children. However, research shows that about one-quarter of all NCPs do not pay child support because they are poor themselves and cannot afford to support their children without further impoverishing themselves or their families. ${ }^{1}$ This has led to increased efforts to boost the employment and earnings of these parents by encouraging them to participate in employment and training programs, and thereby increase their ability to provide financial support for their children and play more active roles in their lives.

The Welfare-to-Work (WtW) Grants Program, authorized under the Balanced Budget Act of 1997, is a primary vehicle for states and localities to provide employment, training, and other support services to NCPs, as well as hard-to-serve welfare recipients. WtW, with $\$ 3$ billion in federal funds, was enacted to complement the major welfare reform provisions authorized in 1996 under the Personal Responsibility and Work Opportunity Reconciliation Act (PRWORA), particularly the Temporary Assistance for Needy Families (TANF) block grant. The WtW grants complement TANF in that these funds are specifically designated for work-related activities and not for cash welfare payments. In addition, WtW funds target specific groups: the least employable welfare recipients and low-income noncustodial parents, including those with

\footnotetext{
${ }^{1}$ Mincy, R., and E. Sorensen. "Deadbeats and Turnips in Child Support Reform." Journal of Policy Analysis and Management, vol. 17, no. 1, pp. 44-51, 1998.
} 
children on or eligible for welfare or other types of public assistance. ${ }^{2}$ While services to NCPs were included in the initial legislation, changes made in 1999 to the WtW eligibility criteria increased the emphasis on NCPs as a key population to be served under this program.

From initial passage of the $\mathrm{WtW}$ legislation, enthusiasm about the possibility of serving NCPs was very high, with many states indicating that some or all of their state WtW dollars would be targeted at NCPs and a number of the organizations applying for and receiving grants indicating that NCPs would be part of their target populations. But based on anecdotal reports and the low numbers of NCPs actually served, ${ }^{3}$ implementation of such programs seemed more difficult than first envisioned. These implementation difficulties appeared consistent with reports of slow start-up by non-WtW programs serving NCPs, such as the Office of Child Support Enforcement Responsible Fatherhood Demonstration projects. ${ }^{4}$

This study examines the strategies that 11 purposively selected WtW grantees used to design their programs and recruit participants, including some of the mid-course corrections needed to improve services and client intake. It also summarizes lessons that can be learned from these efforts-lessons that are applicable to the larger community of workforce development and social services agencies which would like to be more pro-active in serving low-income noncustodial parents. This study was undertaken to provide field-based information to WtW state and community-based grantees and other programs interested in serving low-income NCPs

${ }^{2}$ See Section B for more information on the WtW target groups.

${ }^{3}$ Perez-Johnson, I., and A. Hershey. Early Implementation of the Welfare-to-Work Grants Program: Report to Congress. Princeton, NJ: Mathematica Policy Research, Inc., 1999.

${ }^{4}$ Pearson, J., N. Thoennes, D. Price, and J. Venohr. Office of Child Support Enforcement Responsible Fatherhood Programs: Early Implementation Lessons. Denver, CO: Center for Policy Research and Policy Studies, Inc., 2000. 
on how some WtW grantees had successfully managed to design and implement a program addressing the employment and other service needs of NCPs.

For this study, "success" is measured solely by programs' reported ability to recruit participants and deliver services. It is important that the reader recognize that this study is not an evaluation of WtW grantees' effectiveness in service delivery, employment placements, payment of child support, or improved father-child relationships. Information in the report is based on visits to the sites-no outcome information was gathered during this study and no analysis was conducted on program effectiveness. However, the findings from this study are important because there can be no improvement in outcomes for NCPs and their families unless programs can recruit participants and provide services.

\section{A. ISSUES FACING LOW-INCOME NONCUSTODIAL PARENTS}

While it is important to recognize the diversity of this population, low-income noncustodial parents are disproportionately poorly educated minorities with limited job opportunities. Studies have shown that, while many low-income NCPs have some work experience, many work intermittently and for low wages. ${ }^{5}$ Lack of stable and well-paying employment among lowincome NCPs is due to several factors, including lack of education and job skills, the decline in blue-collar jobs historically available to noncollege-educated men, discrimination, and a lack of

${ }^{5}$ Martinson, K. Serving Noncustodial Parents Through Welfare-to-Work Grants: Labor Market Characteristics, Employment Barriers, and Service Strategies. Washington, DC: The Urban Institute, 1998; and Sorenson, E. Low-Income Noncustodial Fathers: Who Are They and What Are States Doing to Assist Them in Their Effort to Pay Child Support? Washington, DC: The Urban Institute, January 1997. 
social networks among this population. ${ }^{6}$ In addition, many low-income NCPs have criminal records and substantial legal problems that prevent them from securing employment. ${ }^{7}$

Lack of stable employment clearly limits the ability of NCPs to pay child support. One study estimates that 60 percent of NCPs who do not pay child support are limited by income, education, high rates of institutionalization, or intermittent employment history. ${ }^{8}$ These NCPs have become known within the child support community as "dead broke" rather than "dead beat."

The child support system itself also establishes some disincentives for noncustodial parents to find work and make child support payments. ${ }^{9}$ When a child receives TANF, under federal law, the custodial parent on welfare must assign her rights to child support to the state. This means that most formal child support payments reimburse state and federal welfare costs, rather than go to the family (unless child support payments exceed the size of the welfare grant). ${ }^{10}$ In

${ }^{6}$ Martinson, 1998.

${ }^{7}$ Doolittle, F., et al. Building Opportunities, Enforcing Obligations: Lessons for Child Support Reform from the Parents' Fair Share Pilot Phase. New York, NY: Manpower Demonstration Research Corporation, 1998.

${ }^{8}$ Office of the Inspector General. The Establishment of Child Support Orders for LowIncome Noncustodial Parents. Washington, DC: U.S. Department of Health and Human Services, 2000.

${ }^{9}$ Reichert, Dana. Broke But Not Deadbeat: Reconnecting Low-Income Fathers and Children. Washington, DC: National Conference of State Legislatures, 1999.

${ }^{10}$ Prior to the passage of PRWORA, all states were required to pass-through the first $\$ 50$ per month of child support. Under PRWORA, states can choose whether to pass-through child support to the family or to retain the funds. Currently, less than half the states have a child support pass-through. See State Policy Re: Pass-Through and Disregard of Current Month's Child Support Collected for Families Receiving TANF-Funded Cash Assistance at http://www.clasp.org/pubs/childenforce/child_support_enforcement.htm. 
addition, orders are generally not modified quickly when the noncustodial parent becomes unemployed, which makes it difficult for NCPs to meet payment obligations and results in rapid accumulation of child support debt (or arrearages).

Several studies have documented that low-income men living apart from their children are often outside the social service and workforce development systems in the United States. ${ }^{11}$ Much of the social safety net has been structured around custodial parents and children, such as welfare assistance, including TANF (formerly the Aid to Families with Dependent Children program $[\mathrm{AFDC}]$ ) and Medicaid. Adult-based sources of support for education and training, such as Pell Grants and the Job Training Partnership Act (JTPA) program, ${ }^{12}$ serve low-income men and women, but often have not been able to enroll the hard-to-serve noncustodial fathers attached to poor custodial mothers. And even if served by these programs, there was no explicit connection made between the education and employment services being delivered and lowincome men's responsibilities as fathers. ${ }^{13}$

${ }^{11}$ Edin, K., L. Lein, and T. Nelson. Low Income, Non-Residential Fathers: Off-Balance in a Competitive Economy, An Initial Analysis. Washington, DC: U.S. Department of Health and Human Services, 1998, available at http://fatherhood.hhs.gov; and Johnson, E., A. Levine, and F. Doolittle. Fathers' Fair Share. New York, NY: Russell Sage Foundation, 1999.

${ }^{12}$ The Workforce Investment Act (WIA), enacted in 1998, replaced the JTPA program.

${ }^{13}$ An early exception was the Parents' Fair Share (PFS) demonstration program operated in seven sites around the country, which focused on increasing noncustodial parents' employment rates, earnings, and level of support provided to their children. This program-which was rigorously evaluated using a random assignment design in seven sites-provided employment services and enhanced child support enforcement to noncustodial parents with children receiving cash assistance. Noncustodial parents identified as being behind in their child support payments due to unemployment were ordered by the courts to participate in the program. The evaluation of this program showed mixed results. Across all sites, a referral to the PFS program increased the percentage of noncustodial parents who paid child support. There was also an increase in the average amount of child support paid in two sites. The program was moderately successful at increasing earnings among more disadvantaged fathers and had little effect on the earnings of more-employable fathers. See Martinez, J., and C. Miller. Working and Earning: The Impact of 
Beginning with the passage of PRWORA, which increased the flexibility states have in spending federal and state welfare funds ${ }^{14}$ and provided funding through the Office of Child Support Enforcement to increase parenting opportunities for NCPs through access and visitation grants to states, there has been increased interest in providing services to low-income NCPs. This interest in helping low-income fathers meet their responsibilities and the recognition of the need for additional services targeted to this population led to the inclusion of noncustodial fathers as a target group under WtW in the Balanced Budget Act of 1997 and the expansion of the eligibility criteria in the $\mathrm{WtW}$ amendments of 1999 (see discussion below).

\section{B. OVERVIEW OF THE WELFARE-TO-WORK GRANTS PROGRAM}

Under the WtW program, the federal government distributed \$3 billion in fiscal years 1998 and 1999 to help move hard-to-employ welfare recipients and noncustodial parents into jobs. Three-quarters of the funds were allocated to states based on a formula; one-quarter was distributed competitively based on applications submitted to the Department of Labor. Both formula and competitive grants target the same populations and can be used for the same types of activities. Some WtW funds may still be available to provide services to NCPs. As of July 2000 about $\$ 700$ million in federal $\mathrm{WtW}$ funds have been expended, leaving an unexpended balance of approximately $\$ 2$ billion. Grantees, under both the state formula and competitive programs

(continued)

Parents' Fair Share on Low-Income Fathers' Employment, New York, NY: Manpower Demonstration Research Corporation, 2000; and Doolittle, F. et al. The Kansas City Concerned Parent Program and the Los Angeles County Non-Custodial Parent-to-Work programs included in this report are based on the PFS model.

${ }^{14}$ A Guide to Funding Services for Children and Families Through the Temporary Assistance for Needy Families (TANF) Program. Washington, DC: U.S. Department of Health and Human Services, 1999. Available at http://fatherhood.hhs.gov. 
have at least until February 2001 and potentially through September 2002, depending on the date of original award, to use their funds.

WtW Eligibility Requirements for NCPs. The WtW legislation originally specified that both the formula and competitive grants must be used to fund services for the hardest-to-employ welfare recipients and noncustodial parents, although recent amendments have substantially broadened targeting requirements (especially for NCPs). (See Appendix B for a summary of the WtW amendments.) As originally enacted, the law required that at least 70 percent of the funds be used for:

1. Long-term TANF recipients or recipients who are within one year of reaching the TANF time limit and who also have two of three legislatively specified barriers to employment: no high school diploma or GED and low reading or math skills, substance abuse problems, or "poor work history"

2. Noncustodial parents who have two of the same three legislatively specified barriers to employment and have a child with a custodial parent or (in the case of a child-only case) a child who is a long-term TANF recipient or is within one year of reaching the TANF time limit

3. A person with two of the three barriers to employment (described above) but no longer receiving TANF, as a result of federal or state-imposed time limits

Under the original law, up to 30 percent of the funds could be used for TANF recipients or NCPs who have "characteristics associated with long-term welfare dependency," such as teenage parents, persons with poor work history, or high school dropouts. WtW funds could be used to serve the targeted groups of custodial parents on TANF, NCPs, or both the custodial and noncustodial parents together.

${ }^{15}$ The WtW regulations define "poor work history" as having worked no more than 13 consecutive weeks full-time in unsubsidized employment in the prior 12 months. 
As the WtW grants program was implemented, evidence accumulated quickly that the eligibility criteria were slowing enrollment and limiting participation. ${ }^{16}$ These concerns led to enactment in 1999 of amendments to the WtW eligibility criteria, which made it easier for both TANF recipients and NCPs to qualify for services. ${ }^{17}$ The amendments left intact the requirement that 70 percent of WtW funds be spent on a defined category of participants, but allowed NCPs to qualify if they met the following three conditions: (1) they are unemployed or underemployed, or are having difficulty making child support payments; (2) their minor children are receiving or eligible for TANF, or received TANF in the past year, or are receiving or are eligible for assistance under the Food Stamp, Supplemental Security Income (SSI), Medicaid, or the State Children's Health Insurance Program (SCHIP); and (3) they enter into a personal responsibility contract under which they commit to cooperating in establishing paternity, paying child support, and participating in services to improve their prospects for employment and paying child support. $^{18}$

WtW-Allowable Activities. WtW funds can be used for a range of activities designed to move eligible custodial parents and NCPs into employment, with an emphasis on jobs that have the potential for increasing future earnings. The funds can be used broadly for employmentrelated activities, including job readiness training/workshops; job placement assistance; on-the-

${ }^{16}$ Perez-Johnson, I., et al. Further Progress, Persistent Constraints: Findings from a Second Survey of the Welfare-to-Work Grants Program. Princeton, NJ: Mathematica Policy Research, Inc., 2000.

${ }^{17}$ The amendments to the WtW law went into effect in January 2000 for those receiving a $\mathrm{WtW}$ competitive grant and in July 2000 for formula grantees.

${ }^{18}$ The amendments removed the requirement that long-term TANF recipients exhibit additional barriers to employment. TANF recipients are eligible under the amended criteria if they have received assistance for at least 30 months, are within 12 months of reaching a time limit, or have exhausted their TANF benefits as a result of time limits. 
job training; community service or work experience; job retention services and other postemployment services; and a range of support services. Grantees are allowed substantial flexibility in designing $\mathrm{WtW}$ strategies geared to the needs of each participant and local labor market conditions.

The amendments also allow WtW funds to be used for pre-employment vocational education and job training for up to six months (under the original law, WtW funds could not be utilized for stand-alone job training or education). These funds can also be used for training or education once a person has begun work, either as a postemployment service in conjunction with work or as a work-based activity. Finally, WtW funds can be used for community service or work experience jobs, which include subsidized employment in the public, nonprofit, and forprofit sectors, as well as traditional on-the-job training.

Data Access and Confidentiality. The original law contained no provisions on data access, and program operators encountered difficulties in obtaining the data they needed to determine eligibility of NCPs. This led to amendments that give state child support enforcement agencies the authority to share information with Private Industry Councils (PICs, or local workforce investment boards) for the purposes of identifying and contacting NCPs about participation in the $\mathrm{WtW}$ program. The amendments also require that procedures be established for safeguarding privacy. ${ }^{19}$

\section{RESEARCH METHODS}

This study is designed to provide a current "snapshot" of programs serving noncustodial parents under the WtW program. Programs from eight states (including some in the same city)

\footnotetext{
${ }^{19}$ See Action Transmittal \#00-08 at www.acf.dhhs.gov/programs/cse/cseats_c.htm for more information on this provision.
} 
were purposively selected to illustrate a range of potential models and approaches to providing services for NCPs. Exhibit I-1 lists the programs selected for this study. ${ }^{20}$ Though most WtW programs serving NCPs are new and typically serve small numbers of NCPs, in selecting sites we sought programs that were fully operational and that served 100 or more NCPs. ${ }^{21}$ In the types of projects selected, we sought variation according to the following dimensions: geographic location (regions of the country, urban/rural), (2) subpopulations of NCPs served, (3) sponsoring agencies and types of collaborating partners, and (4) program models/approaches. The programs included in this study operated under both the original provisions and the amendments, although some programs were just beginning to implement the changes at the time of our site visit.

Information for the study was collected primarily through one- and two-day site visits conducted between May and July 2000. ${ }^{22}$ We talked with managers and line staff from the key partners in the program, including (as appropriate) the lead organization, the workforce development organization, employment service providers, the child support enforcement agency, and the courts. The discussions covered such topics as program goals/objectives, implementation process and challenges, outreach and recruitment, intake and assessment,

${ }^{20}$ Section II of this report provides some details on the basic characteristics of the selected programs.

${ }^{21}$ The two exceptions were the LA Veterans Program and the Nevada Business Services. These were smaller programs that provided interesting program designs and served very disadvantaged populations.

${ }^{22}$ Because Yakima, WA, is included in the larger WtW evaluation, information from this site was collected through phone interviews and from site visits conducted as part of a separate WtW study. 


\section{Exhibit I-1: Programs Included in WtW Noncustodial Parent Study}

\begin{tabular}{|c|c|}
\hline Program/Location & Program Description \\
\hline $\begin{array}{l}\text { Dekalb Fatherhood } \\
\text { Connection } \\
\text { Decatur, GA }\end{array}$ & $\begin{array}{l}\text { Community-based organization is lead agency, responsible for } \\
\text { employment and other support services. Participants are } \\
\text { referred from child support agency and recruited from } \\
\text { community. }\end{array}$ \\
\hline $\begin{array}{l}\text { Full Employment Council's } \\
\text { Concerned Parent Program } \\
\text { (CCP) } \\
\text { Kansas City, MO }\end{array}$ & $\begin{array}{l}\text { Workforce board provides employment and other support services. } \\
\text { Participants are referred from child support agency and recruited } \\
\text { from community. }\end{array}$ \\
\hline $\begin{array}{l}\text { Houston Works } \\
\text { Houston, TX }\end{array}$ & $\begin{array}{l}\text { Individuals facing threat of incarceration due to unpaid child support } \\
\text { can opt to participate in the program and are referred by the courts. } \\
\text { Services are contracted out and provided by several organizations } \\
\text { and agencies. }\end{array}$ \\
\hline $\begin{array}{l}\text { Institute for Responsible } \\
\text { Fatherhood and Family } \\
\text { Revitalization (IRFFR) } \\
\text { Milwaukee, WI }\end{array}$ & $\begin{array}{l}\text { One of seven programs in a national nonprofit organization. Strong } \\
\text { emphasis on one-on-one and peer group counseling sessions. The } \\
\text { primary goal is to connect noncustodial parents (NCPs) with their } \\
\text { children and improve parenting skills. }\end{array}$ \\
\hline $\begin{array}{l}\text { LA County Noncustodial } \\
\text { Parent-to-Work Program } \\
\text { Los Angeles, CA }\end{array}$ & $\begin{array}{l}\text { Provides employment services to NCPs who are in child support } \\
\text { arrears and unemployed. Operated by the workforce board with the } \\
\text { District Attorney's Office providing referrals. }\end{array}$ \\
\hline $\begin{array}{l}\text { LA Veterans in Progress } \\
\text { Los Angeles, CA }\end{array}$ & $\begin{array}{l}\text { Targets NCPs who are both homeless and veterans. Residential } \\
\text { program with most employment and support services provided on } \\
\text { site. }\end{array}$ \\
\hline $\begin{array}{l}\text { Milwaukee Private Industry } \\
\text { Council (PIC) Program } \\
\text { Milwaukee, WI }\end{array}$ & $\begin{array}{l}\text { Collaborative of five specialized community-based organizations } \\
\text { (e.g., substance abuse, mental health, legal issues) under contract } \\
\text { with PIC to provide employment and other services to NCPs. }\end{array}$ \\
\hline $\begin{array}{l}\text { Minneapolis FATHER } \\
\text { Project } \\
\text { Minneapolis, MN }\end{array}$ & $\begin{array}{l}\text { Lead agency is nonprofit community-based organization. Strong } \\
\text { emphasis on parenting. Employment services are contracted out to } \\
\text { other organizations, and individuals are recruited from community. }\end{array}$ \\
\hline $\begin{array}{l}\text { Nevada Business Services } \\
\text { Las Vegas, NV }\end{array}$ & $\begin{array}{l}\text { Workforce board has contracts with two nonprofit agencies to } \\
\text { provide employment and other services to NCPs. One provider } \\
\text { targets male NCPs while the other serves incarcerated female NCPs } \\
\text { who will be released in the near future. }\end{array}$ \\
\hline $\begin{array}{l}\text { Wisconsin Department of } \\
\text { Corrections NOW Program } \\
\text { Milwaukee, WI }\end{array}$ & $\begin{array}{l}\text { Targets NCPs on probation and parole, with most employment and } \\
\text { support services provided through the five W-2 agencies in } \\
\text { Milwaukee. }\end{array}$ \\
\hline $\begin{array}{l}\text { Yakima SHARE Program } \\
\text { Yakima, WA }\end{array}$ & $\begin{array}{l}\text { Individuals facing threat of incarceration due to unpaid child support } \\
\text { can choose to participate in the program and are referred by the } \\
\text { Prosecuting Attorney's Office. Employment services are provided } \\
\text { by a number of community-based organizations. }\end{array}$ \\
\hline
\end{tabular}


employment services, linkages with the child support agency, postemployment services, parenting skills instruction, and case management practices.

Two important limitations of this study should be noted. First, our observations are based on site visits in just eight communities. While some broader conclusions are warranted based on similar findings across several sites, the study results are not nationally representative. Second, this is a descriptive study that focuses on implementation experiences of selected sites. It is intended to provide information on program design and development and recruitment strategies. It is not possible from the information gathered during the site visits to draw conclusions about the effectiveness of particular programs or approaches in increasing employment, earnings, and child support payments or improving relationships with family members.

\section{STRUCTURE OF THE REPORT}

The sections that follow present key study findings from visits conducted to each program. Section II provides an overview of the basic design and structure of initiatives, including types of sponsoring agencies and partners, funding sources, project goals/objectives, participation levels, types of target populations served, and an overview of key implementation issues. The roles of the workforce development agencies and the child support enforcement agencies are highlighted in this section. Section III examines recruitment and basic incentives for participation-what turned out to be critical elements in getting noncustodial parents into program services. Section IV assesses the wide variety of services available to participants at the NCP programs visited, including intake and assessment, case management, employment and postemployment services, parenting services, and other support services. Section V provides conclusions and implications of the study, including "lessons learned" from the project sites about assisting NCPs in securing employment, paying child support, and being a better parent. Short summaries of each program 
visited are attached in Appendix A and a summary of the WtW amendments is provided in Attachment B. 


\section{PROGRAM DESIGN AND CHARACTERISTICS}

The sites included in this study demonstrated that a variety of local agencies can work together to sponsor programs that assist noncustodial parents in enhancing their employability and their prospects for paying child support and being a better parent. The sections that follow provide an overview of the types of agencies that sponsor initiatives and of their partners, funding sources, project goals/objectives, participation levels, and types of populations served. Exhibit II-1 provides a cross-site comparison of key dimensions discussed in this chapter.

\section{A. SPONSORING AGENCIES AND PARTNERSHIPS WITH OTHER ORGANIZATIONS}

Different Types of Local Agencies Took the Lead in Sponsoring NCP Projects. Six of the 11 projects visited had as their lead agency a local workforce development organization. Because all projects received $\mathrm{WtW}$ funds and focused on employment, it is not surprising that local workforce development agencies took the lead in a number of sites. Projects led by local workforce development boards that also administered Workforce Investment Act (WIA) programs were located in Houston (Houston Works), Los Angeles (the Los Angeles County PIC), Las Vegas (Nevada Business Services), Yakima (the Tri-County Workforce Development Council), Milwaukee (the PIC of Milwaukee County), and Kansas City (the Full Employment Council).

In the five other sites, all of which also have some level of involvement of local workforce development organizations, other types of local organizations played the lead role. For example, in Milwaukee (where we visited a total of three NCP programs), one initiative (Project NOW) was sponsored by the Wisconsin Department of Corrections (DOC), a second by the Institute for Responsible Fatherhood and Family Revitalization (IRFFR), a nonprofit 
Exhibit II-1: Key Background Features of Noncustodial Parent Programs

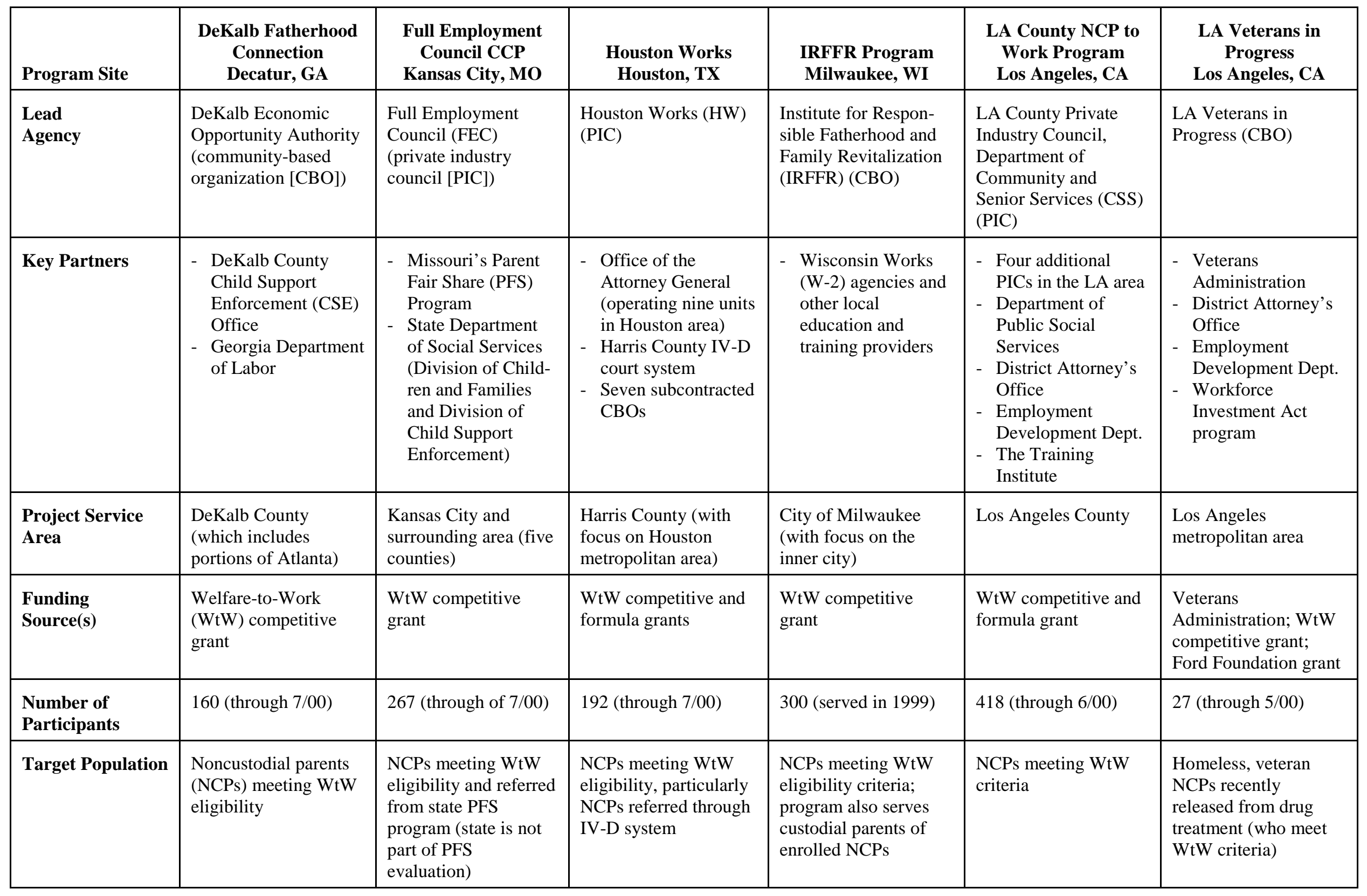


Exhibit II-1 (continued)

\begin{tabular}{|c|c|c|c|c|c|}
\hline Program Site & $\begin{array}{c}\text { Milwaukee PIC Program } \\
\text { Milwaukee, WI }\end{array}$ & $\begin{array}{c}\text { Minneapolis FATHER } \\
\text { Project } \\
\text { Minneapolis, MN }\end{array}$ & $\begin{array}{c}\text { Nevada Business Services } \\
\text { Las Vegas, NV }\end{array}$ & $\begin{array}{c}\text { WI Dept. of Corrections } \\
\text { NOW } \\
\text { Milwaukee, WI }\end{array}$ & $\begin{array}{c}\text { Yakima Share Program } \\
\text { Yakima, WA }\end{array}$ \\
\hline Lead Agency & PIC of Milwaukee & $\begin{array}{l}\text { Way-to-Grow (WTG) } \\
(\mathrm{CBO})\end{array}$ & $\begin{array}{l}\text { Nevada Business Services } \\
\text { (NBS) (PIC) }\end{array}$ & $\begin{array}{l}\text { Wisconsin Department of } \\
\text { Corrections (DOC) (state } \\
\text { agency) }\end{array}$ & $\begin{array}{l}\text { Tri-County Workforce } \\
\text { Development Council } \\
\text { (PIC) }\end{array}$ \\
\hline Key Partners & $\begin{array}{l}\text { - Five subcontracted } \\
\text { agencies: Human } \\
\text { Services Triangle, } \\
\text { Wisconsin Correctional } \\
\text { Services, United } \\
\text { Migrant Opportunity } \\
\text { Services, New Concepts, } \\
\text { and Curtis and } \\
\text { Associates } \\
\text { - Five W-2 agencies } \\
\text { - State child support } \\
\text { enforcement agency }\end{array}$ & $\begin{array}{l}\text { - Neighborhood } \\
\text { Employment Council } \\
\text { (coalition of eight } \\
\text { subcontracted CBOs) } \\
\text { - State and Hennepin } \\
\text { County Child Support } \\
\text { Enforcement Office } \\
\text { - Minneapolis } \\
\text { Employment \& Training } \\
\text { Program (Minneapolis } \\
\text { Workforce Board) }\end{array}$ & $\begin{array}{l}\text { - Two subcontracted local } \\
\text { CBOs: Nevada Partners } \\
\text { and Services Project } \\
2000 \\
\text { - Nevada State Welfare } \\
\text { Division }\end{array}$ & $\begin{array}{l}\text { - WI Department of } \\
\text { Workforce Development } \\
\text { - Private Industry Council } \\
\text { of Milwaukee } \\
\text { - Five W-2 Agencies }\end{array}$ & $\begin{array}{l}\text { - DHS Division of Child } \\
\text { Support } \\
\text { - Prosecuting Attorney's } \\
\text { Office } \\
\text { - Three community-based } \\
\text { organizations }\end{array}$ \\
\hline Project Service Area & Milwaukee County & Minneapolis & $\begin{array}{l}\text { Clark, Lincoln, Nye, and } \\
\text { Esmeralda counties, with } \\
\text { focus on Las Vegas }\end{array}$ & Milwaukee County & $\begin{array}{l}\text { Yakima, Kittitas, and } \\
\text { Klickitat counties (all are } \\
\text { rural counties) }\end{array}$ \\
\hline Funding Source(s) & WtW competitive grant & $\begin{array}{l}\text { WtW competitive grant; } \\
\text { Ford Foundation grant }\end{array}$ & $\mathrm{WtW}$ formula grants & $\begin{array}{l}\text { Governor's WtW } 15 \\
\text { percent discretionary funds; } \\
\text { DOC grant }\end{array}$ & $\begin{array}{l}\mathrm{WtW} \text { formula and } \\
\text { competitive grants }\end{array}$ \\
\hline $\begin{array}{l}\text { Number of } \\
\text { Participants }\end{array}$ & 460 (through 6/00) & $100($ thru $5 / 00)$ & 70 (through 6/00) & 130 (through 6/00) & 185 (through 9/00) \\
\hline Target Population & $\begin{array}{l}\text { NCPs meeting WtW } \\
\text { eligibility; subcontractors } \\
\text { specialize in serving } \\
\text { subpopulation (e.g., } \\
\text { offenders, substance } \\
\text { abusers, mentally ill) }\end{array}$ & $\begin{array}{l}\text { NCPs who meet WtW } \\
\text { criteria; more recently } \\
\text { focusing on young NCPs }\end{array}$ & $\begin{array}{l}\text { NCPs meeting WtW } \\
\text { eligibility; Services Project } \\
2000 \text { targets female NCPs } \\
\text { offenders at correctional } \\
\text { facility }\end{array}$ & $\begin{array}{l}\text { NCPs on probation or } \\
\text { parole and soon-to-be- } \\
\text { released inmates in } \\
\text { minimum security prisons } \\
\text { meeting WtW criteria }\end{array}$ & $\begin{array}{l}\text { NCPs meeting WtW } \\
\text { eligibility, particularly } \\
\text { NCPs referred through IV- } \\
\text { D system }\end{array}$ \\
\hline
\end{tabular}


organization headquartered in Washington, DC. ${ }^{23}$ Nonprofit organizations have the lead in three other localities:

- Way-to-Grow, a community-based organization that provides social services to lowincome mothers and children, sponsored the initiative in Minneapolis

- LA Vets, which specializes in services for homeless veterans, led the effort at one NCP project in Los Angeles

- The Dekalb Economic Opportunity Authority (EOA), a nonprofit community action agency in Atlanta, led the Fatherhood Connection program.

One lesson that emerges from this study is that, while workforce development organizations are perhaps a natural sponsor for NCP programs (especially with WtW formula funding being distributed through local workforce development boards), a variety of other public and nonprofit organizations can take the lead in serving NCPs. Each locality is different-there is no single model for development of initiatives for NCPs, and no particular agency that must lead such initiatives.

\section{Programs Brought Together a Wide Range of Partners to Meet the Varied Needs of}

Low-Income NCPs. As shown in Exhibit II-1, the NCP projects we visited brought together a wide range of local partners. Nearly all projects involved partnerships with five or more organizations, and in several sites partnerships extended to ten or more organizations. Collaboration was a critical component in all the sites visited, because no single organization could bring to bear all the services required to meet the varied needs of low-income NCPs. In some instances, partners were brought to initiatives to strengthen and expand recruitment efforts, particularly in cases where lead organizations experienced difficulties with identifying and

${ }^{23}$ Using WtW competitive grant funds, IRFFR has mounted responsible-fatherhood programs to serve low-income, noncustodial fathers in several other locations (Cleveland, $\mathrm{OH}$; Nashville, TN; San Diego, CA; Washington, DC; and Yonkers, NY). 
enrolling NCPs. Partners were also brought in to provide needed documentation for eligibility (for example, TANF agencies to assist with determining eligibility of NCPs under WtW rules). Other partners were brought into initiatives because of the direct client services they were able to provide, such as workforce development organizations (for job placement, skills upgrading, and retention assistance); courts and child support agencies (for information about child support arrearages and paternity establishment, as well as to modify payments and visitation); and a wide range of social service agencies (for transportation assistance, housing assistance, vocational rehabilitation, substance abuse and mental health treatment, and a range of other support services). Box II-A provides examples of the different types of partnerships in the programs we visited.

\section{Among the Most Important Partnerships Were Those Between the Workforce} Development and Child Support Enforcement Agencies. Given the focus on serving NCPs and making them employable, two of the most common partners were local workforce development agencies and child support enforcement entities. As shown on Exhibit II-2, seven of the projects featured partnerships with child support enforcement agencies—-where the agency played some role in the program.

The role of the child support enforcement agency in the programs for NCPs varied among the sites. An important role in several of the programs was to provide direct referrals to the NCP program—either from the agency or from the court. As discussed in more detail in Section III, the programs in Houston (see Box II-A) and Yakima obtain referrals from the courts, while referrals were made by the child support enforcement agency in Dekalb, Kansas City, and the Los Angeles County NCP-to-Work programs. 


\section{Box II-A}

\section{Examples of Partnerships in NCP Programs}

- Minneapolis FATHER Project. The lead agency in this initiative is Way-to-Grow (WTG), a nonprofit organization operating programs for mothers and children. Among the key linked agencies under the Welfareto-Work (WtW) program are the workforce development agency serving Minneapolis (the Minneapolis Employment and Training Program), the Neighborhood Employment Council (a coalition of eight nonprofit organizations providing employment services), and the local and state child support enforcement offices. This initiative, and the partners involved, grew out of an earlier and ongoing initiative led by WTG under Ford Foundation's Partners for Fragile Families (PFF) Initiative. WtW funding came along after the partners involved in PFF had already come together and developed the design for PFF. These partners viewed WtW as an opportunity to expand the resources available for serving NCPs in Minneapolis and to build on efforts underway as part of the PFF initiative. The relationship between WTG and the state child support enforcement agency was sufficiently strong enough that the state applied for and received a federal waiver from the Office of Child Support Enforcement at the U.S. Department of Health and Human Services, which provided federal funding support for the PFF demonstration.

- Houston Works. Although Houston Works, a workforce development agency, is the lead organization in terms of providing funding and overseeing this NCP project, the child support enforcement system helped to shape this initiative and plays a critical role in providing a steady stream of NCPs in need of employment services. The Office of the Attorney General (OAG) for the State of Texas, which operates nine Child Support Enforcement Units in the Houston area, played a key role in the development of this project. In the years leading up to the initiative, the OAG had been looking for ways to improve systems for collection of child support (including prevention of arrearages, alternatives to jail, and more father-friendly approaches), but lacked resources needed to implement new strategies. The Harris County court system also played an instrumental role in the development of the project. Three local judges agreed to court-ordered participation in the Houston Works project as an alternative to jail on child support orders. They also arranged for an NCP case manager (from Houston Works or one of its subcontractors) to be present at the courts each day the court is in session. In terms of providing direct services for NCPs referred through the courts, Houston Works subcontracts with seven local human services agencies to provide assessment, case management, employment and training services, post-placement services, support services, and referral to a range of other support services: Educational Learning and Enrichment Center (ELEC), SEARCH Homeless Project, DSU Training Institute, Houston Community College, Employment and Training Centers (ETC), Goodwill Industries, and Refugee Services Alliance (RSA).

- Wisconsin NOW Program. The Wisconsin Department of Corrections (DOC), Division of Community Correction has taken the lead role in project design, startup, and ongoing administration of NOW, which targets NCPs on probation or parole. DOC identifies participants and has assigned ten probation and parole agents to case manage NOW participants throughout their involvement in the program. The Wisconsin Department of Workforce Development, which has overall responsibility for administration of employment, training, and welfare programs in the state (including welfare reform and the JTPA program), assisted with the design of the initiative and determines WtW eligibility for potential NOW participants. DOC contracts with five Wisconsin Works (W-2) agencies to provide case management, employment, training, parenting, and other support services for NOW participants. The five W-2 agencies are Employment Solutions of Milwaukee (affiliated with Goodwill Industries); United Migrant Opportunity Services; Opportunities Industrialization Center of Greater Milwaukee; YW Works; and Maximus. 
Exhibit II-2: Role of Child Support Enforcement (CSE) Agency in NCP Programs

\begin{tabular}{|c|c|c|c|c|}
\hline Program/Location & $\begin{array}{l}\text { CSE Agency } \\
\text { is Partner }\end{array}$ & $\begin{array}{l}\text { Referral from } \\
\text { CSE Agency } \\
\text { or Courts } \\
\end{array}$ & $\begin{array}{c}\text { Flexible CSE } \\
\text { Policies for } \\
\text { Participants } \\
\end{array}$ & $\begin{array}{c}\text { Designated } \\
\text { CSE Staff } \\
\text { for Program } \\
\end{array}$ \\
\hline $\begin{array}{l}\text { Dekalb Fatherhood } \\
\text { Connection } \\
\text { Decatur, GA } \\
\end{array}$ & Yes & Yes & No & Yes \\
\hline $\begin{array}{l}\text { Full Employment Council's } \\
\text { Concerned Parent Program } \\
\text { (CCP) } \\
\text { Kansas City, MO }\end{array}$ & Yes & Yes & Yes & Yes \\
\hline $\begin{array}{l}\text { Houston Works } \\
\text { Houston, TX } \\
\end{array}$ & Yes & Yes & No & Yes \\
\hline $\begin{array}{l}\text { Institute for Responsible } \\
\text { Fatherhood and Family } \\
\text { Revitalization (IRFFR) } \\
\text { Milwaukee, WI }\end{array}$ & No & No & No & No \\
\hline $\begin{array}{l}\text { LA County Noncustodial } \\
\text { Parent-to-Work Program } \\
\text { Los Angeles, CA }\end{array}$ & Yes & Yes & Yes & Yes \\
\hline $\begin{array}{l}\text { LA Veterans in Progress } \\
\text { Los Angeles, CA }\end{array}$ & Yes & No & Yes & Yes \\
\hline $\begin{array}{l}\text { Milwaukee PIC Program } \\
\text { Milwaukee, WI }\end{array}$ & Yes & No & No & No \\
\hline $\begin{array}{l}\text { Minneapolis FATHER } \\
\text { Project } \\
\text { Minneapolis, MN }\end{array}$ & Yes & No & Yes & Yes \\
\hline $\begin{array}{l}\text { Nevada Business Services } \\
\text { Las Vegas, NV }\end{array}$ & No & No & No & No \\
\hline $\begin{array}{l}\text { Wisconsin Department of } \\
\text { Corrections NOW Program } \\
\text { Milwaukee, WI }\end{array}$ & No & No & No & No \\
\hline $\begin{array}{l}\text { Yakima SHARE Program } \\
\text { Yakima, WA }\end{array}$ & Yes & Yes & Yes & Yes \\
\hline
\end{tabular}


Another role played by the child support enforcement agency was to provide additional incentives for participation. This role is discussed more extensively in Section III. Some programs—including those in Kansas City, Minneapolis, and Yakima-offered flexible child support payment options for program participants including establishment of reduced payment agreements and reestablished default orders.

In several of the programs, the child support enforcement agency designated specific staff to work with the NCP program. The role of these staff varied, although as discussed in Section IV an important role for some of them was to assist the NCP in understanding the child support system and ensuring that child support payments were made-but reportedly in a less adversarial way than the traditional child support enforcement agency staff. For example, in Dekalb, a liaison from the child support agency assisted the program's case managers in resolving any issues that may have prevented the NCP from finding or keeping a job and on ensuring that child support payments were made. In Minneapolis, designated case workers at the child support enforcement agency worked with participants on arranging child support modifications and (if necessary) establishing paternity and orders.

Staff in some child support enforcement program partners said that their agency's participation in the NCP program required or represented a paradigm shift in agency culture and values. Several child support enforcement staff we interviewed indicated that the concept of assisting NCPs delinquent in child support was not only new for them, but also ran counter to their traditional mission and procedures. These officials noted that child support enforcement agencies are usually judged by the amount of child support they collect and the size of annual increases. As one interviewee stated, "Our goal is compliance, not casework."

In some cases, motivation for trying a new "helping" approach was purely pragmatic: it was based on the realization that some NCPs simply could not pay child support, and that tactics 
traditionally used to deal with them, such as incarceration and suspension of driver's licenses, failed to address their lack of income and often worsened prospects for employment and payment of child support. Hence, at least as a first step, it made sense for child support enforcement agencies to refer unemployed or underemployed NCPs to a program that could improve chances for job placement, upgrading of wages, and job retention.

\section{B. PROJECT SERVICE AREA}

Programs Mostly Served NCPs within Urban Areas. All the programs we visited served NCPs in urban areas. Three of the 11 programs served multi-county areas in and around an urban area that included surrounding suburban areas and adjoining rural areas. The Nevada Business Services program served a four-county area (coinciding with the agency's workforce development area) that was spread across the southern half of the state, although most participants came from Las Vegas. The other two programs with multi-county service areas were Yakima (which served a primarily rural three-county area that included Yakima) and Kansas City (which served a five-county area that included Kansas City). Generally, the study programs served a single county (six sites) or focused on a particular city (the Minneapolis site) or an inner-city area within an urban area (the Milwaukee IRFFR site).

\section{FUNDING SOURCES}

Funding Sources Significantly Affected Program Design and Partnerships. All the programs included in this study were funded either wholly or partly through the WtW grants program. Funding sources were important, because each program had to work within the constraints of overall funding, and each funding source had related program requirements. For example, WtW funding brought fairly specific targeting requirements with respect to eligibility and imposed restrictions on the types of allowable services (see Section I for details). The 
narrowness of the 70 percent targeting requirement under $\mathrm{WtW}$ initially constrained the pool of noncustodial parents who could qualify under the program, which reportedly hampered the recruitment efforts of many programs (see discussion below).

Most Sites Relied upon WtW Competitive Grant Funds. Nine of the 11 programs visited used WtW competitive grants to fund their projects (see Exhibit II-1). Four of the programs used WtW formula funds, and three programs (Houston Works, the Los Angeles County Noncustodial Parent-to-Work Program, and the Yakima SHARE Program) used both competitive and formula grant funds. One program, the Wisconsin DOC's NOW Program, used WtW 15 Percent Discretionary funding for the NCP initiative.

Sites Sometimes Blended WtW Funds with Other Funding. When programs focused on a particular population, they were sometimes able to leverage funding from other sources that also had an interest in serving that population. For example, the LA Vets Program and the Milwaukee DOC received additional funding from the Veterans Administration and the Wisconsin DOC, respectively. The Minneapolis Fatherhood Project, a site in a national demonstration project (under the Partners for Fragile Families initiative) sponsored by the Ford Foundation and the Department of Health and Human Services, was able to supplement its foundation resources with both a WtW competitive grant and federal child support matching funds.

One lesson that emerges from our visits is that $\mathrm{WtW}$ funds provided the seed money to bring partners together to design and implement NCP initiatives. The grant funds also helped leverage funds from other sources (e.g., foundations and federal, state, and local agencies). In addition, through collaboration with other agencies, NCP projects accessed additional services for NCPs at little or no cost, which helped to extend grant funds and expand the numbers of NCPs that could be served. 


\section{PARTICIPATION LEVELS AND TARGET GROUPS SERVED}

Study Programs Served Relatively Small Numbers of Participants. Overall, the programs included in the study operated on a small scale. ${ }^{24}$ From the time they first began receiving WtW funds (generally only in 1999) through the time of our site visits (in summer 2000), most programs had served between 100 and 200 participants. The Milwaukee PIC (460 noncustodial parents served through June 2000) and the Los Angeles County PIC (418 through June 2000) had served the largest number of NCPs; next in size were the IRFFR program in Wisconsin (estimated at about 300 served in 1999) and the Kansas City Concerned Parent Program (CPP, 267 participants). The smallest of the programs was LA Vets, which had enrolled and served 27 NCPs. As noted above, the smallest programs such as LA Vets focused on serving a specific, disadvantaged population of NCPs.

The scale of some of the programs was affected by a number of factors, particularly difficulties recruiting NCPs (discussed in detail in Section III), as well as constraints in the level of funding. However, the program size also reflects that many NCPs received services for an indefinite period of time. Under $\mathrm{WtW}$ rules, programs can continue to serve individuals indefinitely (as long as the program has funding). This enabled programs to continue to provide NCPs with postemployment services, help with finding a new job or upgrading to a higherpaying job, and assistance with support services. As discussed in Section IV, most sites had not established specific rules for when an individual was terminated from the program.

${ }^{24}$ The sites provided somewhat varying estimates of participation levels over different time periods, so it was difficult to compare participation levels across sites. Some provided estimates of the number of NCPs served from program inception to the time of our visit while others provided current levels of participation. 


\section{Because of Their Locations, Study Programs Served High Concentrations of Inner-}

City African Americans. Given their primary funding source, all the programs in this study targeted noncustodial fathers who met the WtW eligibility criteria, primarily low-income men with children receiving welfare or other means-tested benefits. The programs did not target particular racial or ethnic groups, but because they often operated in urban and inner-city areas, their caseloads included high proportions of minority clients: African Americans (in ten sites) and Hispanics (in two sites).

Several Programs Targeted Special Groups of NCPs, Including Offenders, ExOffenders, Veterans, and Homeless People. Within the WtW eligibility requirements, programs sometimes targeted a specific subgroup of noncustodial parents. For example, the LA Vets program targeted a particularly hard-to-serve population: NCPs who were both veterans and homeless. The programs in Milwaukee (Project NOW) and Nevada (Services Project 2000) focused on ex-offenders on parole and probation and those who were incarcerated (but soon to be released). After initially focusing broadly on NCPs who met the WtW eligibility criteria, the Minneapolis program, because of its participation in a Ford Foundation project, shifted to a focus on younger fathers (under age 25) who did not have paternity established (but who still met the WtW criteria).

NCPs Faced Many of the Same Barriers to Employment as Custodial Parents, but Had Fewer External Supports. Many NCPs had limited education and skill levels and lacked stable work experience. In this way, the employment barriers that NCPs faced were similar to those faced by custodial parents receiving cash assistance-a group that some program operators generally had more experience in serving. However, in several ways, NCPs presented challenges different from those that arise in serving TANF custodial parents. Because of pressures to pay child support and make ends meet, many NCPs came to programs strongly motivated to find jobs 
quickly and hold onto them. In fact, several program operators noted that if programs could not rapidly find jobs for participants, NCPs were likely to lose interest in participating in other services and drop out of programs. Staff also reported that while NCPs were somewhat more likely than TANF recipients to have some level of work experience and occupational skills, they often faced one or more serious barriers to employment. For example, program staff reported that NCPs were more likely than custodial parents receiving TANF to be ex-offenders and/or to have substance abuse problems. Both these factors often limited job opportunities, particularly chances to obtain higher-paid employment.

Noncustodial parents also lacked eligibility for programs such as TANF and Medicaid, which provided ongoing support for many low-income custodial parents. Program operators also reported that NCPs often had a limited understanding of the child support enforcement system, which tended to compound their difficulties with the system and contribute to rapid accumulation of child support arrearages. Use of enforcement tools within the child support system could result in additional barriers to employment. For example, the loss of a driver's license because of nonpayment of support could complicate the effort to secure and keep employment.

\section{E. PROGRAM GOALS}

All Study Programs Had a Strong Emphasis on Employment and Job Retention. Because WtW (with its emphasis on "work first" approaches) funded all the programs included in this study, job placement and retention were primary goals (see box for several illustrations of program goals and objectives). 


\section{Box II-B}

\section{Illustration of Types of Program Goals in NCP Programs}

- Dekalb Fatherhood Project. The primary goal of the Dekalb Fatherhood Project is to find jobs for the noncustodial parents (NCPs). Staff at all levels consistently explained that the thrust of their program is "work first." Employment, either full- or part-time, is the emphasis in order to increase child support payments. Once the NCP is working, staff also focus on promoting other "self-enhancement" activities, such as education and training (done concurrently with work), and on addressing a range of other issues, including substance abuse, mental health problems, and parenting issues.

- Institute for Responsible Fatherhood and Family Revitalization. The central emphasis of the IRFFR project is on reconnecting NCPs with their children and improving parenting skills. At the core of the project is a belief that attitude change leads to other positive consequences, such as greater involvement with children, payment of child support, paternity establishment, and long-term employment. An important goal of the program is to resolve relationship issues and disputes between the noncustodial and custodial parents, so that the NCP can become actively involved financially and emotionally with the children.

- LA Veterans in Progress. With support from the Veteran's Administration, this program was established in 1993 to meet a serious service gap for homeless veterans in the Los Angeles area. Homeless veterans who successfully completed substance abuse or alcohol programs had nowhere to live and no one to provide continued support for them to reenter the world of work. The goals of the original program were to help homeless veterans become self-sufficient and, when capable, participate fully in the labor market and achieve residential stability and continued sobriety. With additional support from the WtW grants program, the program seeks to assist homeless veteran fathers already being served in the VIP program obtain employment, improve their relationship and parenting skills with their children, stop the cycle of fatherlessness, and improve their payment of child support.

Program operators indicated that noncustodial parents also had a strong preference for program services that would help them find a well-paying job quickly. This was because many NCPs came to programs unemployed, underemployed, or, even if fully employed, living from check to check. If they were unemployed, they often did not qualify for unemployment benefits or had exhausted existing benefits. Typically, NCPs had little if any savings and had often accumulated some, often substantial, child support arrearages. They also had little in the way of support systems or others (e.g., a working spouse or family member) they could count on during extended periods of unemployment or time spent acquiring new skills in training programs. Periods of unemployment or underemployment generally caused them to fall further behind with 
child support payments in a battle to keep up with housing, food, and transportation expenses. In addition, NCPs often faced strong pressures from courts or child support enforcement agencies to find and keep jobs so they could make child support payments. Hence, participants (like program funders) had a strong preference for services that would help them land a job quickly (e.g., short-term job readiness workshops and one-on-one placement assistance).

While program staff clearly viewed job placement as their primary mission, most also placed a strong emphasis on job retention. A common problem NCPs faced-often one that leads to enrollment in the NCP program in the first place-is job loss and inability to maintain stable employment over an extended period. As discussed in greater detail in Section IV of this report, programs sought to enhance chances of long-term employment by providing participants with postemployment services: ongoing case management, troubleshooting of problems as they arose in the workplace and at home, assistance with transportation, referral to education and training for upgrading basic and job-related skills, and guidance toward a range of other supportive services.

Payment of Child Support Was Also an Important Goal of Most Programs. In addition to helping NCPs secure employment, most programs also had the goal of increasing the child support payments made by the NCP. Because stable employment was necessary for the consistent payment of child support, this goal generally complemented the employment focus of the programs. The goal of increasing child support payments was particularly strong in programs that were closely linked with the child support enforcement system, such as the Houston Works and the Yakima SHARE projects.

Some Programs Had Goals of Improving Parenting. A few programs blended goals of improving employability with those of building parenting skills and reconnecting NCPs with their children. For example, programs in Minneapolis (the Minneapolis FATHER Project) and 
Wisconsin (the IRFFR program) viewed increasing the involvement of NCPs in the lives of their children and building parenting skills as project goals on an equal footing with improving employment outcomes. While most other programs sought a general improvement in family and parenting situations, these two sites assigned these objectives particular priority. As discussed later in the report, staff in some other sites indicated a desire to add parenting or responsiblefatherhood programs in the near future. 


\section{GETTING NONCUSTODIAL PARENTS TO PARTICIPATE}

Recruitment, enrollment, and retention are critical if programs are to serve noncustodial parents. The programs involved in this study all found these to be their most challenging tasks. This section discusses two key elements for eliciting participation among noncustodial parents: (1) recruitment strategies to identify and enroll potential program participants, and (2) incentives (both positive and negative) that programs used. Exhibit III-1 provides an overview of key features of the recruitment approaches and incentives used by individual sites.

\section{A. RECRUITMENT AND OUTREACH STRATEGIES}

\section{Recruitment Proved to Be a Critical Program Component at All Sites, With Many of the Sites}

Struggling to Recruit NCPs. A key aspect of all the programs visited involved the extent to which they developed recruitment strategies to identify and inform potentially interested and eligible noncustodial parents about available services. For most sites, the recruitment of NCPs proved to be difficult. Programs had to work hard to build up their base of participants, even though most programs were relatively small, serving fewer than 200 NCPs. Programs used a variety of outreach methods, particularly linking with other agencies to obtain referrals.

Effective outreach and recruitment strategies are vital features of NCP programs. If programs are unable to identify and enroll eligible NCPs, even the most comprehensive and effective service delivery systems cannot succeed. If recruitment activities are not carefully tailored to the target group and well executed by project staff, they can be inefficient and costly. Nearly all programs included in this study struggled with recruitment right from the start, and had to change and fine-tune their recruitment methods and program "messages." None of the programs indicated that they were "swamped" by NCPs or that they could not adequately 
Exhibit III-1: Recruitment Methods and Incentives to Participation in NCP Programs

\begin{tabular}{|c|c|c|c|c|c|c|}
\hline Program Site & $\begin{array}{c}\text { Dekalb Fatherhood } \\
\text { Connection } \\
\text { Decatur, GA }\end{array}$ & $\begin{array}{l}\text { Full Employment } \\
\text { Council (FEC) CCP } \\
\text { Kansas City, MO }\end{array}$ & $\begin{array}{c}\text { Houston Works } \\
\text { Houston, TX }\end{array}$ & $\begin{array}{l}\text { IRFFR Program } \\
\text { Milwaukee, WI }\end{array}$ & $\begin{array}{l}\text { LA County NCP to } \\
\text { Work Program } \\
\text { Los Angeles, CA }\end{array}$ & $\begin{array}{l}\text { LA Veterans in } \\
\text { Progress } \\
\text { Los Angeles, CA }\end{array}$ \\
\hline $\begin{array}{l}\text { Outreach/ } \\
\text { Recruitment } \\
\text { Methods }\end{array}$ & $\begin{array}{l}\text { - Direct referrals from } \\
\text { Child Support } \\
\text { Enforcement (CSE) } \\
\text { agency } \\
\text { - } \text { Recruitment in } \\
\text { community through } \\
\text { program staff (teams } \\
\text { of case managers are } \\
\text { located in a local } \\
\text { community and } \\
\text { focus on } \\
\text { neighborhood } \\
\text { canvassing) } \\
\text { - Presentations at } \\
\text { prisons and other } \\
\text { programs, word of } \\
\text { mouth } \\
\text { - Communication } \\
\text { specialist } \\
\text { responsible for } \\
\text { developing } \\
\text { recruitment } \\
\text { materials }\end{array}$ & 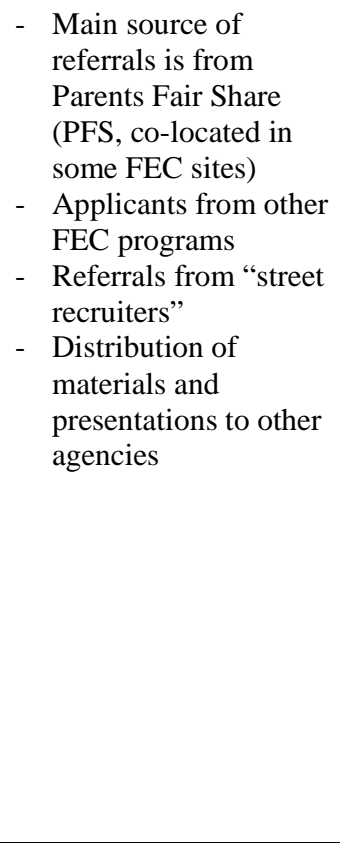 & $\begin{array}{l}\text { - Direct referrals } \\
\text { through CSE units } \\
\text { and IV-D courts } \\
\text { - "Reverse referrals" } \\
\text { through seven sub- } \\
\text { contracted agencies } \\
\text { - Other outreach } \\
\text { methods include } \\
\text { posters, brochures, } \\
\text { targeted mailings, } \\
\text { radio public service } \\
\text { announcements, word } \\
\text { of mouth }\end{array}$ & 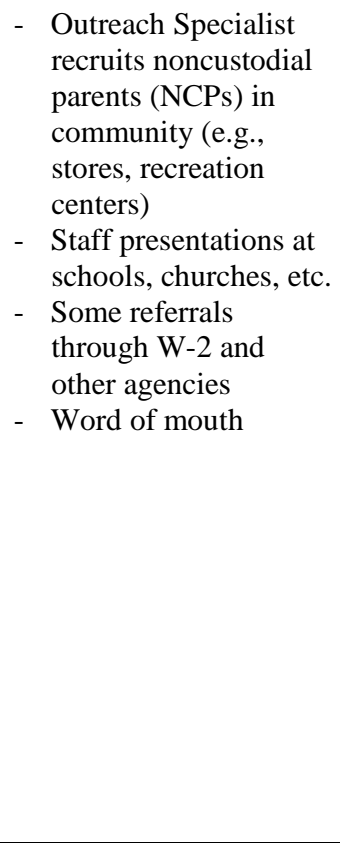 & $\begin{array}{l}\text { - Department of Public } \\
\text { Social Services } \\
\text { (DPSS) and District } \\
\text { Attorney's Office } \\
\text { provides lists of those } \\
\text { potentially eligible for } \\
\text { program } \\
\text { - Mailings and cold } \\
\text { phone calls are made } \\
\text { to those on list } \\
\text { - Posters advertising in } \\
\text { other program in other } \\
\text { county offices }\end{array}$ & $\begin{array}{l}\text { Maintains contacts } \\
\text { with over } 90 \text { county } \\
\text { agencies to identify } \\
\text { potential participants } \\
\text { (including DPSS, } \\
\text { prisons, and } \\
\text { rehabilitation groups) }\end{array}$ \\
\hline $\begin{array}{l}\text { Nature of } \\
\text { Participation }\end{array}$ & $\begin{array}{l}\text { Mandatory and } \\
\text { voluntary }\end{array}$ & Mandatory and voluntary & Mandatory and voluntary & Voluntary & Voluntary & Voluntary \\
\hline $\begin{array}{l}\text { Sanctions and } \\
\text { Incentives }\end{array}$ & $\begin{array}{l}\text { NCPs referred from } \\
\text { CSE can be issued } \\
\text { contempt citations } \\
\text { and arrested for not } \\
\text { participating } \\
\text { - Program services are } \\
\text { important incentive }\end{array}$ & 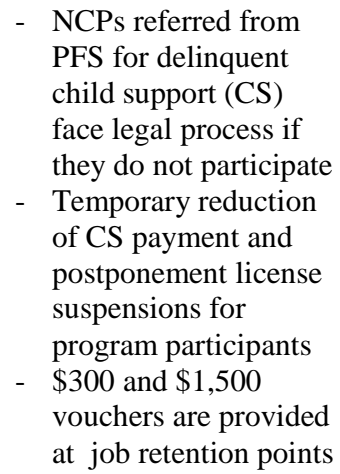 & $\begin{array}{l}\text { - NCPs referred from } \\
\text { CSE who do not } \\
\text { participate may face } \\
\text { incarceration } \\
\text { - Program services are } \\
\text { important incentive }\end{array}$ & $\begin{array}{l}\text { - Main incentive for } \\
\text { participation is } \\
\text { program services }\end{array}$ & $\begin{array}{l}\text { - Program services are } \\
\text { important incentive } \\
\text { - Accumulation of } \\
\text { arrearages can be } \\
\text { stopped }\end{array}$ & $\begin{array}{l}\text { - Program services are } \\
\text { important incentive } \\
\text { - Order and arrearage } \\
\text { payments can be } \\
\text { modified }\end{array}$ \\
\hline
\end{tabular}


Exhibit III-1 (continued)

\begin{tabular}{|c|c|c|c|c|c|}
\hline Program Site & $\begin{array}{c}\text { Milwaukee PIC Program } \\
\text { Milwaukee, WI }\end{array}$ & $\begin{array}{c}\text { Minneapolis FATHER } \\
\text { Project } \\
\text { Minneapolis, MN }\end{array}$ & $\begin{array}{c}\text { Nevada Business Services } \\
\text { Las Vegas, NV }\end{array}$ & $\begin{array}{c}\text { WI Dept. Of Corrections } \\
\text { NOW } \\
\text { Milwaukee, WI }\end{array}$ & $\begin{array}{c}\text { Yakima Share Program } \\
\text { Yakima, WA }\end{array}$ \\
\hline $\begin{array}{l}\text { Outreach/Recruitment } \\
\text { Methods }\end{array}$ & $\begin{array}{l}\text { - Direct referrals from } \\
\text { family courts, the } \\
\text { Children's First Initiative, } \\
\text { W-2 agencies, and } \\
\text { Wisconsin Dept. Of } \\
\text { Corrections (DOC) } \\
\text { - Five subcontracting } \\
\text { agencies conduct own } \\
\text { outreach, including } \\
\text { attending community } \\
\text { events, distributing } \\
\text { brochures about the } \\
\text { program, and media } \\
\text { advertising. }\end{array}$ & $\begin{array}{l}\text { Outreach methods include } \\
\text { posters, brochures, radio } \\
\text { and television advertising, } \\
\text { staff presentations at local } \\
\text { programs and } \\
\text { organizations, family } \\
\text { picnic, mass mailing to } \\
\text { CSE clients, and word of } \\
\text { mouth } \\
\text { - Referrals from employment } \\
\text { service providers }\end{array}$ & 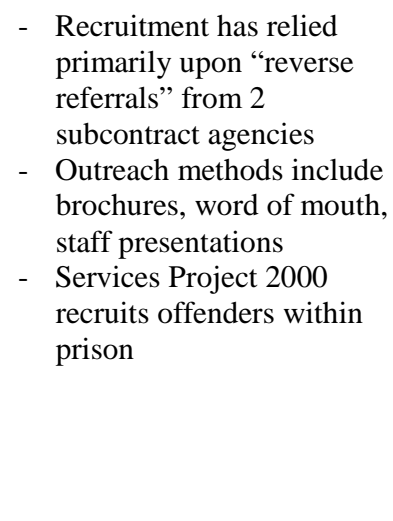 & $\begin{array}{l}\text { - Main source of referrals is } \\
\text { from DOC probation and } \\
\text { parole agents (main source } \\
\text { of referrals) } \\
\text { - Small number of "reverse } \\
\text { referrals" through W-2 } \\
\text { agencies } \\
\text { - Memos and presentations } \\
\text { to DOC probation and } \\
\text { parole agents to make them } \\
\text { aware of the program }\end{array}$ & $\begin{array}{l}\text { - Direct referrals from CSE } \\
\text { units and Prosecuting } \\
\text { Attorney's Office. } \\
\text { - Established a short-term } \\
\text { position to identify eligible } \\
\text { NCPs at the CSE office }\end{array}$ \\
\hline $\begin{array}{l}\text { Nature of } \\
\text { Participation } \\
\end{array}$ & Mandatory and voluntary & Voluntary & Voluntary & Voluntary & Mandatory \\
\hline $\begin{array}{l}\text { Sanctions and } \\
\text { Incentives }\end{array}$ & $\begin{array}{l}\text { - Individuals referred from } \\
\text { courts can face continuing } \\
\text { legal action for } \\
\text { nonparticipation } \\
\text { - Program services are } \\
\text { important incentive }\end{array}$ & $\begin{array}{l}\text { - Program services are } \\
\text { important incentive } \\
\text { - Child support payment } \\
\text { options for participants } \\
\text { including delay of CS } \\
\text { orders for } 90 \text { days, } \\
\text { modification of orders, } \\
\text { stopping interest on } \\
\text { arrearages, lifting penalties, } \\
\text { free paternity } \\
\text { establishment, waiving } \\
\text { birthing expenses }\end{array}$ & $\begin{array}{l}\text { - Main incentive for } \\
\text { participation is program } \\
\text { services }\end{array}$ & $\begin{array}{l}\text { Participation is voluntary, } \\
\text { but once enrolled } \\
\text { participation in NOW } \\
\text { activities becomes } \\
\text { mandatory (though } \\
\text { revocation of probation or } \\
\text { parole unlikely based } \\
\text { solely on non-compliance } \\
\text { with NOW project) } \\
\text { - Program services are } \\
\text { important incentive }\end{array}$ & $\begin{array}{l}\text { - NCPs who do not } \\
\text { participate may face } \\
\text { incarceration } \\
\text { - Child support payment } \\
\text { options include: payment } \\
\text { agreements for less than } \\
\text { current amount } \\
\text { (temporarily), } \\
\text { reestablishing default } \\
\text { orders, and possibly } \\
\text { waiving arrears } \\
\text { - Program services are } \\
\text { important incentive }\end{array}$ \\
\hline
\end{tabular}


serve those who were eligible. In fact, staff in most sites said they were constantly involved in recruitment and were looking for additional NCPs to serve.

\section{Programs Faced Challenges in Recruiting NCPs and Interesting Them in Program}

Services. Staff gave a variety of reasons and factors that accounted for their difficulties with recruitment of NCPs (see Box III-A for several specific illustrations of the problems encountered by sites in this study).

\section{Box III-A}

\section{Problems Experienced with Recruitment in NCP Programs}

- Kansas City Concerned Parent Program. Like other grantees, the Full Employment Council (FEC) experienced some early difficulties with recruitment and enrollment, in part because of the narrowness of the initial Welfare-to-Work (WtW) eligibility requirements and also in part because of reluctance of NCPs to participate or difficulties in obtaining needed eligibility information. For example, some NCPs could not provide Social Security numbers or sometimes even the last name of the custodial parent needed to determine the welfare status of the children. Sometimes custodial parents lived out of the area or even out of state. Broadening of the eligibility requirements has helped expand the pool of eligibles, and FEC now has access to information that does not require Social Security information. The project also found that special events were of limited value, which staff attributed at least in part to NCPs' wariness of "smoke-outs" or "sting" operations (events conducted by other agencies to attract NCPs and then make arrests for child support arrearages). Their link with Missouri's Parents' Fair Share program has proven to be a vital source of referrals, and over time FEC has been flexible enough to test and improve recruiting strategies. For example, the program is now using two young fathers as "street recruiters" to go out into the communities and neighborhoods to provide information to men and women who may need and qualify for program services.

- Wisconsin Department of Corrections NOW Program. This program relied at first on probation or parole officers to refer men from their caseloads, but enrollment was slow. Officers already had heavy workloads and lacked strong incentives to comb their caseloads for suitable referrals, since cases transferred from their caseloads to NOW officers would be replaced. Another factor was that many NCPs were not eligible for WtW services under the original eligibility criteria, often because the mothers of their children were no longer receiving TANF or were not long-term recipients. Some NCPs were reluctant to participate or failed to enter the program because they had already committed new offenses or feared that failing in NOW would result in revocation of parole or probation. 
First, unlike TANF recipients, NCPs have not traditionally been the focus of programs in the past, so many NCPs were simply not aware that programs existed for them. Many NCPs identified as potential candidates had never before been enrolled in social service or employment programs. Many potential recruits were difficult to reach and, when contacted, were either uninterested or even averse to participation. Site staff reported that some NCPs were distrustful of programs or agencies (particularly if programs were attached to child support agencies, the courts, or correctional systems). For example, some NCPs (especially those with large child support arrearages) were concerned that their involvement in programs might lead to garnishment of wages, loss of driver's licenses, or even imprisonment. Some NCPs feared that recruitment events might even be "sting" operations set up by local law enforcement agencies. In several sites, staff also reported that some NCPs were reluctant to open letters sent by welfare or child support agencies. Several administrators underscored the importance of building a track record and trust within the local community, because NCPs were not accustomed to accessing services and were often wary of programs linked or potentially linked to the welfare or child support enforcement system.

Second, because NCPs have not typically participated in other human services programs, it was often difficult for the program to find and link with other agencies that might be able to refer large numbers of individuals. Even those programs that were able to identify other agencies that served large numbers of NCPs (e.g., the IV-D court system, child support agencies, local initiatives aimed at youth, and the correctional system), found that some of these other agencies were not eager to partner or that the NCPs were not very interested in participating in another program.

Third, staff in most study programs reported that NCPs were interested primarily in securing a steady, well-paying job. In most locations the programs operated, economic conditions had 
been relatively good in recent years (with low unemployment and even labor shortages in some occupations). Depending upon an individual's job-specific skills and employer demand for a particular occupation, NCPs could secure relatively well-paying jobs quickly without outside assistance. Hence, favorable economic conditions ironically translated into less demand among NCPs for program services even though they might help improve their earnings in the long run.

Fourth, some NCPs had little or no desire to reconnect with the custodial parent or dependent children and so were not interested in pursuing services. Similarly, some custodial parents who might have information that could help recruit NCPs were uncooperative either because they did not want to be reconnected with the NCP or because they wanted to protect the NCP from being identified by child support enforcement agencies.

Fifth, at least initially (before Congress passed legislation simplifying the WtW eligibility criteria for NCPs), programs found it difficult to find NCPs that met the eligibility criteria (particularly the 70 percent criterion) or to obtain the necessary verification data. Fearing they might be audited in the future and have to pay back funds used for NCPs who did not meet the initial $\mathrm{WtW}$ eligibility criteria, programs were cautious in making sure they could document WtW eligibility before enrolling NCPs.

Finally, in addition to these constraints, some agencies either did not initially recognize the difficulties they might encounter in recruiting NCPs or failed to develop plans for conducting recruitment. Others did not allocate sufficient resources or staff, and some lacked experience conducting aggressive outreach efforts, particularly with regard to NCPs.

Program Design and Resources Affected Recruitment. The ways in which projects structured their outreach and recruitment depended upon a number of factors. Whether sites targeted specific NCP subpopulations (e.g., offenders, ex-offenders, or NCPs with arrearages) or sought to recruit all eligible NCPs often affected both the type and the scope of recruitment 
efforts. For example, programs such as those in Wisconsin (ex-offenders), Houston (NCPs involved with the IV-D system), and Nevada (soon-to-be-released female inmates) sought to establish referral arrangements with the courts and the correctional system. Other sites that more broadly targeted NCPs were more likely to conduct outreach activities in local neighborhoods and to use media advertisements and public service announcements (PSAs). Two programs, Kansas City and Dekalb, received referrals from state child support programs and also conducted their own outreach and recruitment activities.

Resources available and allocated to outreach efforts played a role in determining the structure and methods used. For example, some types of outreach were more expensive (e.g., media advertisement and sending staff into the local neighborhoods to conduct outreach) than others (e.g., making presentations to local agencies, relying on referrals from other agencies, and distribution of flyers/brochures). The extent to which programs were already established within their communities had some effect on the intensity of outreach needed and methods employed. Those agencies or programs that were the "new guys on the block" reportedly needed to work harder at recruitment. Finally, the willingness of other agencies to partner and success with regard to referring eligible NCPs affected the need for sites to conduct additional outreach. Those sites that could obtain a steady flow of referrals from other agencies had to conduct less outreach on their own.

Though Recruitment Strategies Emphasized Referrals from Other Agencies, Sites Employed a Variety of Other Strategies. Similar recruitment methods were used in most of the study programs, especially receiving referrals from other agencies and distributing flyers and program brochures. Exhibit III-1 provides a cross-site comparison of strategies employed including: 
- Direct Referrals from Other Agencies. This was a particularly important method for many programs. Both mandatory and voluntary programs looked to those agencies that served large numbers of NCPs-primarily the IV-D courts and correctional systems, but also substance abuse programs and homeless shelters - and sought to set up referral arrangements that would result in a direct flow of NCPs from these agencies. Setting up such arrangements often proved more difficult than expected. The referral arrangements between agencies had to be carefully monitored and refined over time to ensure that administrators and line staff in other agencies actually referred NCPs and that the referred NCPs actually showed up. Several examples of innovative agency referral methods are highlighted in Box III-B. Links to child support enforcement agencies and courts (for example, as in Houston Works site), as well as the correctional system (as in the Wisconsin DOC's Project NOW), which could provide access to large pools of potential recruits for NCP programs. If wellstructured, partnerships with the child support enforcement and correctional systems can provide NCP projects with a steady source of referrals.

- Distribution of Brochures/Flyers and Presentations at Other Local Human Services Agencies to Increase Public Awareness. Programs sought to reach NCPs either by making staff at other agencies knowledgeable about program offerings or by placing program literature where NCPs would see it. One important strategy that sites employed was to visit other agencies that served NCPs and to brief staff (individually or as a group) about available program services, eligibility, and how to refer NCPs to the program. Often program literature and brochures were left with other agency staff to be handed out to NCPs or displayed in other places that NCPs and their custodial parents were likely to frequent, such as: other social service programs, grocery stores, churches, local schools and training institutions, recreational facilities and playgrounds, public housing facilities, probation and parole agencies, and in IV-D courts. Some program staff made presentations at orientation sessions attended by NCPs or custodial parents (e.g., orientations held at prerelease centers for offenders, orientations for individuals served by one-stop career centers, orientations for TANF recipients, and workshops held by local fatherhood initiatives). In some sites, staff attended and/or set up booths at local job fairs and other community events, where they could distribute program literature and talk one-onone with potential program recruits.

- Use of PSAs on Radio and Television, and Paid Advertisements in Local Media. Some programs sought out opportunities for free PSAs on local radio and television stations. Local site administrators and staff also gave interviews to local television, radio, and newspaper reporters, which provided an opportunity to inform a wider audience of NCPs and custodial parents about available services. Some sites also paid for advertisements on local radio stations and in local newspapers. 
- Use of Mass Mailings Targeting NCPs and Custodial Parents. Some agencies (e.g., the Way-to-Grow project in Minneapolis and the Nevada Business Services in Las Vegas) mailed out letters about the program to carefully targeted groups of NCPs or custodial parents. However, several administrators noted that significant numbers of NCPs were reluctant to respond to mass mailing by public agencies (especially those closely linked to child support enforcement or welfare programs), which limited the success of mailings.

- Reliance on Word of Mouth. Programs also relied on word of mouth, particularly through former participants and community leaders. Because programs often targeted a specific community, this reportedly was one of the most effective ways of distributing information about the program and encouraging program participation. Hearing from a local church leader, friend, or relative that a program provided useful services (e.g., the program helped someone find a job or obtain improved visitation) was considered the most certain way to interest people.

- Neighborhood Recruiting. Several sites sent individual staff and case management teams into neighborhoods (the Dekalb Fatherhood Project and IRFFR) where potential recruits congregated, to distribute information about program services and conduct one-on-one recruitment. One program, the Concerned Parent Program (in Kansas City), sent two noncustodial fathers into neighborhoods as "street recruiters" to make informal contacts with potential recruits. These programs reported that the ability to interact one-on-one with fathers in their own neighborhoods and explain program services in some detail helped to begin to build trust and interest in participation.

Overall, program administrators and staff emphasized the importance of not underestimating the difficulties of attracting NCPs to programs. They noted that even if programs appeared to offer the range of services NCPs needed, staff must not assume that NCPs will be easy to find or that they will participate (even if pursued vigorously). Even programs in which recruits were threatened with incarceration if they failed to participate found it difficult to engage and keep NCPs in their programs. Difficulties sites experienced with recruitment stemmed from the problems discussed at the beginning of this section, particularly those related to getting the word out about program services to NCPs (who are not accustomed to being served by such initiatives) and building sufficient interest and trust in NCPs so they are willing to take the initial steps needed to access available services. 


\section{Box III-B \\ Illustrations of Recruitment Methods in NCP Programs}

- Minneapolis FATHER Project. This project used a multifaceted approach. First, they disseminated materials (primarily flyers and posters) to different agencies, including job banks, prenatal clinics, Temporary Assistance to Needy Families (TANF) offices, Women, Infants, and Children (WIC) offices, child support offices, family court, probation officers, and other community-based organizations. Second, Way-to-Grow (WTG) staff conducted presentations about the program for staff at numerous agencies, including TANF, corrections, and the courts. They also used newspaper and radio ads in publications and stations used by the target population. (The radio ads were particularly effective.) WTG also sponsored a community barbecue for families. While this barbecue resulted in the enrollment of just four dads, project staff thought it was very useful for getting the word out about the program. The child support enforcement office also did mass mailings to noncustodial parents (NCPs). Finally, now that the program is better known within the community, they find that word of mouth has become an increasingly important way in which NCPs learn about the program.

- Houston Works. Most recruitment for this project comes either under court order by IV-D Court Masters (judges) or through direct referral by Office of the Attorney General (OAG) staff from one of the nine Child Support Enforcement Units in Houston. Unemployed or underemployed NCPs that come before the IV-D judges for nonpayment of child support are court-ordered to report to Houston Works for orientation, assessment, and participation in employment services offered by the agency. The judges may use the program as an alternative to a jail sentence and require (as part of a compliance hearing) that NCPs report back to the court within 30 or 90 days on their participation in the program. If the NCP fails to report to Houston Works or fails to follow through on services available through the project, the IV-D judge will take this into consideration in the compliance hearing. The courtroom includes posters promoting the program, and the bailiff hands out brochures to NCPs about the program services and how to access them. In addition, the court has made available office space for the project so that Houston Works (or one of its subcontractors) can have a staff person available whenever the court is in session (Monday-Thursday from 9 AM to 2 PM). The judges indicate to NCPs that they must meet with the on-site staff person immediately upon completion of the hearing so they can be scheduled for orientation at Houston Works. Staff from the nine Child Support Enforcement Units also make referrals to the project, often as a result of negotiations over an initial child support order or failure to pay child support.

- Institute for Responsible Fatherhood and Family Revitalization. IRFFR Outreach Specialists recruit young fathers where they frequently gather in the community, including local stores, recreational centers, basketball courts, and playgrounds. The program office is located within the inner-city community it serves, and outreach specialists live within that same community. Additionally, fathers are recruited through staff presentations at schools, churches, and other gatherings of NCPs. IRFFR also provides information about the program to staff at other agencies and programs serving the community (including W-2 agencies and the Department of Corrections) and accepts referrals from these agencies. A significant proportion of NCPs are self-referrals, hearing about the program through word of mouth from friends, relatives, coworkers, and others in the community. 


\section{B. INCENTIVES TO PARTICIPATE}

\section{Most Study Programs Relied upon Voluntary Participation by Some or All}

Noncustodial Parents. Programs varied in terms of whether participation was mandatory or voluntary, as well as in the types of incentives offered to participate. As shown in the cross-site comparison earlier in Exhibit III-1, among the 11 programs visited, six had voluntary program participation, four featured a combination of voluntary or mandatory participation (generally depending upon the source of the referral), and one only involved mandatory participation.

In our discussions, site administrators and staff indicated that encouraging participation and reducing attrition from programs were among the most challenging issues they face. A "carrotand-stick" approach appeared to offer the greatest potential for getting NCPs into programs and keeping them engaged. Mandatory programs included the threat of some type of sanctioning if the individual did not participate in services or if he dropped out before completing the project. Sanctions, which usually took the form of incarceration or strict child support collections, were most likely to be imposed through the courts, child support enforcement agencies, or correctional systems. Program services and flexibility on child support payments for program participants (offered by a few sites) were the primary positive incentives used by the study sites to encourage participation. It is important to note that even mandatory programs also offered some positive inducements.

The one study site that featured mandatory participation for all NCPs was the Yakima SHARE Program, which was a collaborative effort of several agencies (including the local workforce development board, the local child support enforcement office, and the prosecuting attorney). With a primary goal of ensuring that NCPs became employed and paid their child support, this program relied for recruitment entirely upon the child support agency and the prosecuting attorney's office. These agencies referred NCPs who were unable to find work on 
their own to the SHARE program, under threat of incarceration if the person did not participate. Most NCPs choose to participate, and few were jailed. Administrators believed that the leverage of the court's involvement and the realistic threat of jail served as an important motivator to NCPs. However, this program also had what it viewed as important "carrots." For example, the child support agency, working with the courts, could provide a number of breaks on child support: (1) establishment of payment agreements for less than the current amount for a temporary period, (2) reestablishment of payment agreements for default orders that were originally incorrect (default orders or orders completed when the noncustodial parent was not present), and (3) the possibility of waiving arrearages.

Five sites we visited featured mandatory participation for some participants and voluntary participation for others, usually on the basis of the referral source of the NCP. The Houston Works and the Wisconsin DOC are two examples of projects that included both elements. In the case of the Houston Works site, the major source of referrals was the IV-D system. NCPs were ordered by IV-D judges to attend the program or face jail time. A compliance hearing was typically held 90 days after the court order was issued to determine if conditions were met. Failure to cooperate with Houston Works and to pay child support would likely result in jail time (for up to six months) for the NCP. However, subcontracted agencies to Houston Works under the initiative were also encouraged to conduct recruitment efforts on their own, and NCPs coming to the program through these subcontracted agencies did so voluntarily. In the case of the Wisconsin DOC program, NCPs on probation or parole were given the choice of enrolling in Project NOW. However, once the NCP decided to enroll, attendance in program activities became mandatory. Noncompliance could be a reason for revocation of probation or parole, though usually revocation would result for failure to participate in Project NOW along with some other infraction of the terms of probation or parole. 
Finally, about half the sites featured voluntary enrollment on the part of all program participants. Several of these programs were operated by workforce development agencies (e.g., the Los Angeles PIC, Nevada Business Services, and the PIC of Milwaukee County) and tended to have outreach and recruitment activities that were either apart from the child support enforcement system or included substantial numbers of referrals that did not come through it. An example of a voluntary approach to participation was IRFFR (in Milwaukee). IRFFR, which embraces the view that a father has the inner capacity to solve his own problems, recruited NCPs who had a strong desire to make changes in their lives and reconnect with their children. 


\section{PROGRAM SERVICES}

At the core of the programs for noncustodial parents are the services to assist participants in moving to employment and improving their relationships with their families. These programs use a range of approaches to help participants achieve these goals. This section describes how these programs performed intake and assessment, managed NCP cases, provided employmentrelated services, assisted with parenting and relationship matters, and delivered other types of support or ancillary services.

\section{A. INTAKE AND ASSESSMENT}

The first step to enrolling a noncustodial parent in a program was to have eligibility determined, based on the $\mathrm{WtW}$ criteria. In some cases, a referral agency made this determination (particularly if the child support enforcement agency was responsible for the referral); in others, the lead agency determined eligibility (often in coordination with other agencies with necessary information on the NCP). If the $\mathrm{NCP}$ was determined to be eligible, an assessment was completed.

If a person was not eligible for the WtW program, most agencies made referrals to another program in the community or referred the person to a one-stop career center. Some staff stressed the importance of providing some kind of service to every NCP who came in the door, both because they were often very needy and because developing trust and support in the community was important to gain additional referrals, recruits, or walk-ins.

Assessments Generally Were Conducted through One-on-One Interviews. In all of the study programs, employment goals and prior work history were the focus of the assessment interview. A range of other issues, such as family circumstances, parenting education, 
transportation and housing, health and behavioral problems, and pending legal actions, were also discussed in greater or lesser detail depending on the goals of the program. Some programs administered the Test of Adult Basic Education (TABE) to gauge the reading and math skills of some or all applicants. Other formal assessment tools were used less often. One program (Services Project 2000, a subcontractor to Nevada Business Services in the Las Vegas site) used a formal screening instrument to assess drug and alcohol abuse, and a second program (LA Vets) required drug tests because all participants were former drug or alcohol abusers who had agreed to remain drug free during the program. The result of the assessment was generally an employment plan (in some sites referred to as an individual service strategy) outlining the steps the participant would take to find a job.

Study Programs Required Participants to Sign a Personal Responsibility Contract. In all the programs, participants were required to have personal responsibility contracts. Personal responsibility contracts outline the conditions and requirements of the program. By signing the contract, the participant agrees to accept these requirements. These contracts were required by the $\mathrm{WtW}$ amendments, although several of the programs we visited used contracts even before the amendments were in place. As specified in the $\mathrm{WtW}$ amendments, the contracts generally required NCPs to participate in employment services, establish paternity, and pay child support.

The personal responsibility contracts were generally completed as part of the upfront assessment, after the participant received a general orientation to the program, the participant's employment and family background were discussed, and an employment plan had been agreed to. Overall, program staff experienced little difficulty in implementing the personal responsibility contracts. In some instances, participants were nervous about signing these contracts, but in general, program staff found that participants were willing to agree to the requirements—even in sites serving a voluntary population. In many cases, the contract was part 
of a package of other forms the participant was required to sign, such waivers giving permission for agencies to provide information needed for eligibility or to share information with each other.

\section{B. CASE MANAGEMENT}

Program staff, often referred to as case managers, use various strategies to monitor, direct, counsel, or assist participants in their efforts to obtain employment and address other issues. A case manager is generally responsible for ongoing contact with the participant, including conducting the assessment, providing employment and job referrals, coordinating supportive services, and documenting employment or related activities. In some programs, the case manager may be more of a coordinator than a counselor and may manage only certain activities or limited aspects of a client's case.

\section{Programs Used Two Basic Approaches for Providing Case Management Services.} Several of the programs included in the study-IRFFR, Nevada Business Services, and Yakima SHARE_-provided all case management services through a single staff person. In these programs, one staff person was responsible for intake and assessment, the provision of job search services, and all follow-up and monitoring activities. This approach offered the advantage of having all the service needs of the noncustodial parent addressed through a single point of contact.

Other programs used a team approach with multiple staff-usually two but sometimes more-each of whom had responsibility and expertise in different areas. In some programs, such as those in Minneapolis and Houston, case management was provided by a team from multiple agencies, while the Dekalb and Kansas City programs assigned multiple staff from the same agency. As an example, responsibilities were sometimes divided between a staff member who focused on employment and another who focused on personal or family issues. While it required 
greater coordination, participants using this team approach were enthusiastic about it, because it brought staff members with different areas of expertise into the case. This enabled each team member to focus on a limited range of issues, but without neglecting other needs. Box IV-A provides examples of programs that used each of these approaches.

\section{Box IV-A}

\section{NCP Case Management Approaches}

Single Case Manager. The Institute for Responsible Fatherhood and Family Revitalization (IRFFR) in Milwaukee places strong emphasis on intensive case management and staff role modeling. Staff are required to model a "risk-free lifestyle" (no drugs or alcohol) as a condition of employment. IRFFR seeks to hire married couples to serve as Managing Partners (program administrators) and Outreach Specialists. Each participant is assigned to an Outreach Specialist, who lives in the neighborhood and is available to participants by telephone or in person 24 hours a day. Outreach Specialists provide counseling through frequent home visits and also connect participants to services and employment opportunities.

Team Case Management. In the DeKalb Fatherhood Connection program, noncustodial parents work closely with two different staff members. A Job Coach is responsible for all employment-related issues, such as job readiness, job search and placement, and job retention. A Family Advocate is responsible for managing all other aspects of the case including intake and assessment, parenting and family issues, and participation in education and training activities. One Job Coach and one Family Advocate form a "team" (there are five teams in all) and communicate frequently about their shared cases. Each team is located in a different neighborhood and works with all program participants in that community.

\section{Program Staff Reported that NCPs Required Intensive Case Management Services.}

Program staff usually characterized the case management services provided to NCPs as "intensive" or "comprehensive," and staff devoted substantial time. Program administrators tried to minimize caseloads for staff and often split case management responsibilities among multiple staff or agencies, both before and after employment. In some programs, case managers were accessible to participants 24 hours a day through phones or pagers. 


\section{EMPLOYMENT AND POSTEMPLOYMENT SERVICES}

At the heart of the assistance each program offered were the services that enhanced the employability of NCPs. All programs helped noncustodial parents find jobs, and for the most part this was the focus of their programs. Exhibit IV-1 shows an overview of key features of the employment services that individual sites provided.

\section{Programs Focused on Moving People into Jobs Quickly through Individualized Job}

Search and Job Readiness Services. Job search, in which NCPs looked for employment directly, and job readiness activities, which provided training in job preparation and soft skills, were the principal services in all the programs we studied. These services were provided primarily through individualized, one-on-one meetings with program staff and focused on finding immediate employment. The services included developing job readiness skills (interviewing techniques, resume development, communication skills), job counseling, planning and overseeing the job search process, providing of job leads, and helping with the job applications.

Because NCPs faced multiple barriers to employment, staff consistently reported working intensively with them during the job search period and meeting or speaking with them frequently until they found a job. Services were individualized, and only one program established work search requirements for the NCP. In the Los Angeles NCP-to-Work program, 30 hours per week of independent job search was required.

In about half of the study sites, community-based organizations that had experience serving disadvantaged individuals (though not necessarily NCPs) provided job readiness, job search, and job placement activities. Many of the sites used multiple providers. In the other half of the sites, the lead agency provided these services directly. Some programs used contracts with different service providers to provide job search services to NCPs with special needs. For example, 
Exhibit IV-1: Employment and Postemployment Services in NCP Programs

\begin{tabular}{|c|c|c|c|c|c|c|}
\hline Program Site & $\begin{array}{c}\text { Dekalb Fatherhood } \\
\text { Connection } \\
\text { Decatur, GA } \\
\end{array}$ & $\begin{array}{c}\text { Full Employment } \\
\text { Council CCP } \\
\text { Kansas City, MO } \\
\end{array}$ & $\begin{array}{l}\text { Houston Works } \\
\text { Houston, TX }\end{array}$ & $\begin{array}{l}\text { IRFFR Program } \\
\text { Milwaukee, WI }\end{array}$ & $\begin{array}{c}\text { LA County NCP-to- } \\
\text { Work Program } \\
\text { Los Angeles, CA } \\
\end{array}$ & $\begin{array}{l}\text { LA Veterans in } \\
\text { Progress } \\
\text { Los Angeles, CA }\end{array}$ \\
\hline $\begin{array}{l}\text { Employment } \\
\text { Services }\end{array}$ & \begin{tabular}{|l|} 
- Self-directed job \\
search with \\
assistance from \\
program staff \\
- Job readiness classes \\
provided by Dekalb \\
Economic \\
Opportunity \\
Authority and Dept. \\
of Labor \\
employment \\
resources used on as- \\
needed basis \\
- Program staff \\
develop linkages \\
with employers
\end{tabular} & $\begin{array}{l}\text { - Self-directed job } \\
\text { search with } \\
\text { assistance from FEC } \\
\text { staff, including some } \\
\text { staff working with } \\
\text { employers to identify } \\
\text { openings }\end{array}$ & $\begin{array}{l}\text { - Specific services } \\
\text { vary by } \\
\text { subcontractor, but } \\
\text { contractors typically } \\
\text { provide one-on-one } \\
\text { job search assistance } \\
\text { and access to } \\
\text { readiness workshops } \\
\text { - Basic skills/GED } \\
\text { instruction and short- } \\
\text { term training } \\
\text { available }\end{array}$ & \begin{tabular}{|l|} 
- Individualized \\
employment \\
services, including \\
job search and job \\
readiness \\
- Weekly peer group \\
sessions that cover \\
some employment- \\
related topics \\
- Staff maintain close \\
linkages with several \\
large local employers \\
- On-site instruction \\
on basic computer \\
software; referrals to \\
education/training
\end{tabular} & $\begin{array}{l}\text { - Peer Support Group } \\
\text { that addresses self- } \\
\text { esteem, employment, } \\
\text { and parenting issues } \\
\text { is initial activity } \\
\text { - } 24 \text { hours of } \\
\text { structured job } \\
\text { readiness activities } \\
\text { - For those } \\
\text { unemployed after } \\
\text { these activities, } 30 \\
\text { hours of independent } \\
\text { job search is required }\end{array}$ & $\begin{array}{l}\text { - Job search and job } \\
\text { readiness activities, } \\
\text { including access to } \\
\text { job developers } \\
\text { - Classroom training, } \\
\text { basic skills training, } \\
\text { and work experience } \\
\text { available } \\
\text { - Training programs } \\
\text { include culinary arts, } \\
\text { construction, and } \\
\text { customized training } \\
\text { programs with } \\
\text { Toyota and Marriott }\end{array}$ \\
\hline $\begin{array}{l}\text { Post-employment } \\
\text { Services }\end{array}$ & $\begin{array}{l}\text { - Job retention follow- } \\
\text { up on a monthly } \\
\text { basis (at minimum) } \\
\text { - Emphasis on } \\
\text { enrolling } \\
\text { noncustodial parents } \\
\text { (NCPs) in education } \\
\text { and training once } \\
\text { working } \\
\end{array}$ & $\begin{array}{l}\text { - Job retention follow- } \\
\text { up on a monthly } \\
\text { basis (at minimum) } \\
\text { - After three months } \\
\text { on the job, } \$ 300 \\
\text { voucher for work- } \\
\text { related expenses; } \\
\text { after } 18 \text { months, a } \\
\$ 1,500 \text { voucher } \\
\end{array}$ & $\begin{array}{l}\text { - Job retention } \\
\text { addressed through } \\
\text { continuing case } \\
\text { management }\end{array}$ & $\begin{array}{l}\text { - Job retention } \\
\text { addressed through } \\
\text { continuing case } \\
\text { management }\end{array}$ & $\begin{array}{l}\text { - Job retention } \\
\text { addressed through } \\
\text { continuing case } \\
\text { management }\end{array}$ & $\begin{array}{l}\text { - Job retention } \\
\text { services, with focus } \\
\text { on obtaining } \\
\text { additional training }\end{array}$ \\
\hline \begin{tabular}{|l} 
Employment \\
Support
\end{tabular} & $\begin{array}{l}\text { - Transportation } \\
\text { assistance in the } \\
\text { form of bus tokens or } \\
\text { transit passes } \\
\text { - Assistance with } \\
\text { work-related } \\
\text { expenses }\end{array}$ & $\begin{array}{l}\text { - Assistance with } \\
\text { transportation } \\
\text { including bus passes, } \\
\text { car repairs, car } \\
\text { insurance, special } \\
\text { licenses, and van and } \\
\text { taxi service } \\
\text { - Assistance with } \\
\text { work-related expenses }\end{array}$ & $\begin{array}{l}\text { - Transportation } \\
\text { assistance includes } \\
\text { bus passes/tokens, } \\
\text { gas allowance, and } \\
\text { help with car repairs } \\
\text { - Assistance with } \\
\text { work-related } \\
\text { expenses }\end{array}$ & $\begin{array}{l}\text { - Assistance with } \\
\text { transportation and } \\
\text { work expenses }\end{array}$ & $\begin{array}{l}\text { Vouchers for work- } \\
\text { related expenses, } \\
\text { transportation, and } \\
\text { housing which may } \\
\text { be used for up to six } \\
\text { months after } \\
\text { employment }\end{array}$ & $\begin{array}{l}\text { - On-site housing is } \\
\text { provided; transitional } \\
\text { housing provided to } \\
\text { those who leave } \\
\text { program } \\
\text { - Assistance with } \\
\text { transportation and } \\
\text { work expenses }\end{array}$ \\
\hline
\end{tabular}


Exhibit IV-1 (continued)

\begin{tabular}{|c|c|c|c|c|c|}
\hline Program Site & $\begin{array}{c}\text { Milwaukee PIC Program } \\
\text { Milwaukee, WI }\end{array}$ & $\begin{array}{c}\text { Minneapolis FATHER } \\
\text { Project } \\
\text { Minneapolis, MN }\end{array}$ & $\begin{array}{l}\text { Nevada Business } \\
\text { Services } \\
\text { Las Vegas, NV }\end{array}$ & $\begin{array}{c}\text { WI Dept. of Corrections } \\
\text { NOW } \\
\text { Milwaukee, WI }\end{array}$ & $\begin{array}{c}\text { Yakima SHARE } \\
\text { Program } \\
\text { Yakima, WA }\end{array}$ \\
\hline $\begin{array}{l}\text { Employment } \\
\text { Services }\end{array}$ & $\begin{array}{l}\text { - Services provided } \\
\text { through subcontracting } \\
\text { agencies. Each has } \\
\text { flexibility to design its } \\
\text { own services but strong } \\
\text { emphasis on job search } \\
\text { and job readiness } \\
\text { activities, and job } \\
\text { retention }\end{array}$ & $\begin{array}{l}\text { - Employment services } \\
\text { vary by provider, but } \\
\text { strong emphasis on job } \\
\text { search and job readiness } \\
\text { - Education, training, and } \\
\text { on-the-job training } \\
\text { options are available }\end{array}$ & $\begin{array}{l}\text { - Nevada Partners: Job- } \\
\text { ready NCPs enroll in } \\
\text { four-hour job readiness } \\
\text { workshop; NCPs not yet } \\
\text { job ready enroll in two- } \\
\text { week job readiness } \\
\text { workshops } \\
\text { - Services Project 2000: } \\
\text { eight-week workshop } \\
\text { for offenders nearing } \\
\text { release } \\
\text { - Both projects emphasize } \\
\text { individualized job } \\
\text { search after workshops } \\
\text { are completed }\end{array}$ & $\begin{array}{l}\text { - Specific approaches and } \\
\text { services vary by W-2 } \\
\text { agency, but generally } \\
\text { include job readiness } \\
\text { workshops and job } \\
\text { search assistance, with a } \\
\text { small number of } \\
\text { referrals for short-term } \\
\text { job training }\end{array}$ & $\begin{array}{l}\text { - Individualized job } \\
\text { search and job } \\
\text { readiness provided } \\
\text { - NCPs sometimes } \\
\text { referred to same job } \\
\text { search classes as other } \\
\text { Welfare-to-Work and } \\
\text { Workforce Investment } \\
\text { Act participants } \\
\text { - Some OJT and work } \\
\text { experience slots are used }\end{array}$ \\
\hline $\begin{array}{l}\text { Post Employment } \\
\text { Services }\end{array}$ & $\begin{array}{l}\text { - Job retention addressed } \\
\text { through continuing case } \\
\text { management } \\
\text { - Subcontractors make } \\
\text { skill upgrading } \\
\text { available after a } \\
\text { participant secures a job }\end{array}$ & $\begin{array}{l}\text { - Job retention addressed } \\
\text { through continuing case } \\
\text { management }\end{array}$ & $\begin{array}{l}\text { - Job retention addressed } \\
\text { through continuing case } \\
\text { management }\end{array}$ & $\begin{array}{l}\text { - Varies by provider but } \\
\text { job retention generally } \\
\text { addressed through } \\
\text { continuing case } \\
\text { management }\end{array}$ & $\begin{array}{l}\text { - Job retention addressed } \\
\text { through continuing case } \\
\text { management }\end{array}$ \\
\hline $\begin{array}{l}\text { Employment } \\
\text { Support }\end{array}$ & $\begin{array}{l}\text { - Subcontracting agencies } \\
\text { offer a range of support } \\
\text { services directly or } \\
\text { through referrals, } \\
\text { including transportation } \\
\text { assistance and work- } \\
\text { related assistance }\end{array}$ & $\begin{array}{l}\text { - Assistance with } \\
\text { transportation, short- } \\
\text { term emergencies (rent, } \\
\text { utilities), and work- } \\
\text { related expenses }\end{array}$ & $\begin{array}{l}\text { - Transportation } \\
\text { assistance includes bus } \\
\text { passes/tokens, gas } \\
\text { allowance, help with car } \\
\text { repairs } \\
\text { - Assistance with work- } \\
\text { related expenses }\end{array}$ & $\begin{array}{l}\text { - Contracting agencies } \\
\text { offer wide range of } \\
\text { support services directly } \\
\text { or through referrals, } \\
\text { including transportation } \\
\text { assistance and work- } \\
\text { related expenses }\end{array}$ & $\begin{array}{l}\text { - Transportation } \\
\text { assistance and work- } \\
\text { related expenses } \\
\text { provided }\end{array}$ \\
\hline
\end{tabular}


Houston Works contracted with providers who specialized in serving homeless families, disabled people, and refugees. Yakima SHARE could make referrals to providers who specialized in providing employment services to youth or people with substance abuse problems.

Participation in group job readiness workshops prior to entering a direct job search was emphasized in some sites, including the programs in Nevada and Los Angeles County:

- In the Nevada Business Services program, for those who were job ready, the contractor provided a four-hour job readiness class. Those who were not job ready were enrolled in a two-week job readiness program that included sessions on goal setting, building self-esteem, managing conflict, and effective job search strategies. Another contractor for this program also provided structured job readiness services for soon-to-be-released female NCP offenders (see Box IV-B).

- The Los Angeles County NCP-to-Work program developed a Job Club exclusively for NCPs, which lasted 24 hours (spread over several days) and focused on developing job skills, preparing resumes, building communication skills, and learning interview techniques.

In other programs, group job readiness services were used less systematically, although NCPs were sometimes referred to existing workshops operated by community-based organizations or one-stop career centers on an as-needed basis. 


\section{Box IV-B}

\section{Employment Services for Female NCP Offenders}

Nevada Business Services contracts with Services Project 2000 to provide a unique set of employment-related services for soon-to-be-released female noncustodial parents. Participants attend an eight-week, 32-session workshop that follows a formal curriculum focused on life skills, self-esteem, anger management, effective communication, and motivation. There are also sessions on family success, relationships, and parenting, as well as securing and keeping a job. At the conclusion, participants are given a "diploma of life" at a special ceremony. The workshop is followed by weekly peer group sessions until the woman is released from prison. As release time approaches for each participant, program staff identify job leads and a range of other support services to ease the transition from prison into the community. Once a woman is employed, assistance is available 24 hours a day, seven days a week to troubleshoot problems and arrange for services.

\section{Developing and Maintaining Relationships with Employers Was Viewed as Critical.}

Most programs had staff that worked to develop linkages with employers, usually as part of the individualized job search services that were provided. Staff focused on developing an in-depth understanding of the local labor market and contacting employers to identify specific job openings appropriate for their clientele. Some staff found that they increased employer interest by "selling" the program, that is, by directly explaining the mission of the program, which reportedly helped overcome negative views of some employers. Staff also emphasized to employers the availability of screening services, tax credits, and no-cost retention services (see below) to attract employers.

Education and Training Programs Were Not Used Extensively. Program staff reported that even when education and training services were made available, NCPs were reluctant to use them. This lack of interest in education and training to upgrade skills was usually the result of the NCPs' interest in seeking paid employment as quickly as possible. In many cases, NCPs had a pressing need to pay child support and support their families. 
While NCPs did not use education and training services at high rates, several of the programs did make these services available. Some made referrals to existing programs in the community, while others had directly funded or had developed education and training programs for their participants. Some examples include:

- IRFFR assigned a staff member to provide basic training on the most frequently used computer software applications. Volunteers also provided on-site literacy instruction.

- Houston Works had subcontractors who offered short-term training for the following occupations: computer operator, truck driver, certified mechanic, certified nursing assistant, corrections officer, bank teller, customer service representative, and retail clerk, among others.

- The LA Vets program developed agreements with Toyota and Marriott to provide customized training (with the person receiving a wage during the training period), with a guarantee of employment upon completion of the program.

There was also little use of subsidized employment services such as on-the-job training and work experience. Because the economy was strong and because NCPs preferred unsubsidized employment, program operators preferred to place people directly into unsubsidized jobs. One exception was the Yakima SHARE program, which provided on-the-job training and work experience to NCPs as well as other WtW participants. In part, this was due to the community's history of providing subsidized-employment opportunities in a range of different programs.

Postemployment Services Were a Key Program Element. All the programs included in this study continued to provide assistance to NCPs after they started working. As shown on Exhibit IV-1, most of the programs focused on providing follow-up to improve job retention, although one program provided financial incentives as well (see Box IV-C). This follow-up assistance usually consisted of: (1) contacting NCPs on a monthly or biweekly basis to ensure that they were still working, and (2) troubleshooting to guard against job loss. Several of the programs also contacted employers directly for their perspective on the person's job 
performance. Staff also reported that employers considered the availability of follow-up services an important element in their decision to hire an NCP. Programs generally worked with NCPs for an indefinite period of time after they found a job—and did not have a specific point when services would end.

Support services were also an important postemployment service. Most programs continued to help with transportation and work-related expenses once the participant found a job. For example, the Kansas City CPP spent a large portion of its WtW grant on providing transportation resources to people who had returned to work. Monthly bus passes were available to help employed individuals get to and from work, and one-time payments were made to help with automobile repair, insurance, and fees for special driver's licenses if they were required for a job (e.g., a commercial driver's license). The Full Employment Council (FEC) also received a grant that provides "door to job" transportation for the CPP program—-to help participants who live in rural areas with no bus service or who need off-hours transportation for second- and third-shift jobs. These funds can pay for taxi rides, vans, or other transportation alternatives to assist the participant in maintaining employment.

Issues related to career advancement, such as combining work and school or moving to a better job, generally did not receive high priority. While several of the programs recognized this as important, it was handled primarily on a case-by-case basis, with staff helping participants pursue these options when they could. One exception was the Dekalb Fatherhood Connection, which made a systematic effort (and reported some success) in enrolling program participants in some type of education or training once they were working. 


\section{Box IV-C}

\section{Financial Incentives to Promote Job Retention}

To motivate noncustodial parents and other Welfare-to-Work (WtW) participants to find and retain employment and pay child support, the Kansas City Concerned Parent Program uses WtW funds to create financial incentives: vouchers that allow participants to purchase a variety of employment-related goods and services. A participant who holds a job for three months receives a $\$ 300$ voucher and, after nine months, a $\$ 1,500$ voucher.

\section{PARENTING AND RELATIONSHIP SERVICES}

Most programs visited as part of this study focused on enhancing employment outcomes and improving timely payment of child support, but some addressed parenting and relationship issues as well, including developing parenting skills, improving access and visitation to the noncustodial parent's children, building relationships with the child's other parent (including mediation services), and assisting with child support issues. Exhibit IV-2 provides an overview of key features of these parenting and relationship services in the individual sites.

Parenting and Relationship Services Were Not a Priority in All Programs, but Most Programs Provided Access to Some Type of Assistance. The scope and intensity of services provided to improve parenting skills and help NCPs cope with relationship issues varied across the sites. Both the IRFFR and the Minneapolis FATHER Project placed a strong emphasis on parenting, improving access and visitation, and improving relationships with the child's other parent. These parenting services were fully integrated and strongly emphasized, primarily through regularly scheduled peer support sessions and individual counseling sessions. The Minneapolis program also provided on-site legal services on custody issues (see Box IV-D). In addition, while the Wisconsin DOC's Project NOW itself did not have a strong parenting 
Exhibit IV-2: Parenting and Other Services in NCP Programs

\begin{tabular}{|c|c|c|c|c|c|c|}
\hline Program Site & $\begin{array}{c}\text { Dekalb Fatherhood } \\
\text { Connection } \\
\text { Decatur, GA }\end{array}$ & $\begin{array}{l}\text { Full Employment } \\
\text { Council CCP } \\
\text { Kansas City, MO }\end{array}$ & $\begin{array}{c}\text { Houston Works } \\
\text { Houston, TX }\end{array}$ & $\begin{array}{l}\text { IRFFR Program } \\
\text { Milwaukee, WI }\end{array}$ & $\begin{array}{l}\text { LA County NCP-to- } \\
\text { Work Program } \\
\text { Los Angeles, CA }\end{array}$ & $\begin{array}{c}\text { LA Veterans in } \\
\text { Progress } \\
\text { Los Angeles, CA }\end{array}$ \\
\hline $\begin{array}{l}\text { Parenting and } \\
\text { Relationship } \\
\text { Services and } \\
\text { Assistance on } \\
\text { Child Support Issues }\end{array}$ & $\begin{array}{l}\text { - Referrals made to } \\
\text { other organizations } \\
\text { for parenting services } \\
\text { and peer support } \\
\text { groups and to a new } \\
\text { statewide program } \\
\text { focused on access/ } \\
\text { visitation issues } \\
\text { - Staff provide informal } \\
\text { support and guidance } \\
\text { on parenting issues } \\
\text { - Liaison from CSE } \\
\text { provides assistance } \\
\text { with child support and } \\
\text { employment services }\end{array}$ & 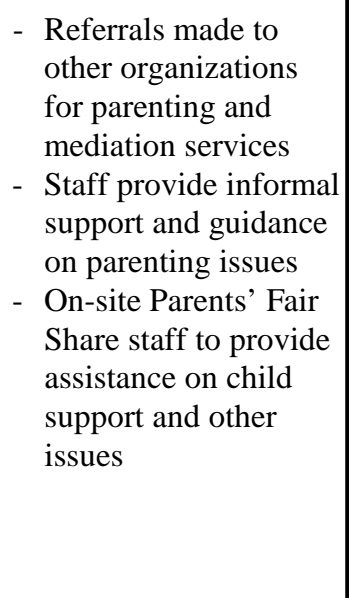 & $\begin{array}{l}\text { - Referrals made to } \\
\text { other organizations } \\
\text { for parenting, peer } \\
\text { support groups, and } \\
\text { mediation services } \\
\text { - Planning to contract } \\
\text { with two agencies to } \\
\text { provide parenting } \\
\text { workshops }\end{array}$ & $\begin{array}{l}\text { - Emphasis of project is } \\
\text { on reconnecting } \\
\text { noncustodial parents } \\
\text { (NCPs) with their } \\
\text { children and } \\
\text { improving parenting } \\
\text { skills } \\
\text { - One-on-one } \\
\text { counseling and } \\
\text { weekly peer support } \\
\text { groups are primary } \\
\text { interventions }\end{array}$ & $\begin{array}{l}\text { - Parenting services } \\
\text { provided informally } \\
\text { through peer support } \\
\text { group meetings } \\
\text { - } \text { Mediation provided } \\
\text { upon request of NCP } \\
\text { (primarily to deal with } \\
\text { child support, not } \\
\text { custody issues) } \\
\text { - Designated CSE staff } \\
\text { to provide assistance } \\
\text { on child support } \\
\text { issues }\end{array}$ & $\begin{array}{l}\text { - Parenting is covered } \\
\text { informally as part of } \\
\text { evening workshops } \\
\text { and peer support } \\
\text { sessions } \\
\text { - Representative from } \\
\text { District Attorney } \\
\text { available to assist on } \\
\text { child support issues }\end{array}$ \\
\hline Other Services & $\begin{array}{l}\text { - Referrals to other } \\
\text { organizations (after } \\
\text { employment) for } \\
\text { substance abuse, } \\
\text { anger management, } \\
\text { and mental health } \\
\text { issues }\end{array}$ & $\begin{array}{l}\text { - Referrals to other } \\
\text { organizations (after } \\
\text { employment) for } \\
\text { substance abuse and } \\
\text { mental health issues }\end{array}$ & $\begin{array}{l}\text { - Range of support } \\
\text { services offered } \\
\text { directly or through } \\
\text { referrals, including } \\
\text { housing, child care, } \\
\text { substance abuse } \\
\text { treatment, and mental } \\
\text { health treatment }\end{array}$ & $\begin{array}{l}\text { - Referrals to other } \\
\text { organizations for } \\
\text { assistance with } \\
\text { transportation, } \\
\text { housing, substance } \\
\text { abuse and other } \\
\text { services }\end{array}$ & $\begin{array}{l}\text { - Domestic violence } \\
\text { program that refers } \\
\text { both abusers and } \\
\text { abused to outside } \\
\text { agencies for } \\
\text { counseling } \\
\text { - Referrals to other } \\
\text { organizations for } \\
\text { substance abuse } \\
\text { treatment (including } \\
\text { those identified by } \\
\text { employers) } \\
\text { - Vouchers for work- } \\
\text { related expenses, } \\
\text { transportation, and } \\
\text { housing which may be } \\
\text { used for up to six } \\
\text { months after } \\
\text { employment }\end{array}$ & $\begin{array}{l}\text { - On-site housing is } \\
\text { provided; transitional } \\
\text { housing provided to } \\
\text { those who leave } \\
\text { program } \\
\text { - Seven on-site staff to } \\
\text { provide counseling } \\
\text { and other services on } \\
\text { a range of issues }\end{array}$ \\
\hline
\end{tabular}


Exhibit IV-2 (continued)

\begin{tabular}{|c|c|c|c|c|c|}
\hline Program Site & $\begin{array}{c}\text { Milwaukee PIC Program } \\
\text { Milwaukee, WI }\end{array}$ & $\begin{array}{c}\text { Minneapolis FATHER } \\
\text { Project } \\
\text { Minneapolis, MN }\end{array}$ & $\begin{array}{l}\text { Nevada Business } \\
\text { Services } \\
\text { Las Vegas, NV }\end{array}$ & $\begin{array}{c}\text { WI Dept. of Corrections } \\
\text { NOW } \\
\text { Milwaukee, WI }\end{array}$ & $\begin{array}{c}\text { Yakima SHARE } \\
\text { Program } \\
\text { Yakima, WA }\end{array}$ \\
\hline $\begin{array}{l}\text { Parenting and } \\
\text { Relationship Services } \\
\text { and Assistance on } \\
\text { Child Support Issues }\end{array}$ & $\begin{array}{l}\text { - Staff provide informal } \\
\text { support and guidance on } \\
\text { parenting issues } \\
\text { - Subcontractors } \\
\text { encouraged to develop } \\
\text { parenting component } \\
\text { - Subcontract with Legal } \\
\text { Action of Wisconsin } \\
\text { makes a wide array of } \\
\text { legal services available }\end{array}$ & $\begin{array}{l}\text { - Biweekly peer support } \\
\text { groups that address } \\
\text { parenting issues } \\
\text { - Staff provide informal } \\
\text { support and guidance on } \\
\text { parenting issues } \\
\text { - Monthly family events } \\
\text { - On-site legal assistance } \\
\text { for custody issues } \\
\text { - Referrals for mediation } \\
\text { services } \\
\text { - Designated CSE case } \\
\text { workers to assist on } \\
\text { child support issues }\end{array}$ & $\begin{array}{l}\text { - Services Project } 2000 \\
\text { includes workshop } \\
\text { modules focused on } \\
\text { family and parenting } \\
\text { issues } \\
\text { - Both contractors can } \\
\text { refer participants for } \\
\text { legal or mediation } \\
\text { services }\end{array}$ & $\begin{array}{l}\text { - Varies by provider. } \\
\text { Employment Solutions } \\
\text { offers formal 26-session } \\
\text { responsible-parenting } \\
\text { curriculum; United } \\
\text { Migrant Opportunity } \\
\text { Services offers 10- } \\
\text { session “Survival Skills } \\
\text { for Men,” which } \\
\text { includes parenting } \\
\text { curriculum; other W-2 } \\
\text { agencies designing } \\
\text { fatherhood/ parenting } \\
\text { curriculum }\end{array}$ & $\begin{array}{l}\text { - Staff provide informal } \\
\text { support and guidance on } \\
\text { parenting and child } \\
\text { support issues } \\
\text { - Recently started } \\
\text { developing peer support } \\
\text { sessions } \\
\text { - Regular meetings with } \\
\text { staff from the District } \\
\text { Attorney's office on } \\
\text { child support and other } \\
\text { issues }\end{array}$ \\
\hline Other Services & $\begin{array}{l}\text { - Subcontracting agencies } \\
\text { offer a range of support } \\
\text { services directly or } \\
\text { through referrals, } \\
\text { including legal } \\
\text { assistance, substance } \\
\text { abuse treatment, and } \\
\text { housing assistance } \\
\text { - Subcontracting agencies } \\
\text { offer specialized } \\
\text { services (e.g., one } \\
\text { agency specializes in } \\
\text { providing services for } \\
\text { NCPs with mental } \\
\text { health and substance } \\
\text { abuse problems) }\end{array}$ & $\begin{array}{l}\text { - Referrals for substance } \\
\text { abuse, mental health, } \\
\text { and anger management } \\
\text { issues }\end{array}$ & $\begin{array}{l}\text { - Referrals for housing, } \\
\text { child care, substance } \\
\text { abuse, and mental health } \\
\text { treatment. }\end{array}$ & $\begin{array}{l}\text { - Subcontracting agencies } \\
\text { offer wide range of } \\
\text { support services directly } \\
\text { or through referrals, } \\
\text { including housing } \\
\text { assistance, substance } \\
\text { abuse treatment and } \\
\text { mental health issues }\end{array}$ & $\begin{array}{l}\text { - Range of services } \\
\text { provided through } \\
\text { referrals, including } \\
\text { mental health, domestic } \\
\text { violence, and anger } \\
\text { management services } \\
\text { - Individuals with } \\
\text { substance abuse } \\
\text { problems referred to } \\
\text { provider who specializes } \\
\text { in serving this } \\
\text { population }\end{array}$ \\
\hline
\end{tabular}


focus, one of the five contractors providing services under this model offered a comprehensive 26-week parenting curriculum (see Box IV-D).

In other sites we visited, parenting issues were not as central to the programs. A few programs and agencies, such as LA Vets and Services Project 2000 (a subcontractor to Nevada Business Partners in Las Vegas [see Box IV-B above]), incorporated parenting issues and instruction into other workshops that dealt more broadly with basic skills and work readiness. In all programs, case managers addressed issues relating to parenting, custody, or relationships with the child's parent as they arose and provided individual counseling as needed. In addition, all sites made referrals to parenting workshops and mediation services sponsored by other agencies. However, program staff reported that they rarely made such referrals.

A few programs had not focused on parenting issues initially, but had subsequently began to develop options in this area. The Houston Works project was planning to add two new subcontractors that would concentrate on providing parental skills workshops and counseling for NCPs in need of intensive help. While an important part of the original program design, the Yakima SHARE program initially focused on implementing the other components of the program (e.g., employment-related services) and just recently started to offer peer support sessions featuring an increased emphasis on parenting issues. 


\section{Box IV-D}

\section{Examples of Parenting and Relationship Services}

- Wisconsin Department of Corrections NOW Program. Two of the five agencies providing direct services under this initiative have implemented parenting/fatherhood program components; the other W-2 agencies are in various stages of planning or implementation. Employment Solutions (affiliated with Goodwill Industries of Southeastern Wisconsin) offers a comprehensive, 26-session parenting/fatherhood workshop for NOW participants. Sessions cover values, manhood, understanding the child support system, understanding children's needs, coping as a single father, male/female relationships, men's health, and substance abuse issues. A second agency, United Migrant Opportunity Services, also offers a ten-session workshop, entitled "Survival Skills for Men." The small-group workshop sessions (three hours each, held twice a week) cover budgeting, parenting, health, grooming/dressing, and a range of other topics.

- Minneapolis FATHER Project. The Minneapolis FATHER Project conducts biweekly peer support groups using a formal curriculum and also sponsors monthly family events for noncustodial parents (NCPs). This program also has a part-time staff person responsible for assisting NCPs with resolving visitation and custody issues. This staff person operates a law clinic, where 14 volunteer attorneys are available to provide advice on custody matters. In addition, this project made mediation services available through referral to the county's family services agency.

- Institute for Fatherhood and Family Revitalization. The emphasis of the Milwaukee IRFFR project is on reconnecting NCPs with their children and improving parenting skills. The main intervention is direct, one-on-one counseling with each participant. At the core of the project is a belief that attitude change leads to other positive consequences, such as greater involvement with children, payment of child support, paternity establishment, and long-term employment. NCPs also attend weekly peer support groups, in which they can discuss parenting, relationships, work, and a range of other topics. Once the NCP is engaged, the program seeks to bring in the custodial parent for individual counseling and peer support groups. An important goal of the program is to resolve relationship disputes between the noncustodial and custodial parents, so that the NCP can become actively involved financially and emotionally with the children. IRFFR refers participants to other agencies for paternity establishment, as well as mediation and legal assistance related to child support and visitation. 
While there is a requirement in the $\mathrm{WtW}$ amendments for consultations with domestic violence providers, at the time of our site visits, these had not yet occurred in most programs. One site-LA County_operated a program funded by TANF for both abusers and victims of domestic violence. Program staff were trained on the issues, including the indicators of domestic violence, and referred participants to suitable agencies for counseling and treatment. The Yakima SHARE program made referrals to community-based organizations (usually the YWCA) for domestic violence services.

Some Programs Assisted Individuals on Child Support Issues. Program staff consistently reported that low-income NCPs did not have a good understanding of the child support enforcement system and were wary of connecting with the system. To address this issue, several programs systematically worked with the NCPs to both help them better understand the child support system and ensure that he made child support payments once he found a job-but reportedly in a less adversarial way than traditional child support enforcement agency staff. Various staff performed this function, and in some sites designated staff from the child support enforcement agency took on this role. Programs placing some emphasis on this issue included those with a strong partnership with the child support agency (e.g., Houston and Yakima) as well as others:

- Staff in the Dekalb program strongly emphasized the requirements of the child support system in its program orientation. In addition, a liaison from the child support agency assisted the program's case managers in resolving any issues that may have prevented the NCP from finding or keeping a job and in ensuring that child support payments were made.

- In Minneapolis, a supervisor and two line staff at the child support enforcement agency worked with all NCPs in the FATHER Project. Once a NCP was enrolled in the program, these staff worked with the participant (if necessary) to establish paternity and establish an order. They also worked with participants-both before and once they begin working - on arranging the different adjustments to child support payments that this program offers (e.g., delaying and modifying orders, stopping interest on arrearages). 
- In the LA Vets program, participants met with a representative from the District Attorney's office as soon as they found a job to discuss payment issues for child support orders and arrearages.

While some programs directly addressed helping NCPs understand the child support system, other programs did not. Those where there was no systematic method for addressing child support issues typically had case managers address child support issues on an as-needed basis.

\section{E. OTHER TYPES OF SERVICES}

Employment services were the focus of this set of programs for noncustodial parents, but because participants face significant barriers to employment, program operators recognized that it was important to offer a wider array of supportive services.

\section{Specialized Services Were Made Available Primarily through Referrals to Other}

Organizations. As shown on Exhibit IV-2, most of the programs in this study made specialized services available to participants through referrals to other organizations with expertise in the appropriate area. For example, individuals with substance abuse or mental health problems were referred to providers who offered appropriate treatment or counseling programs. Most programs—including such programs as Dekalb Fatherhood Connection, Houston Works, and Nevada Business Partners-were also prepared to make referrals to other local providers for housing assistance, anger management, or peer support groups on an as-needed basis. A few programs also made referrals for child care assistance, which NCPs needed on occasion.

As discussed in a previous section, a few of the programs (e.g., Houston Works and Yakima SHARE) subcontracted with providers that specialized in employment and other services to people with particular barriers, such as substance abuse problems. Usually, however, these programs did not have contractual arrangements with other agencies for such services. Rather, programs established the necessary, often informal linkages with appropriate organizations so 
that referrals could be made on a timely basis.

Referral Rates to These Other Types of Services Were Generally Low. While a wider range of services was available, most programs reported that few referrals were actually made to them. Staff reported that it was often difficult for NCPs to admit to or seek help for some of the problems they were experiencing. So that substance abuse problems could be identified and resolved, staff in the LA County program were notified by employers when on-the-job drug tests were positive. NCPs were then required to go through an assessment that could lead to re-entry into the program or referral to a treatment program.

Of the programs in our study, the LA Vets program offered the widest range of services (beyond those for employment). It was a residential program in which participants lived on site in dormitory-style suites. If participants found a job, they paid the lesser of $\$ 50$ or one-third of their earnings per week for housing. In addition, participants who left the program were eligible for transitional housing at the same site. Counseling was also provided on site, and participants' medical expenses were covered through their veterans' benefits (although most medical services were provided off site). 


\section{CONCLUSIONS}

The 11 programs serving noncustodial parents under the WtW grants program reviewed in the previous sections represent different approaches to serving this low-income population. The experiences of these programs provide a number of insights into how to structure and implement programs for NCPs. Although the sample of sites visited is small and the results not nationally representative, a few observations and conclusions might be useful to others interested in similar programs.

A Vvariety of Public and Private Organizations Can Establish and Operate Programs for Low-Income NCPs. Programs for NCPs are provided through a variety of different structural models and bring together widely varying local partnerships and services. Because each locality operates within a different service environment and economy and serves a different clientele, no single model is necessarily preferable, nor is there a presumptive agency that should be the lead administrative entity. Half the projects examined were administered by workforce development agencies, one was run by a corrections department, and the rest were operated by community-based organizations.

Programs Can Benefit from Collaboration and Coordination among Agencies. Regardless of the administering agency, most projects in this review were collaborative efforts that involved a number of partners, including the workforce development agency, the child support enforcement agency, courts, and community-based organizations. The benefits of interagency collaboration are understandable, since the target population tends to have many problems-personal, legal, and employment-related. No single agency is likely to have the expertise and experience to address the full range of issues and problems adequately. Based on conversations with staff, there seem to be strong reasons to believe that programs for NCPs can 
benefit from collaboration and interagency coordination.

The availability of $\mathrm{WtW}$ funds in the study sites helped promote collaboration to some extent. The presence of the funds provided an impetus for bringing local agencies together around a common purpose-improving employment outcomes so that NCPs can better fulfill their responsibilities to pay child support and take a more active role in the lives of their children. Although it may often be time-consuming and complicated to bring together a number of partners, it is important from several standpoints:

- Partnerships facilitate recruitment, which can be a serious stumbling block to getting programs up and running

- Collaboration can substantially expand the range of services that can be provided for a target group with widely varying needs and few external supports

- Linkages can help to leverage and expand significantly the local resources available to meet the needs of NCPs

\section{Recruitment Is a Critical Challenge and a Major Component of Programs that Serve}

NCPs. For many low-income NCPs, this type of program could be a first step toward improving their employment and earnings potential. However, programs must first gain the trust of the people they are trying to help. The most significant challenges for programs that target NCPs are recruiting and fully engaging NCPs. All programs visited faced some difficulties on this front, at least initially, although most were able to boost their enrollments over time. Several lessons emerge from the implementation experiences of programs reviewed in this report.

- Programs that were most successful in recruiting participants used multiple approaches. Partnering with different agencies to provide a steady source of referrals, particularly from the child support enforcement agency or the courts, is an important strategy that increases program enrollment. However, many of the programs used a variety of other strategies to identify potential program participants. These included the distribution of brochures and flyers, presentations at other agencies, use of PSAs and paid advertisements in the local media, mass mailings, neighborhood recruiting, and word-ofmouth.

- Programs should not underestimate the problems associated with recruiting NCPs. Most of the programs visited assumed that participants would come primarily 
through referrals from other agencies. With few exceptions, the programs realized that referrals alone were not adequate. Adding outreach activities late can be expensive and can divert staff and resources available for direct service delivery. Systematically considering outreach and recruitment strategies before startup could help minimize program disruption later. Once in place, recruitment efforts must be monitored carefully (particularly in the early stages of programs), and changes will be needed to improve outreach and recruitment methods for the eligible and interested NCP population.

- A combination of positive inducements and pressures may prove more successful than either a completely voluntary program or a harshly punitive program. Involving the child support agency and the courts, which can provide both "carrots and sticks" for participation, appears to be important for simultaneously addressing recruitment and program retention issues. Most programs used a mix of both positive (child support payment options, comprehensive program services) and negative incentives (threat of incarceration) to encourage participation. Once NCPs are participating, though, individualized employment and support services by professional staff with small caseloads are essential.

Low-Income NCPs Are Most Interested in Rapid Employment. Program operators reported that, while NCPs faced some of the same challenges to employment as custodial parents (basic skills deficiencies, lack of job-specific skills, and difficulties with job retention), they had some special needs that programs should address. Perhaps most importantly, NCPs typically come to programs under strong pressure (often by courts and child support agencies) to find work quickly because of unpaid and mounting child support payments and other financial pressures. Therefore, this population has a strong and abiding interest in securing a job (or upgrading employment).

Programs that fail to respond quickly to this overriding need will likely experience high levels of attrition. Program staff reported that NCPs generally lack the external supports (e.g., other working family members and access to cash assistance programs) to engage in lengthy job readiness workshops, education and training programs to upgrade skills, or work experience programs. Programs serving this population need to look first to meeting immediate job placement and support services needs, then to considering ways to engage NCPs in programs over a longer period of time (once employed) to upgrade job skills and parenting skills. 


\section{Helping NCPs Understand and Negotiate the Child Support Enforcement System May}

Be an Important Program Service. Based on discussions with program staff, it appears that more low-income NCPs might be interested in improving their employment situation if they understood the child support system better and believed that their efforts would benefit their children. Many low-income NCPs lack accurate information about the child support system, including how payments reach the children and how special payment plans can be arranged. If they understood better how the system works, and if they felt they could trust the programs, they might be more willing to participate seriously and develop long-term child support payment plans. While the programs in this study did not consistently emphasize this issue, some programs have designated specific staff_often from the child support enforcement agency—to assist participants with these issues.

Because of NCPs' interest in employment, program services need to be focused on both preand postemployment activities. However, other types of services may be critical to the NCPs long-term employment prospects. NCPs are interested primarily in obtaining a job quickly, but other employment and support services can help improve their long-run economic status, earnings, and child support payment. Ongoing case management, counseling, and job placement assistance can improve job retention and ensure an effective transition to a new job. Job-training and education activities could complement regular employment to help improve skills. Some NCPs also need a range of other support services to sustain regular employment and fulfill their parenting responsibilities, including mental health or substance abuse treatment, child care or transportation assistance, legal services, housing assistance, and services that address the problems of domestic violence. At a minimum, either through the sponsoring agency or by coordinating with other local service providers, the following are among the core program components: 
- Well-targeted and coordinated outreach and recruitment

- Assessment and employability development planning, culminating in the development of a written individual employment or service plan that identifies participant goals and activities

- Ongoing case management and individual counseling

- Assistance with child support issues

- Job search, job development, and job placement services, including job search workshops, job clubs, help in identifying job leads, and direct job placement assistance

- Job training services, including (1) remedial education and basic skills/literacy instruction, (2) occupational skills training, (3) on-the-job training, and (4) other types of work experience, such as internships/fellowships

- Postplacement follow-up and support services (e.g., additional job placement services, training after placement, support groups, and mentoring)

- A range of other support services that are provided either directly by the project or through referral arrangements with other human services providers, including parenting education; alcohol and other substance abuse assessment and counseling, with referral as appropriate to outpatient and/or inpatient treatment; child care assistance; transportation assistance; referral for mental health assessment, counseling, and treatment; and referral for housing services

The experiences of programs visited underscored the importance of providing a comprehensive range of services to address the varied problems NCPs faced in securing employment and becoming more actively involved in the lives of their children. 


\section{REFERENCES}

A Guide to Funding Services for Children and Families Through the Temporary Assistance for Needy Families (TANF) Program. 1999. Washington, DC: U.S. Department of Health and Human Services.

Doolittle, F., V. Knox, C. Miller, and S. Rowser. 1998. Building Opportunities, Enforcing Obligations: Lessons for Child Support Reform from the Parents' Fair Share Pilot Phase. New York, NY: Manpower Demonstration Research Corporation.

Edin, K., L. Lein, and T. Nelson. 1998. Low Income, Non-Residential Fathers: Off-Balance in a Competitive Economy, An Initial Analysis. Washington, D.C.: U.S. Department of Health and Human Services, available at http://fatherhood.hhs.gov.

Johnson, E., A. Levine, and F. Doolittle. 1999. Fathers' Fair Share. New York, NY: Russell Sage Foundation.

Martinez, J. and C. Miller. 2000. Working and Earning: The Impact of Parents' Fair Share on Low-Income Fathers' Employment, (New York, NY: Manpower Demonstration Research Corporation), 2000.

Martinson, K. 1998. Serving Noncustodial Parents Through Welfare-to-Work Grants: Labor Market Characteristics, Employment Barriers, and Service Strategies. Washington, DC: The Urban Institute.

Mincy, R., and E. Sorensen. 1998. "Deadbeats and Turnips in Child Support Reform." Journal of Policy Analysis and Management, vol. 17, no.1, pp. 44-51.

Office of the Inspector General. 2000. The Establishment of Child Support Orders for LowIncome Noncustodial Parents. Washington, DC: U.S. Department of Health and Human Services.

Pearson, J., N. Thoennes. D. Price, and J. Venohr. 2000. Office of Child Support Enforcement Responsible Fatherhood Programs: Early Implementation Lessons. Denver, CO: Center for Policy Research and Policy Studies, Inc.

Perez-Johnson, I, and A. Hershey. 1999. Early Implementation of the Welfare-to-Work Grants Program: Report to Congress. Princeton, NJ: Mathematica Policy Research, Inc.

Perez-Johnson, I, A. Hershey, and J. Bellotti. 2000. Further Progress, Persistent Constraints: Findings from a Second Survey of the Welfare-to-Work Grants Program. Princeton, NJ: Mathematica Policy Research, Inc.

Reichert, Dana. 1999. Broke But Not Deadbeat: Reconnecting Low-Income Fathers and Children. Washington, DC: National Conference of State Legislatures.

Sorenson, E. 1997. Low-Income Noncustodial Fathers: Who Are They and What Are States Doing to Assist Them in Their Effort to Pay Child Support? Washington, DC: The Urban Institute. 
APPENDIX A

PROFILES OF THE NCP STUDY PROGRAMS 


\section{Dekalb County Fatherhood Connection \\ Decatur, GA}

\section{Overview and Local Context}

The Fatherhood Connection is operated by a community action agency that directly provides employment and case management services to noncustodial parents (NCPs). This program uses a variety of recruitment methods--potential program participants are referred from the child support enforcement agency and recruited directly from the community. Immediate employment is the primary goal of this program. Once the noncustodial parent is working, however, staff also focus on promoting education and training (done concurrently with work) and on addressing a range of other issues, including substance abuse or parenting issues. The Fatherhood Connection operates in Dekalb County - a large urban/suburban county that includes part of Atlanta, Georgia - and serves a primarily African American population.

\section{Lead Agency and Key Partners}

The Dekalb Economic Opportunity Authority-a nonprofit, community-based organization with extensive experience providing Head Start and employment services--provides both the employment and case management services in this program. The Dekalb County Child Support Enforcement Office plays an important role in providing referrals to the program, and the Georgia Department of Labor, the Sheriff's Department, and the Dekalb County Department of Family and Children Services have also been involved in recruitment efforts. Program staff are housed at existing community programs, including local Family Resource Centers and a housing authority.

\section{Funding Source(s) and Enrollment}

The Fatherhood Connection program is funded by a Welfare-to-Work (WtW) competitive grant. The program began operating in April 1999. As of July 2000, there were 160 fathers enrolled in the program.

\section{Target Group}

The program serves NCPs who meet the WtW eligibility criteria.

\section{Incentives for Participation}

Individuals who do not participate in program services or do not start making their child support payments when they find employment can be issued contempt citations and arrested. On the positive side, in addition to program services, the child support enforcement office provides some limited assistance on child support issues for program participants. On a case-by-case basis, the program will reinstate revoked licenses for participants if necessary. For those recruited directly by the Fatherhood Connection program, the child support office will delay the collection of child support or license suspensions for 30 days after program enrollment. 


\section{Outreach and Recruitment Strategies}

The Fatherhood Connection program identifies potential program participants in two ways. First, individuals are recruited directly from the community. To assist in this effort, the program created a communication specialist position to develop and prepare recruitment materials, including a newsletter, flyers, and posters. The location case management teams in specific communities also help in recruitment. These staff are able to develop an in-depth understanding of services, events, and activities in their neighborhood and to identify potential recruitment opportunities. Other outreach strategies include: (1) a widely distributed quarterly newsletter about the program, (2) a mass mailing to all Temporary Assistance for Needy Families (TANF) mothers informing them about the program, (3) presentations to incarcerated fathers participating in a pre-release life skills program, and (4) recruiting from lists of NCPs identified by the Employment Service at the Georgia Department of Labor.

Second, the Fatherhood Connection receives a significant number of referrals from the child support enforcement agency. Noncustodial parents who have not paid child support in over 30 days are required to participate in one of two programs (or they will be sent to a court hearing). "Job-ready" NCPs are referred to a state employment program for NCPs called the Georgia Fatherhood Program. Those that are considered "hard-to-serve" (primarily those without a high school diploma) are required to participate in services at the Fatherhood Connection.

\section{Intake and Assessment}

The County Child Support Enforcement Office determines WtW eligibility for those individuals it refers to the Fatherhood Connection. Staff at the Fatherhood Connection, with assistance from child support staff, determine WtW eligibility for those recruited directly into the program.

The assessment process is intensive and covers a range of issues, including employment and education history, employment goals, family history, and potential employment barriers. Assessment includes the completion of a five-page assessment form identifying employment history and barriers, development of a three-step action plan, and the completion of a personal responsibility contract that requires the participant to establish paternity (if they have not), participate in Fatherhood Connection activities, seek employment, and develop a manageable child support plan. The Test of Adult Basic Education (TABE) is administered to those who have not graduated from high school or gotten a GED. 


\section{Case Management}

Each NCP in the program works with two staff members at the Fatherhood Connection. Job Coaches are responsible for all job-related assistance, including job readiness services, job placement, job retention, and working with employers. Family Advocates focus on intake and assessment and addressing other nonemployment-related issues, including substance abuse, mental health, housing, parenting, and referrals to education and training programs. There are five sets of "teams" - each of which consists of a Job Coach and a Family Advocate. Each team serves a different neighborhood in the county.

The child support enforcement agency hired a consultant who is also actively involved in working with Fatherhood Connection participants. This individual, in collaboration with the Fatherhood Connection case management teams, provides assistance on a range of employment, personal, and family issues for individuals who are referred from the child support enforcement agency.

\section{Employment and Postemployment Services}

Before beginning job search activities, participants attend a three-hour motivational, selfempowerment class that focuses on explaining program services and child support responsibilities. Following the self-empowerment class, individuals are referred directly to their Job Coach, who assists them in initiating a job search (sometimes through accessing services at the Employment Service or the Dekalb Economic Opportunity Authority) and provides referrals for employment leads.

Once individuals find a job, Job Coaches continue to remain in close contact with the individual. They usually contact the client every other week - and are required to contact them once a month to verify employment. Once they are working, in order to promote their career advancement, the Family Advocate is responsible for working with individuals to identify and enroll them in appropriate education and training programs. The program also provides transportation assistance in the form of transit passes or tokens.

\section{Parenting and Relationship Services}

The program makes referrals to peer support, parenting, and other relationship-oriented services on an as-needed basis. Overall, few participants have been using these services. A few referrals have been made to a new statewide program called "Families First," which focuses on resolving access and visitation issues.

\section{Other Services}

On an "as-needed" basis, the Fatherhood Connection makes referrals for substance abuse and mental health issues. 


\section{Contact Information}

Dr. Frederick Zaks

The Fatherhood Connection

3576 Covington Highway

Decatur, GA

(404) 297-0068 


\section{Full Employment Council's Concerned Parent Program Kansas City, MO}

\section{Overview and Local Context}

The Full Employment Council (FEC) is a private, nonprofit organization created in 1986 by the merger of four local employment programs (a program for ex-offenders, a youth program, a reverse-commute urban employment program, and a nonprofit organization that operated Job Training and Partnership Act programs). As the administrator for two Service Delivery Areas (SDAs) and a provider of employment services for FUTURES (Missouri's Temporary Assistance for Needy Families program), it has a long history in workforce development and a good working relationship with the state's Department of Social Services (DSS) (which includes child support enforcement). Implementation of the Welfare-to-Work (WtW) program for noncustodial parents (NCPs) challenged the agency to adapt its usual approach to recruiting program participants, its operational procedures and linkages with DSS at the state and local level, and its successful employment program (characterized by the innovative use of voucher payments to provide substantial job retention incentives to participants) for a population of clients they had not served before.

Some participants in the FEC's Concerned Parents Program (CPP) are also part of the state's Parents' Fair Share (PFS) program, which also provides assistance to NCPs in finding employment and paying child support. The program has developed creative approaches to recruit additional clients - such as the use of two "street recruiters who go where the FEC can't go." The program has several case managers for each participant and emphasizes quick job placement accompanied by self-enhancement after employment. Kansas City is an urban/suburban area, and the program serves a mix of African Americans, Hispanics, and Caucasians.

\section{Lead Agency and Key Partners}

The FEC, PFS, and DSS - particularly the Division of Children and Families and the Division of Child Support Enforcement (for eligibility and [initially] recruitment and referrals)—are the key partners in this initiative.

\section{Funding Source(s) and Enrollment}

A competitive WtW grant funds the NCP program. As of July 2000, a total of 267 participants had entered the program.

\section{Target Group}

The program serves NCPs who meet the WtW eligibility criteria. No specific demographic group has been targeted, although the NCP caseload reflects the low-income population in the area. 


\section{Incentives for Participation}

CPP is a voluntary program. To encourage participation, for those referred through PFS, child support collection can be delayed (though this adds to arrearages) or sanctions postponed (such as the suspension of professional, hunting and fishing, and drivers' licenses) while NCPs are participating in CPP or other education, training, and placement programs.

The employment services and financial incentives for job retention are also important incentives to encourage participation. CPP provides a job retention incentive in the form of vouchers for work-related expenses. They are available at three months (a value of \$300) and nine months (a value of $\$ 1,500$ ) for participants continuously on the same job. At the time of our visit, only one NCP had received the nine-month benchmark voucher.

\section{Outreach and Recruitment Strategies}

NCPs who are unemployed, underemployed (unable to make their full child support payments at their current wage), or have arrearages are referred to the PFS program by the Division of Child Support Enforcement. PFS then refers WtW-eligible individuals to the CPP program. Slightly less than half of the CPP participants are referred by the PFS program. PFS staff are colocated at the CPP program.

In addition to referrals through PFS, the FEC staff members also check applicants and participants in other FEC programs for WtW eligibility and make referrals to CPP when appropriate. In addition, they have just implemented a program using two street recruiters: NCPs themselves who had been clients in FEC programs and who are known in the community because they are local musicians. They "go where the FEC cannot go" to initiate contact and conversations with young men and women who may be eligible for the CPP and to extend friendly invitations to enroll in the program.

\section{Intake and Assessment}

For individuals referred through PFS, the PFS case manager is responsible for determining WtW eligibility and has usually conducted an initial assessment. Whether referred by PFS or from any other source, all individuals must complete an application for the CPP program, and CPP staff complete a one-on-one assessment covering employment and basic personal/family issues. Participants also sign a personal responsibility contract.

\section{Case Management}

The CPP uses a team of case managers. A Career Counselor (CC) at CPP addresses overall needs with attention to personal and family issues. Each participant also meets with an Employment Counselor (EC) who helps with job search, does job development, and works on retention after placement. FEC has now added a third position-a Job Matcher who provides three immediate job referrals to each participant after orientation. Participants use postcards to stay in touch, and they are asked to keep journals to discuss with their CC on a monthly basis. The CC or EC contact them regularly to check on employment and to encourage them to 
undertake self-enhancement activities such as education and training. Those referred to CPP by PFS also continue to work with their PFS case manager on a range of issues-which vary depending on the needs of $\mathrm{NCP}$-including referrals to employment, education and training activities, parenting issues, and child support issues.

\section{Employment and Postemployment Services}

Services include job preparation, resume preparation, provision of job leads, job development, and retention follow-up, including logistical support such as help with transportation (which has represented a large expenditure for the CPP). Job preparation for the NCPs are conducted in three half-day sessions by an experienced educator and coach called a Job Success Instructor. All WtW clients are eligible for the retention incentives described earlier. CPP sometimes refers NCPs to education and training programs, and the program sometimes pays for training. CPP participants can also engage in work experience and on-the-job training, but there is not much interest in these programs among the NCPs.

\section{Parenting and Relationship Services}

NCPs can be referred by their PFS case manager or a CC to a mediation service on visitation issues, unless there is a court order banning visitation. There is one fatherhood program in the area, but only a few referrals have been made to it. Though FEC has focused on employment, some CPP and FEC staff members are exploring ways to incorporate additional services such as parenting, peer groups, and anger management.

\section{Other Services}

All NCPs have access to GED, adult basic education, and Workforce Investment Act training programs. They can also get referrals for substance abuse treatment. In addition, PFS provides additional funding for some services (the PFS program already does a fairly broad assessment, and the scope of its assessments is now expanding).

\section{Contact Information}

Clyde McQueen

President/CEO

Full Employment Council, Inc.

1720 Paseo

Kansas City MO 64108

(816) 471-2330 


\section{Houston Works \\ Houston, TX}

\section{Overview and Local Context}

Prior to the development of the Houston Works (HW) project for noncustodial parents (NCPs), the local Office of the Attorney General (OAG) was looking for ways to improve systems for the collection of child support, to include an emphasis on prevention of arrearages, alternatives to jail, and more father-friendly approaches. When leaders of HW invited an assistant attorney general to visit one of their seven one-stop centers in Houston and to discuss applying for a WtW grant to serve NCPs, he recognized an opportunity to establish the kind of program he and a coalition of organizations had been trying to fund for several years.

Initial recruitment was slow. After the program began operating, however, the OAG and HW approached the IV-D court serving Houston and offered the judges (who hear 90 to 100 child support cases per day, four days a week) an alternative remedy to the threat of incarceration for those who could not meet their child support obligation due to unemployment: help finding and retaining jobs. They agreed to give the program a try, and today the program has forged a strong link between $\mathrm{HW}$, the OAG, and the courts that the assistant attorney general has been asked to replicate elsewhere in the state.

\section{Lead Agency and Key Partners}

HW, created in 1984 as staff to the Private Industry Council serving the City of Houston, operates one-stop career centers and a range of workforce development programs serving disadvantaged residents of Harris County (with a focus on the city of Houston). The OAG for the state of Texas, which operates nine Child Support Enforcement Units in the Houston area, also played a central role in the design and implementation of the partnership. In addition, the Harris County IV-D court system has played an instrumental role in the development of the project and in providing a steady source of referrals.

HW subcontracts with seven local human service agencies to provide assessment, case management, employment and training services, postplacement services, support services, and referral to a range of other services: Educational Learning and Enrichment Center; SEARCH Homeless Project; DSU Training Institute; Houston Community College; Employment and Training Centers; Goodwill Industries; and Refugee Services Alliance.

\section{Funding Source(s) and Enrollment}

The NCP program is funded by a Welfare-to-Work (WtW) competitive grant. Between the start of the grant (June 1998) and July 2000, HW had enrolled a total of 192 NCPs. The overall goal is to serve 510 NCPs through the end of the grant (June 2001). 


\section{Target Group}

Program participation is limited to individuals meeting the WtW eligibility criteria, though HW is able to serve individuals referred by the courts and child support enforcement units who do not meet WtW eligibility criteria through its one-stop career centers (which provide a range of employment services for the general public). Hence, in effect, $\mathrm{HW}$ can provide services and meet the needs of any NCP referred-though more intensive services (e.g., training, referral to subcontractors, and a range of support services) are available for those eligible under WtW.

\section{Incentives for Participation}

Those not coming through the courts or child support enforcement units voluntarily participate in the program. The primary incentives are the employment and retention services that HW and its subcontractors provide.

The IV-D judges can court order participation in the HW program as one of the conditions with which the NCP must comply. (The individual essentially has three alternatives: payment of the delinquent child support, jail, or reporting to HW). A compliance hearing is typically held 90 days later to check to see if these conditions are met-failure to cooperate with HW and not paying child support could be sufficient reason for jailing (for up to six months).

\section{Outreach and Recruitment Strategies}

Eighteen months into the WtW grant, the outlook for success appeared bleak, with only 47 NCPs enrolled. Legislative changes in the WtW eligibility criteria and a link with the IV-D courts (facilitated by provision of an on-site desk at the court where program representatives could make immediate contact with NCPs referred to the program) substantially eased recruiting problems. In addition, HW developed effective literature and promotional materials that have been distributed throughout the community and is now also receiving reverse referrals from its seven employment services vendors. In addition, HW screens its other one-stop clients for WtW eligibility.

HW reports back to the court on whether court-ordered referrals fail to show up for the program. HW does not disclose employment or wage information to the court, however. HW makes it clear that it has no responsibility for collecting child support and wants to avoid that perception on the part of its clients.

\section{Intake and Assessment}

Procedures for enrollment in the program vary, depending on how the individual is recruited. For court-order referrals, a representative of the program is available whenever the court is in session at an office adjacent to the courtroom. This representative tries to immediately engage any individuals who have been court-ordered to $\mathrm{HW}$; these individuals complete a brief information form (so HW can confirm eligibility) and are invited to the next scheduled NCP orientation session. HW is able to check eligibility directly by using the state's integrated 
database system, which it can access because it is a provider for the Workforce Investment Act and CHOICES (Texas's TANF work program).

When individuals are "reverse-referred" by HW vendors, vendors provide identification information that enables $\mathrm{HW}$ to check WtW eligibility. If individuals referred by vendors are WtW eligible, the subcontractor referring the NCP is given the go-ahead to enroll the individual in the program and begin providing services. (Those not $\mathrm{WtW}$ eligible may still receive services from these agencies; depending on their situation and the availability of other funds, however, the services may be more limited.)

HW participants sign personal responsibility contracts or verbally agree to them. Individual employment plans are developed by HW case managers or vendor case managers (with HW sign-off).

\section{Case Management}

When the program began, HW had trouble finding community-based organizations and nonprofits who would agree to provide services for NCPs, because many agencies did not have experience working with them and felt they were an unknown group. Therefore, HW decided to provide employment services itself, through its one-stops, for half of the planned caseload of 510.

HW employs two NCP case managers and is about to hire a third. When clients are referred to employment subcontractors, the HW case manager serves in a secondary capacity, primarily tracking progress of the NCP through the program and signing off on the service plan and changes to it. Each subcontracted agency assigns a case manager to work with an enrolled NCP. HW and the two subcontractors we visited emphasized the case manager working one-on-one with the individual, particularly in job placement, provision of support service or arranging for referral for support services, and troubleshooting problems as they arise.

\section{Employment and Postemployment Services}

Before they would agree to refer NCPs to the program, the courts wanted to make sure that those they referred could be served whether they were WtW eligible or not. Therefore, HW made a commitment to link every referral to employment services. HW could make this commitment because of the resources available in its one-stops.

HW and the two subcontractors we visited emphasize work-first approaches; these include job readiness workshops, job placement assistance, intensive case management, and support services tailored to individual needs. Postemployment services have primarily involved one-on-one case management, including contacts with employers and troubleshooting of problems as they arise.

Short-term training (less than six months) and basic skills instruction (particularly toward obtaining a GED) is made available either directly by WtW subcontracting agencies or through referral arrangements. Relatively few NCPs have been interested in pursuing training, however. 


\section{Parenting and Relationship Services}

The HW program focuses on improving the economic viability of NCPs; other services and goals were seen as incidental. However, all the program partners have become more interested in incorporating resources and services to address other needs such as parenting skills. HW is trying to help a local parenting program qualify as a vendor to HW so it can refer NCPs to the program.

\section{Other Services}

HW and its vendors can and do provide referrals for substance abuse treatment or other services, as well as transportation assistance and even child care.

\section{Contact Information}

Rick Von Frank

WtW Coordinator

Houston Works

600 Jefferson, Suite 300

Houston, TX 77002

(713) 654-1919 (x1167) 


\section{Institute for Responsible Fatherhood and Family Revitalization (IRFFR) Milwaukee, WI}

\section{Overview and Local Context}

The Institute for Responsible Fatherhood and Family Revitalization (IRFFR), headquartered in Washington, DC, received a Welfare-to-Work (WtW) competitive grant to establish grassroots responsible fatherhood programs to serve low-income, noncustodial fathers in several locations: Milwaukee, Wisconsin; Cleveland, Ohio; Nashville, Tennessee; San Diego, California; Washington, DC; and Yonkers, New York. The program provides intensive one-on-one and peer group counseling, as well as a range of other services, to help noncustodial parents (NCPs) to become involved in the lives of their children and provide financial support and security in a loving, compassionate way. IRFFR places strong emphasis on intensive case management and staff role modeling. Outreach Specialists and Managing Partners-who live in the neighborhood and are available 24 hours a day, seven days a week to participants-provide counseling through frequent home visits and also connect participants to needed services and employment opportunities. This site visit summary focuses on the structure of the program as it has been initiated in Milwaukee.

The Milwaukee IRFFR project serves a primarily African American clientele from low-income neighborhoods within the city. While the job market is relatively strong in the Milwaukee area and unemployment at among its lowest levels in many years, pockets of unemployment and underemployment persist within the inner city.

\section{Lead Agency and Key Partners}

IRFFR, a nonprofit organization established in 1982, is the lead agency for project design, startup, and ongoing administration of this initiative. The program in Milwaukee and other cities replicates an earlier (and still ongoing) initiative mounted by IRFFR in Cleveland. In the Milwaukee site, IRFFR provides most services directly and does not have other key subcontracted partners. However, the organization coordinates with other human service agencies (including W-2 agencies), education and training providers, and employers for recruitment and referral for services or employment opportunities.

\section{Funding Source(s) and Enrollment}

IRFFR received a WtW competitive grant to design and implement the project in Milwaukee and several other locations. The Milwaukee site enrolled and served an estimated 300 individuals in the program and placed 176 in jobs in 1999. 


\section{Target Group}

The IRFFR project's target population is primarily low-income and disadvantaged male NCPs, most of whom live within about 15 minutes' drive time of the program office. Once the male NCP is actively engaged in the program, IRFFR seeks to involve (if possible) the custodial parent in the program.

\section{Incentives for Participation}

Participation in the program is voluntary. The IRFFR philosophy embraces the view that a father has the inner capacity to solve his own problems and the role of the program staff is to assist him through a process of self-discovery. The main incentives to participation are one-on-one counseling, group sessions, and referral to job openings and support services.

\section{Outreach and Recruitment Strategies}

IRFFR Outreach Specialists recruit young fathers where they frequently gather in the community, including local stores, recreational centers, basketball courts, and playgrounds. The program office is located within the inner-city community it serves, and Outreach Specialists live within that same community. Fathers are also recruited through staff presentations at schools, churches, and other gatherings of NCPs. IRFFR also provides information about the program to staff at other agencies and programs serving the community (including W-2 agencies and the Department of Corrections) and accepts referrals from these agencies. A significant proportion of NCPs are self-referrals, who hear about the program through friends, relatives, coworkers, and others in the community.

\section{Intake and Assessment}

The IRFFR program is open entry/open exit, with the length of participation typically lasting at least six to eight months (and often longer). The NCP (once enrolled, referred to as a "protégé") decides on his own whether he wants to participate. The core service provided to all participants is a series of in-home, one-on-one counseling sessions. The initial home visits (generally conducted twice a week during the first month) focus on assessment and developing a plan outlining goals the individual would like to achieve. Outreach Specialists use an inductive counseling technique (referred to as "creative questioning"), which enables the father to take an active role in the development of personal goals and in identifying his own resources (for example, personal, family, community) to achieve them. Because there is a strong belief that participants must want to make changes in their lives and that these changes must come from within participants, fathers are encouraged to be self-reliant and not depend on program staff to provide answers to questions.

\section{Case Management}

IRFFR places strong emphasis on intensive case management and staff role modeling. As a condition of employment, staff members are required to model a "risk-free lifestyle" (no drugs or alcohol). IRFFR tries to hire married couples to serve as Managing Partners (program 
administrators) and Outreach Specialists. It is believed that program participants will emulate the married couple's behavior once they see a successful marriage modeled. Outreach Specialists provide counseling through frequent home visits and also connect participants to needed services and employment opportunities.

\section{Employment and Postemployment Services}

IRFFR provides a range of individualized employment services aimed at assisting participants to secure or upgrade employment, including help with resume preparation, job search planning, and job leads. The project maintains close links with several area employers (including UPS) for job placement. IRFFR has a staff member who provides basic instruction on the most frequently used computer software applications. IRFFR also has volunteers who come to the office to provide basic literacy instruction. After participants become employed, IRFFR continues to provide case management services and troubleshooting to guard against job loss and slipping back into destructive lifestyles.

In addition to intensive in-home counseling, IRFFR offers peer group sessions in the evening once a week. Separate sessions are held each week for males and females. Each session, which involves a facilitator and small group discussions among participants, focuses on a particular topic area, such as building self-esteem, fathering skills, health and nutrition, employment, and male/female relationship building.

\section{Parenting and Relationship Services}

The central emphasis of the IRFFR project is on reconnecting NCPs with their children and improving parenting skills. The main intervention is direct, one-on-one counseling by program staff with each participant. At the core of the project is a belief that attitude change leads to other positive consequences, such as greater involvement with children, payment of child support, paternity establishment, and long-term employment. After the NCP is engaged, the program seeks to bring in the custodial parent for individual counseling and peer support groups (separate peer support groups are held for mothers). An important goal of the program is to resolve relationship issues and disputes between the noncustodial and custodial parents, so that the NCP can become actively involved financially and emotionally with the children. IRFFR refers participants to other agencies for paternity establishment, as well as for mediation and legal assistance related to child support and visitation issues.

\section{Other Services}

IRFFR arranges for participants to receive needed support services primarily through other human service agencies in Milwaukee. The organization maintains linkages so that it can refer NCPs for housing assistance, transportation assistance, nonmedical substance abuse treatment, and other services. 


\section{Contact Information}

The Institute for Responsible Fatherhood and Family Revitalization

Milwaukee Office

2451 N. 44th Street

Milwaukee, WI 53208

(414) 873-5068 


\section{Los Angeles County Private Industry Council Noncustodial Parent-to-Work (NCPtW) Program \\ Los Angeles, CA}

\section{Overview and Local Context}

The Noncustodial Parent-to-Work (NCPtW) Program started operating in September 1998. This NCP program grew out of Los Angeles County's Parents' Fair Share (PFS) demonstration. The program provides both pre- and postemployment services to NCPs who are have child support arrearages and who are unemployed or underemployed (working less than 25 hours per week). The program is to serve 1,000 participants over the course of the grant. The program seeks to improve the lives of children by improving parents' means of caring for them financially and by enabling NCPs to take a more active role in their children's lives.

The program serves a primarily minority clientele (approximately 55 percent Hispanic, 35 percent African American, and 10 percent other) from low-income neighborhoods throughout Los Angeles County. Although the economy has been strong and the unemployment rate low, job placement and retention has been difficult due to fear of incarceration for arrearages prior to joining program and drug/alcohol use by a high number of participants.

\section{Lead Agency and Key Partners}

The lead agency is the LA County Private Industry Council (PIC), Department of Community and Senior Services (CSS). Key partners include four additional PICs in the Los Angeles area: City of Los Angeles; Long Beach; South Bay; and Carson-Lomita-Torrance. Other partners include the Department of Public Social Services (DPSS), which provides lists to CSS of General Relief participants who may be eligible for NCPtW services; the Los Angeles County District Attorney's Office (the IV-D agency), which provides lists of NCPs to CSS from which CSS can recruit potential participants; the State of California Employment Development Department (EDD), and The Training Institute (TTI). EDD and TTI have contracts to provide services to program clients.

\section{Funding Source(s) and Enrollment}

The LA County PIC, CSS, received a two-and-one-half-year competitive grant in August 1998 to build on the existing Noncustodial Parent Demonstration (NCP Demo) Program in LA County and continue activities started under the PFS demonstration. Funding includes competitive and formula grants. The program is to serve 1,000 noncustodial parents over the course of the grant-750 through the five partner PICs and 250 through the five community-based organizations that have contracted with the South Bay PIC. As of June 2000, the program has served 418 NCPs. 


\section{Target Group}

Eligible program participants are NCPs of children whose custodial parent is receiving Temporary Assistance for Needy Families (TANF) and has received assistance for 30 months or longer or is within 12 months of reaching the time limit on receipt of assistance. There are approximately 300,000 to 350,000 NCPs in the Los Angeles area available as potential program participants. The show-up rate among those referred has dropped from 90 to 95 percent at the beginning of the program to approximately 80 percent. Approximately 2 out of 12 new participants drop out during the pre-job search stage. There are no financial disincentives or punishments for dropping out of the program.

\section{Incentives for Participation}

Participation is voluntary. In addition to the employment and parenting services provided, participants can work with the IV-D staff to stop their arrearages from mounting while they are in the program.

\section{Outreach and Recruitment Strategies}

DPSS and the LA County District Attorney's (DA's) Office play central roles in the referral and eligibility verification process. The LA County DA's office provides lists of NCPs to CSS, from which CSS can recruit potential participants. DPSS verifies that potential program participants are indeed eligible for the program. DPSS also provides lists to CSS of General Relief participants who may be eligible for NCPtW services. Recruitment is done through public flyers and mailings, job fairs and local program sites, and some word of mouth.

\section{Intake and Assessment}

Each recruited NCP whom DPSS verifies meets the WtW eligibility criteria first goes through an NCPtW orientation lasting about two hours. At the orientation session, recruits complete standard reading and math tests, as well as a short survey about their perceptions of themselves and their relationships with their children. Recruits also complete a Baseline Information Form. Each NCP is then assigned a CSS caseworker and spends the first week in a Peer Support Group and completing additional intake, testing, and assessment forms.

\section{Case Management}

Clients have "case analysts" or "case coordinators." The case analyst or coordinator conducts an initial orientation for all potential clients. This is followed by an assessment by TTI, a private firm contracted to provide employment and case management. EDD provides job development and placement services under a contract with the program. Clients then go through pre-job search activities, which include group counseling with other NCPs and basic skills training (when needed). Clients also sign a Personal Responsibility Contract after determining their goals and needs. This is sometimes referred to as an Individual Service Strategy Plan. 
Meetings called "case staffings" occur when clients miss peer support groups, miss scheduled program services, or are having difficulty with the program overall. The case staffing group includes the case analyst/coordinator, the peer group facilitator, the job developer, job club coach, and the EDD staff member who has worked with the client.

\section{Employment and Postemployment Services}

Employment services begin the first week with a Peer Support Group component, which has sessions three times a week lasting two to three hours. This component is designed to enhance self-image, help identify long- and short-term life and employment goals, and encourage responsible parenting. NCPs then attend a job club lasting seven to nine sessions. The job club is intended to develop job search skills, teach participants how to prepare resumes, improve communication and other soft skills, and increase skills in applying for and interviewing for positions. Participants have access to computers and telephones for resume writing, internet job search, and faxing during this time. For those unemployed at the end of the job club, 30 hours of independent job search per week must be verified.

Postemployment services include clothing, transportation, housing, and, possibly, other services, which may be used for up to six months past initial job placement. On-the-job training has not been used.

\section{Parenting and Relationship Services}

These services are provided primarily through the peer counseling meetings, which are open to all clients, including those who have been placed in a job. Mediation with custodial parents is provided when the NCP requests it. The program does not emphasize custody assistance.

A coparenting program brings the fathers together to learn about nonconfrontational means of communication with the mothers. There is some incentive for the fathers to attend and participate in this program, as it provides a forum for them to share their experiences with and learn from others in similar positions. An attempt has been made to bring the mothers into the program with one another, separately, and with the fathers. The mothers have much less incentive to participate in this program, however, and they generally do not.

\section{Other Services}

There is a domestic violence program, which receives separate funding from TANF and welfare funds specifically for those clients tied to welfare. The program also serves NCPtW and NCP Demo clients. Staff are trained to identify indicators of domestic violence, recognize both abusers and the abused, and refer them to outside agencies for counseling and treatment.

A drug/substance abuse treatment assistance program refers clients to treatment programs and monitors the clients while in the NCPtW program. Program staff are notified by employers when a client tests positive on a drug test on the job. The clients must go through an assessment that can lead to reentry into the program or referral to a drug assistance agency. Clients often do not return to the program. 


\section{Contact Information}

Geraldo J. Rodriguez

Program Manager

Employment and Training/Special Programs

County of Los Angeles Community \& Senior Services

3175 W. Sixth Street, 3rd Floor

Los Angeles, CA 90020

(213) 738-3084

Charles E. Adams

Project Manager

L.A. County Noncustodial Parent-to-Work Program

County of Los Angeles Community \& Senior Services

Centro Maravilla Area Office

4718 Cesar E. Chavez Ave.

Los Angeles, CA 90022

(323) 260-3861 


\section{LA Veterans in Progress Fathers Welfare-to-Work Program Los Angeles, CA}

\section{Overview and Local Context}

LA Veterans in Progress (VIP) was established in 1993 to meet a serious service gap for homeless veterans in the Los Angeles area. Homeless veterans who successfully completed substance abuse or alcohol programs had nowhere to live and no one to provide continued support for them to reenter the world of work. A public-private partnership was formed, with a private for-profit firm owning the facility and a nonprofit organization formed to provide services to the veterans. The goals of the original VIP program are to help homeless veterans become self-sufficient and, when capable, participate fully in the labor market and achieve residential stability and continued sobriety. A component was added in April 2000 for homeless veteran fathers who required fatherhood services, as well as the labor market and social support services provided to the homeless vets already being served under the VIP program. In addition to the goals of the extant program, the fathers program is to provide participants with selfsufficiency and employment, improve their relationship and parenting skills with their children, stop the cycle of fatherlessness, and improve their payment of child support.

\section{Lead Agency and Key Partners}

LA Vets is the lead partner in the program and is responsible for operation of the program. The Veterans Administration (VA) is the largest source of support and provides about 50 percent of the funding; the VA has seven staff on-site. The LA County District Attorney's Office, the IV-D agency, works with the program to provide assistance on child support matters. The state employment security agency, the Employment Development Department, is a service provider and has staff stationed at the program to help participants find employment. The local Workforce Investment Act (WIA) program (formerly JTPA) serves as a funder and grant administrator. AmeriCorps provides a large number of volunteers.

\section{Funding Sources and Enrollment}

The fathers program receives funding from several sources. The VA is the largest source of support and provides about 50 percent of the funding. The second-largest source of support is from the LA County's Welfare-to-Work (WtW) competitive grant, which provides about 20 percent of the program's funding. (This is the same grant that provides support for the LA County noncustodial parent WtW program, but a portion of the money is transferred to the South Bay Private Industry Council which, in turn, provides the funds to LA Vets.) The third major source of funding is from the Ford Foundation's Partners for Fragile Families grant, which provides about 15 percent of the noncustodial father $\mathrm{WtW}$ program support. The remaining funds come from smaller grants and user fees. Participants who work are required to pay the lesser of one-third of their earnings or $\$ 50$ per week for the program. The program started April 1, 2000; as of June 2000, it had 27 participants enrolled. The desired enrollment for the program is 32 participants on board and a total of about 100 served per year. 


\section{Target Group}

The target group for the program is homeless, substance-abusing veteran noncustodial fathers recently released from substance abuse treatment. To be eligible for the program, the participants must have 90 days of sobriety. The program does not serve sex offenders or veterans with less than an honorable discharge from the military. The program serves veterans from the entire Los Angeles County area.

\section{Incentives for Participation}

The program is voluntary. The major incentive for participants to remain in the program is that they are homeless and jobless, and the program offers housing, three meals a day, social services, and a good prospect of obtaining a job (85 percent for the overall VIP program, with no figures available for $\mathrm{WtW}$ yet). Although the program is flexible on length of participation, three violations assure termination: lack of rent payment for working participants, failing a drug test, and violence or verbal abuse.

\section{Outreach and Recruitment Strategies}

The program is constantly conducting outreach activities for the WtW program and the broader VIP program. Over 90 county agencies are contacted on a regular basis, encouraging them to send eligible vets to the program. Major sources of referrals are detox centers, the welfare agency (Department of Public Social Services), prisons, and the Haven (a Salvation Army rehabilitation program). About 25 percent of those referred are believed to come in for eligibility screening. The program makes extensive use of AmeriCorps volunteers for outreach; the volunteers contact the more than 90 source agencies on a regular basis to obtain referrals.

\section{Intake and Assessment}

Upon application to the program, the potential participant is screened for eligibility. Participants must be veterans with an honorable discharge. Virtually all applicants are homeless and recovering substance abusers. During the initial interview, a job history is taken, and applicants are asked why they want to enroll and why they want a job. If accepted, they are tested for drugs and alcohol. Applicants with potential mental health problems may be asked to obtain clearance from a VA mental health official to enroll, and those who need medicine must take their medicine if they wish to remain in the program.

Before starting formal activities, participants engage in community service for 40 hours to show that they are motivated and that they are willing to work for the help and benefits they receive. During Phase 1 of the program, they receive a comprehensive assessment on their literacy level, interests, anger management, self-esteem, and other areas that might affect their needs and activities. They are also asked about their child support status at this time. Participants are asked to sign a personal responsibility contract developed by the program. 


\section{Case Management}

Case managers include certified alcohol and drug counselors, as well as AmeriCorps volunteers, who generally have fewer credentials. Participants are tracked through the daily morning group meetings, where their job seeking activities are monitored, and through weekly activity forms that they fill out. The program director meets with participants who are not making satisfactory progress to provide counseling and issue warnings if needed.

Participants are managed by the director of fathers programs and other case managers. The VA has staff on-site to provide counseling and access to VA services to those in need. The primary means for tracking participants' progress are the daily meetings and the weekly self-progress forms. The program is considering using a computerized management information system to track participants through their stay.

\section{Employment and Postemployment Services}

The program includes both job search and training activities. The Career Center includes program staff, as well as an outstationed state EDD person from the Disabled Veterans Outreach Program. At the daily morning motivational and information sharing meeting, participants indicate employers they have contacted and plan to contact-participants are required to make at least five employer contacts daily. The Career Center includes job developers who identify suitable openings for the participants. Classroom training and basic skills training are provided when appropriate, and work experience is provided to some participants through the VA. Current training programs include customized training programs with Toyota and Marriott, and participants are also enrolled in culinary arts and construction programs. While enrolled in training, participants usually receive minimum wage stipends.

Once participants obtain employment, the program works with them on pursuing education and training to maintain or upgrade their job. The program also encourages participants to plan for the longer term through counseling and meetings.

Key partners in providing employment and training activities are EDD, the local JTPA/WIA onestop, employers involved in customized training (Toyota and Marriott), and the Inglewood Adult School (which provides basic skills training).

\section{Parenting and Relationship Services}

The fathers program started recently, so the parenting program is still evolving. The program offers a series of workshops and group sessions, primarily in the evenings after job search and training have been completed, to deal with life skills and relationship issues such as anger management. Currently, parenting education is covered in an informal course; the staff is concerned that the course will not meet court requirements for fathers ordered to take a course. Topics covered include relationships with the custodial parent and the child, appropriate methods of disciplining the child, and dealing with the child support system. Fathers are assisted individually with child support issues, such as dealing with restraining orders and improving access and visitation arrangements. The program does not offer formal mediation services. 


\section{Other Services}

What sets this program apart from other WtW programs is that it is a residential program. Participants live on-site in dormitory-style suites. If employed, they pay the lesser of $\$ 50$ per week or one-third of their earnings for housing. In addition, participants who terminate are eligible for transitional housing at the same site. The VA has people on-site who provide counseling and other VA services. Participants have medical services covered through the VA, but most of these services are provided off-site at VA facilities.

\section{Contact Information}

Steve Peck

Director

733 South Hindry

Inglewood CA, 90301

(310) 348-7600 x3106 


\section{Milwaukee County Private Industry Council Milwaukee, WI}

\section{Overview and Local Context}

The Private Industry Council (PIC) of Milwaukee County received a Welfare-to-Work (WtW) competitive grant to design and implement a collaborative project to target and serve noncustodial parents (NCPs). The program seeks to enhance employability, job retention, and capacity to pay child support. The original design for the initiative was based on the health maintenance organization model. The design called for service providers to receive a capitated amount to support and place participants in employment. The program refers NCPs to five community-based organizations for job placement, retention, training, and a wide range of support services.

\section{Lead Agency and Key Partners}

The PIC of Milwaukee has taken the lead role in project design, start-up, and ongoing administration. The PIC has contracted with five local social service agencies to provide direct client services: Human Services Triangle, Wisconsin Correctional Services, United Migrant Opportunity Services (UMOS), New Concepts Self Development Center, and Curtis and Associates. In addition, the PIC has contracted with five Wisconsin Works (W-2) agencies to conduct WtW eligibility determination and entry of client data into the state's automated data system: Employment Solutions of Milwaukee (affiliated with Goodwill Industries); UMOS; Opportunities Industrialization Center of Greater Milwaukee; YW Works; and Maximus.

\section{Funding Source(s) and Enrollment}

The PIC of Milwaukee received a WtW competitive grant to design and implement the program. Under the competitive grant, which initiated contracts with service providers in January 1999, a total of 261 NCPs had been enrolled and served through October 1999. The goal of the program is to serve a total of 500 NCPs (through December 2000).

\section{Target Group}

The target group for the project is NCPs meeting the WtW eligibility criteria. However, each of the subcontractors targets services to specific NCP subpopulations: UMOS targets Latino NCPs; the Wisconsin Correctional Services targets NCPs with criminal justice histories; New Concepts primarily targets African American NCPs with family and mental health issues; and the Human Services Triangle targets NCPs with mental illness or substance abuse issues.

\section{Incentives for Participation}

The main incentives for participation are the wide range of employment, training, education, and support services available to each participant. Participation in the program is generally 
voluntary, though some NCPs are referred to the program through courts (and the Children First initiative), in which case participation is usually mandatory.

\section{Outreach and Recruitment Strategies}

Referrals to the program come from a variety of sources, including the Family Courts, the Children First initiative, W-2 agencies, and the Wisconsin Department of Corrections. A Childrens First/WtW Coordinator at the W-2 offices identifies NCPs that could potentially benefit from the various employment, training, and support services available through the initiative and makes referrals to subcontractors. In addition, the five subcontracting agencies conduct some of their own outreach and recruitment activities, including placing advertisements in local media and conducting recruitment at community gatherings. The state's child support enforcement office made lists of NCPs available to the five subcontracting agencies to facilitate their recruitment activities. One subcontractor (UMOS) indicated that it had hired a full-time outreach staff person to identify and recruit NCPs and was also advertising the availability of its services for NCPs on television and radio and in newspapers.

\section{Intake and Assessment}

The five W-2 agencies serving Milwaukee conduct eligibility determination under the project. Each of these agencies has a small contract to determine eligibility of NCPs for the subcontracting agencies (except for UMOS, which is a W-2 agency) and to enter data on NCPs enrolled under the competitive WtW grant into the state's CARES system. Once the NCP is determined eligible, the subcontracting agency is responsible for conducting an initial assessment and assigning a case manager to each NCP. Though assessment procedures vary across subcontracting agencies, in general, an agency case manager conducts a one-on-one interview with the participant aimed at developing an individual service plan, including collecting information on participant/family background characteristics, vocational interests and preferences, health status (including substance abuse issues), work history and skills, intellectual capabilities/aptitudes, reading/math skill levels, interpersonal/communication skills, and other factors affecting employability and parenting skills. Based on this assessment, the case manager is responsible for developing an individual service plan summarizing personal and vocational goals, identifying employability issues/barriers to success, and recommending specific services to achieve employment and parenting goals.

\section{Case Management}

Each subcontractor is responsible for assigning NCPs to a case manager responsible for coordinating individualized services to achieve a set of planned outcomes (generally centering on employment, job retention, and payment of child support). The case manager is responsible for planning and arranging services and closely tracking participant involvement in the program. 


\section{Employment and Postemployment Services}

The services provided through the subcontracting agencies have a clear work-first focusemphasizing job placement, job retention, and wage enhancement-particularly at the time the individual enters the program. The initial goal is full-time or part-time work at any wage. The program also emphasizes NCPs working so that they can meet their child support obligations. Each subcontracted agency has considerable flexibility to develop its own program strategies, and each of the five agencies has its own special focus. The five subcontracting agencies are permitted to subcontract services to other community-based organizations.

The target population is primarily interested in services that facilitate job placement. Hence, there is a strong emphasis on providing job readiness and placement assistance (including job readiness workshops, help with resume preparation and interview skills, and help with job leads). For example, one of the five subcontracted agencies-Curtis and Associates-receives a benchmark payment of $\$ 4,800$ for each NCP it serves but is placed at risk for job placement and retention. If the agency is able to quickly place the individual into employment and retain them in employment after 30 days, the agency makes money. If the agency is unable to find employment for the individual, however, it must place the participant in a community service job and pay the participant minimum wage (until the participant is placed in an unsubsidized job).

After participants are placed in jobs and paying child support, the service providers are to focus program services on occupational skills training. Each vendor is required to offer one or more employer-linked occupational skills training program for NCPs (for example, through the Milwaukee Area Technical College). With job retention and upgrading posing major challenges for many NCPs, the five subcontracting agencies provide an array of postemployment services, including frequent employer and client contacts, provision of support services, and assistance with upgrading basic and job-specific skills to enhance employability.

\section{Parenting and Relationship Services}

The main focus of the initiative is on employment, though subcontracting agencies are encouraged to provide services that will help improve parenting. To improve parenting skills, case managers are expected to provide informal support, guidance, and direction to NCPs regarding parenting concerns and challenges. In addition, under the competitive grant, the PIC has contracted with Legal Action of Wisconsin so that WtW-contracted agencies can make referrals of NCPs for services. Some of the legal issues that Legal Action of Wisconsin can provide assistance on are driver's license revocations, evictions and housing matters, child support, custody issues, visitation, family violence, restitution, probation violations, correction of criminal records, and consumer debt problems.

\section{Other Services}

The five subcontracting agencies provide (directly or through referral arrangements with other agencies) a range of support services to assist participants in obtaining and keeping jobs and paying child support. These services include transportation assistance (for example, car repairs and transportation vouchers), referral for nonmedical substance abuse counseling/treatment, 
provision of work-related clothes and equipment, and referral to a wide array of legal services (related to child support and visitation issues).

\section{Contact Information}

\section{Delores Parr}

PIC of Milwaukee County

101 W. Pleasant St., Suite 200

Milwaukee, WI 53212

(414) $225-2360$ 


\section{Minneapolis FATHER Project \\ Minneapolis, MN}

\section{Overview and Local Context}

The Minneapolis FATHER Project was developed through a strong collaboration between the city's Private Industry Council (PIC), child support agency, and several community-based organizations. This program, operating in a locality that has developed an array of fatherhood programs, was initially developed and funded under the Ford Foundation's Partners for Fragile Families (PFF) initiative. The FATHER Project subsequently applied for and received a WtW competitive grant to enhance the employment services provided through the program. The FATHER Project is committed to providing a holistic set of program services focusing on parenting, fatherhood, and family issues, as well as on employment. With ongoing communication and assistance from local child support staff, it also provides assistance with child support issues and payment options for participants and views this as a critical component of the program. The FATHER Project is a voluntary program, and participants are recruited through a range of community outreach efforts. It serves a primarily African American clientele from low-income neighborhoods in Hennepin County (which includes the city of Minneapolis).

\section{Lead Agency and Key Partners}

Way-to-Grow (WTG), a nonprofit community-based organization, is the lead agency for the Minneapolis FATHER Project. WTG also assists single mothers with child development and parenting for pre-schoolage children, housing, and medical issues; it was selected as the lead agency because the services for NCPs were seen as complementary to those provided to custodial mothers. The Welfare-to-Work (WtW) grantee- the Minneapolis Employment and Training Program (METP, the Minneapolis Workforce Board)—provides employment services for the program through contracts with eight community-based organizations. The Hennepin County Collection Services Division (HCCSD) conducts eligibility determinations and offers a wide range of child support modifications for program participants.

\section{Funding Source(s) and Enrollment}

The FATHER Project is funded by a WtW competitive grant, a grant from the Ford Foundation, and federal child support dollars (provided as a match to Ford Foundation funds as part an approved waiver program). The program began operating in January 1999; as of May 2000, the program had enrolled approximately 100 individuals. 


\section{Target Group}

The program initially served NCPs who met the WtW eligibility criteria and who also had a child support order in place in Hennepin County. More recently, since it has received funds from the Ford Foundation, it is recruiting the target group for this program-young fathers (ages 16 to 25) with no child support orders (but who also meet the WtW eligibility criteria).

\section{Incentives for Participation}

Participation in the FATHER Project is voluntary. The program offers a wide range of assistance on child support issues, as well as comprehensive set of services to encourage program participation. Child support incentives offered include delays in setting child support orders for 90 days after a participant finds a job, modifying child support orders to reflect fluctuating income, gradually increasing orders to enable the NCP to become accustomed to paying child support, establishing paternity at no cost, waiving the payment of birthing expenses, stopping interest on arrearage payments, and lifting penalties for nonpayment (such as license suspensions, passport denials, and student grant holds).

\section{Outreach and Recruitment Strategies}

The FATHER Project recruits potential program participants directly from the community and uses a number of strategies to identify potential participants. Recruitment was initially difficult, and significant staff time and resources were dedicated to this effort. Flyers, posters, and other materials on the program are distributed to a range of agencies, including job banks, prenatal clinics, Temporary Assistance to Needy Families (TANF) agencies, the Women, Infants, and Children (WIC) program, the child support office, family courts, the corrections department, and community-based organizations. Staff also make presentations at a number of these programs, and WTG sponsored a large community picnic to promote the program. Ads are placed in local newspapers and on radio stations frequently used by the target group. Finally, the program initially used "reverse referrals" by providing financial incentives to employment service contractors for recruiting eligible NCPs. Gradually, the program has built a reputation for helping fathers, and the participating agencies feel that word-of-mouth is spreading in the communities they are targeting.

\section{Intake and Assessment}

NCPs who learn about the program through recruitment efforts call WTG. An initial phone screen is conducted to determine if the NCP appears to be eligible. An eligible NCP is scheduled for a meeting to complete an eligibility form. This is faxed to HCCSD to verify eligibility (TANF and status of child support payments).

Those who are eligible for the program meet with a WTG case manager for an assessment. Assessment is done through a one-on-one meeting with the case manager. The assessment process is intensive and covers a range of issues, including employment and education history, employment goals, family history, and potential employment barriers. 
The individual is referred to an employment counselor at one of the contracted employment service providers (the provider is generally selected based on participant convenience). In the initial meeting with the employment counselor, the individual signs a personal responsibility contract that details the NCPs responsibilities in the program. These include participating in WTG parenting services by attending all scheduled activities, cooperating with Hennepin County child support and collections, maintaining employment (if applicable), monthly contact with job counselors, and job search activities.

\section{Case Management}

The FATHER Project provides intensive case management services, with staff at two organizations providing assistance to each program participant. First, employment counselors at the employment service providers are responsible for all job-related assistance, including job readiness services, job placement, job retention, referrals to education and training, and working with employers. Second, case managers at WTG are responsible for intake and assessment and assistance with a range of other issues that may affect an individual's ability to participate or become employed and pay child support, including parenting and family problems or other personal issues, such as substance abuse. WTG case managers and program participants also work with HCCSD staff to make child support payment options available to participants.

\section{Employment and Postemployment Services}

Employment services for NCPs are provided by eight community-based organizations under performance-based contracts with METP. Specific services vary by provider, but there is a strong focus on immediate employment. Services provided include job placement, job readiness, job search assistance (job leads and resume writing), and job development. Education, training, and on-the-job training programs are available, but few NCPs use these options because most have an interest in finding jobs quickly. Staff at both the employment service provider and WTG maintain close contact with an individual after they begin working to address retention issues. Some employment service providers worked closely with employers to identify appropriate jobs for their participants and to resolve issues that arise once the NCP starts working.

\section{Parenting and Relationship Services}

The FATHER Project has a strong emphasis on parenting services. Peer support/parenting groups are provided by WTG twice a week using a curriculum developed for the PFF demonstration. WTG case managers also address parenting issues in their contacts with NCPs and hold a monthly father-child or family event each month for those who want to participate. Referrals are made for mediation services if necessary, although few NCPs have used these services.

WTG employs a part-time staff person to assist NCPs on legal issues concerning visitation and custody. This includes the operation of a law clinic where 14 volunteer attorneys provide general advice on these issues-including how to represent yourself without the assistance of an attorney. 


\section{Other Services}

Referrals are made to outside organizations for a range of services, including anger management, substance abuse, and mentoring, on an as-needed basis. Few NCPs have used these services. $\mathrm{WtW}$ funds are also available to meet short-term emergencies or needs.

\section{Contact Information}

Deb Bahr-Helgen

Welfare-to-Work Program

Minneapolis Employment and Training Program

250 South 4th Street, Room 510

Minneapolis, MN 55415-1372

(612) 673-3938 


\section{Nevada Business Services \\ Las Vegas, NV}

\section{Overview and Program Context}

This program focuses on enhancing employment outcomes, self-sufficiency, and payment of child support for noncustodial parents (NCPs) located in a four-county area of the southern half of Nevada (with most participants located in Las Vegas). Although the two main contractorsNevada Partners, Inc. and Services Project 2000 - have considerable flexibility in how they structure their programs, the main focus is on getting participants into a job, having them retain employment, and, if possible, enhancing possibilities for increased earnings. Parenting skills are not a focus of this initiative, though one of the two service providers includes several workshop sessions (as part of its job readiness course) devoted to parental responsibilities.

\section{Lead Agency and Key Partners}

There are several key partners in this project. The main organization providing funding and overseeing the effort is Nevada Business Services (NBS), which is the workforce investment board serving a four-county area of southern Nevada. NBS, a nonprofit agency located in Las Vegas, has contracted with two nonprofit organizations to provide services under the Welfare-toWork (WtW) program for noncustodial parents (NCPs): Nevada Partners, Inc., and Services Project 2000 (formerly known as Camino Al Futuro). A third organization-Clark County Social Services-was also contracted under the WtW-NCP project, but after one year withdrew as a provider because of low referral activity. NSB receives WtW formula funds from the state and is primarily responsible for selecting contractors; broadly defining the scope of work and contractor goals for enrollment, job placement, and retention; overseeing contractor performance; and providing technical assistance. The other partner in the project is the Nevada State Welfare Division (NSWD) of the state's Department of Human Resources. NSWD is primarily responsible for referral of NCPs to the program and for WtW eligibility certification of individuals "reverse referred" by the two WtW contractors.

\section{Funding Source(s) and Enrollment Levels}

This project is funded using WtW formula funds. NBS (as the workforce development agency) has received two allocations of WtW funds from the state: (1) a PY 1998-1999 allocation of \$2.47 million, and (2) a PY 2000-2002 allocation of \$2.3 million. As of the end of June 2000, only the first allocation had been contracted; no funds under the second allocation had been contracted out to services providers. As of June 30, 2000, a total of 104 NCPs had been referred for services to the WtW contractors; a total of 70 of these NCP had received services beyond initial assessment. The overall goal is to provide services for a total of 113 NCPs over the twoand-a-half-year period of the grant. 


\section{Target Group}

The overall target group for the program is NCPs meeting the WtW eligibility criteria. Nevada Partners serves nearly all male NCPs (over 90 percent are male), mostly African American males in their 30s and 40s. About half of these NCPs are ex-offenders; many are substantially in arrears on their child support payments (in excess of $\$ 50,000$ ).

Project Services 2000 further limits participation to female NCP offenders soon to be released (within the six months) from the South Nevada Women's Correctional Facility (a minimum and maximum security prison, with 560 female inmates), two-thirds of whom are African American and most of whom are in their 20s. Project Services 2000 limits intensive services to this prison facility, though provides job placement assistance to a small number of WtW-eligible NCPs referred directly by NBS. Project Services 2000 is also considering expanding its program to a men's facility (the Indian Springs Correctional Facility) but plans to do so under the second funding allocation.

\section{Incentives for Participation}

The program is voluntary, and program administrators try to emphasize that the program will help the NCP in several important ways-enhance long-term employability, build job-seeking skills, enhance basic and job specific skills, help the individual to avoid jail, provide assistance with modifying child support payments, and provide help with increasing visitation.

\section{Outreach and Recruitment Strategies}

The recruitment approach for the program has shifted over time to rely primarily upon "reverse referrals"-NCPs who are first identified by contractors and later certified by NBS (and the NSWD) as WtW-eligible. In addition, small numbers of individuals are still being referred through NSWD to the program. The main way that the contracting agencies have obtained referrals is by identifying NCPs on their own and then checking with NBS as to whether the individuals identified are $\mathrm{WtW}$ eligible. Nevada Partners receives some referrals of WtWeligible NCPs directly from NBS. However, most referrals come through reverse referrals, whereby the agency identifies potentially eligible NCPs. Nevada Partners conducts an orientation session at its own facility three times a week for the general public and individuals referred by other agencies.

The Services Project 2000 directly recruits offenders during the two weeks prior to running its eight-week Vital Skills workshop. Prison personnel place brochures about the program throughout the prison facility, notifying prisoners of the startup of a new session.

\section{Intake and Assessment}

Both of the contractors provide a brief, up-front assessment and intensive, ongoing case management services. Once WtW-eligibility is certified though NBS, Nevada Partners schedules the NCP for a one-on-one interview. During this interview, information is collected from the individual that is used to develop an individual service strategy (ISS). No formal tests 
(for example, the Test of Adult Basic Education, interest inventories, or drug/alcohol tests) are conducted as part of the assessment. The ISS is submitted to NBS at the end of the assessment, and, at this point, the NCP is considered enrolled in the program.

Services Project 2000 conducts assessment activities as part of its initial activities in the eightweek Vital Skills Project Workshop. On the first day of the workshop, a general orientation is provided, followed by assessment and completion of ISS. The assessment involves a one-on-one interview with one of the two workshop facilitators. The project receives considerable background information on each participant from the prison. The ISS is completed during this one-on-one interview, which generates additional background information. In addition, the participant completes a questionnaire that probes drug/alcohol abuse issues. The ISS is submitted to NBS at the end of the assessment, and, at this point, the NCP is considered enrolled in the program.

\section{Case Management}

Both contractors emphasize case management services tailored to individual needs of the participant. Both programs assign a case manager to each enrolled NCP, who monitors progress and troubleshoots problems, helps with job upgrading and retention, and arranges for support services. Services Project 2000 features intensive case management-its case managers are available 24 hours a day, seven days a week, once the individual is released from prison. Both programs indicated that they accompanied participants to child support enforcement hearings.

\section{Employment and Postemployment Services}

Employment and postemployment services for NCPs are provided by the two contracted agencies. Both providers emphasize work first approaches, which include a job readiness workshop, job placement assistance, intensive case management, and support services tailored to individual needs.

Nevada Partners divides participating NCPs into two basic groups after assessment- those who are immediately job ready (a relatively small proportion of NCPs) and those who are not job ready. Those who are job ready attend a four-hour job readiness workshop and then are immediately engaged in job search activities (with considerable help from an agency case manager in identifying job openings). The job readiness workshop primarily focuses on effective job search strategies, development of a resume, and interview skills. An agency case manager regularly meets with the individual to gauge progress, troubleshoot problems, arrange for support services, and provide encouragement and job leads. The agency helps to match each client's skills with potential employer openings.

Those NCPs who are not immediately job ready (the majority of participants) are enrolled in two-week job readiness workshop operated by Nevada Partners, called Career Quest. NCPs enrolled in the project are mixed in with other disadvantaged individuals (both male and female, including Temporary Assistance for Needy Families [TANF] and non-TANF recipients) to form a workshop group of between 10 and 15 individuals. The employability skills workshop, led by a Nevada Partners instructor each morning, includes sessions on goal setting, building self- 
esteem, managing conflict, effective job search strategies, resume preparation, interviewing, and employers' expectations. At the conclusion of this workshop, participants work closely with a case manager and engage in intensive job search activities (see above discussion for those who are job ready).

Nevada Partners maintains close relationships with local employers, particularly those within the hotel/gaming industry. For example, individuals interested in entering careers at local hotels and in restaurants can be referred to the Culinary Union Training Center. This training center, formed by the Las Vegas hotels and the Culinary Union, offers classes for people who want to work in a hotel but do not have the required job skills or work experience.

Project Services 2000's NCP program's main intervention is an eight-week, 32-session Vital Skills Project Workshop. This workshop follows a curriculum designed by the Life Skills Foundation, Inc., located in Tampa, Florida. Each participant receives a workbook (over 200 pages long) divided into a series of 15 lessons. Workshop sessions, which are facilitated by two Project Services 2000 instructors, focus on life skills, self-esteem, anger management, effective communication, and motivation. There are also sessions on family success and relationships, as well as on getting and keeping a job. Sessions require active involvement of participants and a willingness to change. At the end of the eight-week session, participants are given a "diploma of life" at a special ceremony.

This workshop is followed up by weekly peer group sessions until the individual is released from prison. As the release time approaches, Project Services 2000 program staff provide assistance with identifying job leads and intensive case management. Project staff have extensive contacts with local employers. (These include employers in the hotel and gaming industry; however, most ex-offenders face constraints on the types of jobs that they may take within the gaming industry, especially if the individual must handle money.) After an individual is employed, the assigned case manager is available 24 hours a day, seven days a week to troubleshoot problems and arrange for services.

\section{Parenting and Relationship Services}

As part of the Life Skills Workshops run by Services Project 2000, 3 of the 15 modules in the curriculum focus on family: "Family Success," "Family Relationships," and "Inter-Family Understanding and Communication." Both projects can refer individuals for legal or mediation

services. On occasion, case managers will accompany individuals to child support court hearings to provide testimony of the level of participation of individuals in programs.

\section{Other Services}

Both service providers under the project provide an extensive array of support services, either directly or through referral arrangements. These services include transportation assistance, including bus passes, and help with car repairs; clothing, including payment at discount stores and secondhand stores for work clothing; referral for substance abuse counseling and treatment; and referral to mediation and legal services for child support and visitation. 


\section{Contact Information}

Richard Blue, Executive Director

Nevada Business Services

920 West Owens

Las Vegas, NV 89106

(702) 638-8750 


\section{Wisconsin Department of Corrections NOW Program Milwaukee, WI}

\section{Overview and Local Context}

The Wisconsin Department of Corrections (DOC) received a three-year grant from the Governor's Welfare-to-Work (WtW) 15 Percent Discretionary funds to design and implement the Non-Traditional Opportunities for Work (NOW) Program in Milwaukee County. The NOW program-which targets noncustodial parents (NCPs) on probation or parole-is closely connected with the Wisconsin Works (W-2) system, with most employment, training, and support services under the program being provided through five W-2 agencies (at their 13 job centers in Milwaukee County). The program seeks to enhance employability, job retention, and capacity to pay child support, as well as to reconnect noncustodial fathers coming out of prison with their children.

Like many prison systems across the country, Milwaukee's prisons are crowded. As a result, probation and parole agents have large caseloads, which leaves little time available to each assigned case. The NOW Project offers additional services to complement those available through the correctional system, with a special focus on employment, job retention, and support services. Because of a relatively tight labor market, current conditions for finding a job for exoffenders are as good as they have been in a long time-yet ex-offenders face significant hurdles and biases when seeking and trying to hold jobs.

\section{Lead Agency and Key Partners}

The Wisconsin DOC's Division of Community Correction has taken the lead role in project design, start-up, and ongoing administration of NOW. DOC has assigned ten probation and parole agents (NOW agents) to case manage NOW participants throughout their involvement in the program. The Wisconsin Department of Workforce Development (DWD), which has overall responsibility for administration of employment, training, and welfare programs in the state (including welfare reform and the JTPA program), assisted with the design of the initiative and determines WtW eligibility for potential NOW participants. DOC contracts with five Wisconsin Works (W-2) agencies to provide case management, employment, training, parenting, and other support services for NOW participants. The five W-2 agencies are Employment Solutions of Milwaukee (affiliated with Goodwill Industries); United Migrant Opportunity Services (UMOS); Opportunities Industrialization Center of Greater Milwaukee; YW Works; and Maximus.

\section{Funding Source(s) and Enrollment}

The Wisconsin DOC received a three-year grant from the Governor's WtW 15 Percent Discretionary funds to design and implement the NOW Program in Milwaukee County. The Governor's discretionary funds are being matched by DOC. The program began enrolling its first participants in April 1999; through June 2000, the program had enrolled and served a total of 130 NCPs. 


\section{Target Group}

NOW targets NCPs on probation or parole or who are soon-to-be-released inmates of minimum security correctional facilities. While initially the program planned to serve only noncustodial fathers, enrollment in the program was recently extended to noncustodial mothers on probation or parole (though few have been served to date). NOW targets only those NCPs who are still subject to DOC field supervision and will be subject to supervision long enough to allow them to complete the NOW program while still under supervision. NOW excludes NCPs if participation in the program poses a threat to the custodial parent or other family members (for example, domestic violence offenders are excluded unless the custodial parent is aware of and agrees to the NCP's participation in the program).

\section{Incentives for Participation}

The main incentives for participation are the wide range of employment, training, education, and support services that are made available to each participant. NOW participation is voluntary, though once enrolled in the program participation in NOW activities becomes mandatory (a condition of probation or parole). Despite being "mandatory," it is unlikely that a NOW participant would have his or her probation or parole revoked solely on the basis of noncompliance with the NOW program (it would take some other violation of the conditions of parole or probation, such as a new offense for re-imprisonment).

\section{Outreach and Recruitment Strategies}

The NOW program recruits most NCPs through direct referrals by regular DOC probation and parole agents. DOC probation and parole agents (estimated at about 350 agents in Milwaukee County) are asked to identify from their caseloads individuals who potentially meet the WtW eligibility criteria and would likely benefit from participating in the program. When recruitment lagged during the early stages of the program, DOC introduced several new strategies to spur recruitment. These include: (1) introducing NOW at orientation sessions for new probationers/parolees, (2) reviewing the caseloads of each agent and identifying individuals who are NCPs and WtW-eligible based on data provided by DWD, (3) placing additional posters about the program in the DOC facilities, (4) encouraging W-2 agencies to recruit ex-offenders and qualify them for NOW participation ("reverse referrals"), and (5) increasing awareness of parole and probation agents about services available through NOW.

\section{Intake and Assessment}

Once potential NOW participants are identified, probation and parole agents complete and forward a referral form to the NOW project coordinator. The NOW project coordinator compiles a list of referred NCPs and sends the list to DWD for WtW eligibility determination. While WtW eligibility is being checked by DWD, the recruit is scheduled for and takes the Test of Adult Basic Education. NCPs determined to be WtW-eligible are re-assigned to the caseload of one of 10 probation and parole agents who are specially assigned by DOC to serve as NOW probation and parole agents (also referred to as NOW case managers). 
Once eligibility for WtW is determined, the NOW probation and parole agent refers WtWeligible NCPs to one of the five W-2 agencies (based on a geographic match of the participant with a W-2 agency). W-2 agency staff conducts an initial intake interview and enrolls the individual with the agency. The individual becomes officially enrolled in the NOW program when the W-2 agency enters case information into the state's CARES data system. Though assessment procedures vary across W-2 agencies, in general, a W-2 case manager conducts a one-on-one interview with the participant aimed at developing an individual service plan. The interview includes collecting information on participant/family background characteristics, vocational interests and preferences, health status (including substance abuse issues), work history and skills, intellectual capabilities/aptitudes, reading/math skill levels, interpersonal/communication skills, and other factors affecting employability and parenting skills. Based on this assessment, the W-2 case manager is responsible for developing an individual service plan summarizing personal and vocational goals, identifying employability issues/barriers to success, and recommending specific services to achieve employment and parenting goals.

\section{Case Management}

Each NOW participant has two case managers - a DOC/NOW parole and probation agent and a $\mathrm{W}-2$ agency case manager. The DOC/NOW parole and probation agent retains final decisionmaking authority on services provided and sanctioning of the participant (revocation of probation or parole status, as well as other sanctions). W-2 agencies assign each incoming participant to a W-2 case manager or counselor, who is responsible for planning and arranging services and closely tracking participant involvement in the NOW program. The DOC/NOW probation and parole agent and the W-2 case manager negotiate and reach agreement on the service plan and subsequent changes in the plan. The W-2 and DOC/NOW case managers typically talk at least weekly about the progress of each NOW participant and work together to ensure that NOW participants receive the services needed to make a successful transition back to their communities.

\section{Employment and Postemployment Services}

The services provided through the W-2 agencies have a clear work first focus-emphasizing job placement, job retention, and wage enhancement-particularly at the time the individual enters the program. Services closely parallel those being provided for Temporary Assistance for Needy Families recipients under other welfare reform programs administered by the W-2 agencies. Each W-2 agency has considerable flexibility to develop its own program strategies, so there is some variation across agencies in the types of employment and postemployment services provided to NOW participants. The target population, most of whom have recently been released from prison, is primarily interested in services that facilitate job placement. Hence, there is a strong emphasis among all W-2 agencies on providing job readiness and placement assistance (including job readiness workshops, help with resume preparation and interview skills, and help with job leads). Although in less demand by the target population, W-2 agencies also make available (as appropriate) short-term, career-focused job skills training (for example, through the Wisconsin Technical College Systems and the University of Wisconsin-Extension Program). W-2 agencies also provide basic computer skills training and referral to basic 
education and remediation programs (for example, area literacy councils, Even Start Family Literacy Programs). W-2 agencies have links with the employer community for subsidized jobs and on-the-job training opportunities. W-2 agencies can also refer participants back to DOC for work experience opportunities under DOC's Community Corrections Employment Program or the Wisconsin Conservation Corps program. With job retention and upgrading posing major challenges for many ex-offenders, W-2 agencies provide an array of postemployment services, including frequent employer and client contacts (especially to troubleshoot problems before they lead to job loss), provision of ongoing support services (such as help with car repair and bus tickets), and assistance with upgrading basic and job-specific skills to enhance employability (e.g., basic education, English as a Second Language, and occupational skills training).

\section{Parenting and Relationship Services}

Two of the five W-2 agencies have implemented parenting/fatherhood program components, and the other W-2 agencies are planning or implementing these components. Employment Solutions offers a comprehensive, 26-session parenting/fatherhood workshop for NOW participants (using a formal curriculum entitled Fatherhood Development: A Curriculum for Young Fathers). Workshop sessions cover topics such as values, manhood, understanding the child support system, understanding children's needs, coping as a single father, male/female relationships, men's health, and substance abuse issues. UMOS also offers a ten-session workshop, entitled "Survival Skills for Men." The small-group workshop sessions (three hours each, held twice a week) cover topics such as budgeting, parenting, health, grooming/dressing, and a range of other topics.

\section{Other Services}

W-2 agencies provide (directly or through referral arrangements with other agencies) a range of support services to assist participants in obtaining and keeping jobs and making the transition from incarceration. These services include transportation assistance (for example, car repairs and transportation vouchers), referral for nonmedical substance abuse counseling/treatment, provision of work-related clothes and equipment, and referral to legal services (related to child support and visitation issues). The specific services provided depend upon participant needs.

\section{Contact Information}

Ms. Margaret Browder

Field Supervisor and Coordinator

State of Wisconsin Department of Corrections

Division of Community Corrections

1819 E. Kenilworth Place

Milwaukee, WI 53202-1119

(414) 227-4399 


\section{Yakima SHARE Project Yakima, WA}

\section{Overview and Local Context}

The Support Has A Rewarding Effect (SHARE) project was developed through a strong collaboration between the local workforce council, the child support agency, the Prosecuting Attorney's (PA's) office, and several community-based organizations. Developed as a direct result of the Welfare-to-Work (WtW) grants program, the SHARE program is one component in Yakima's larger WtW program. The SHARE program features a strong role for both the child support agency and the PA's office. Referrals to SHARE are initiated by the child support office, which identifies individuals who are behind in child support payments. Eligible cases are referred by the child support agency to the PA's office to initiate contempt proceedingsindividuals who are unemployed can choose to participate in SHARE instead of facing incarceration. The goal of SHARE is for the noncustodial parent (NCP) to begin, resume and/or increase child support payments, encourage parental responsibility, and strengthen families.

\section{Lead Agency and Key Partners}

The WtW grantee-the Tri-County Workforce Development Council-played a lead role in establishing the collaboration and overseeing program development and implementation. The Division of Child Support at the Department of Social and Health Services is responsible for identifying potential program participants and referring them to the PA's office. Because of its experience in working with disadvantaged adults and a WtW service provider, People for People (PFP), a nonprofit community-based organization was selected as the primary provider of the employment services. PFP contracts with the workforce council to provide employment services to all types of WtW participants (including NCPs) in five locations.

SHARE is funded primarily through $\mathrm{WtW}$ formula funds. SHARE has now expanded it's partnership to include other funding sources to support the NCPs. Through WtW competitive grants awarded to Youthbuild USA and the Washington State Labor Council, services to NCPs are provided by programs operated by the Yakima Valley Opportunities Industrialization Center (OIC) and the Center for Administering Rehabilitation and Employment Services (IAM CARES), a nonprofit organization, respectively. Finally, state WtW match dollars are used to provide services to the NCPs through the AmeriCorps program. OIC and the AmeriCorps program specialize in serving young NCPs, and IAM CARES focuses on those with substance abuse problems.

\section{Funding Source(s) and Enrollment}

As described above, the SHARE program is funded by both WtW formula dollars, WtW competitive grants and state match funds. The program began operating in late August 1998; as of September 2000, the program had enrolled approximately 185 participants (100 at PFP, 50 at IAMCARES, 25 at OIC, and 10 at AmeriCorps). 


\section{Target Group}

The program serves NCPs who meet the WtW eligibility criteria, are behind in their child support payments or are having difficulty making payments, and reside in Yakima or Kittitas counties covered by the WtW grant. The NCPs must also meet the criteria for a contempt hearing: having a support order, failure to comply with the order, and a history of nonpayment.

\section{Incentives for Participation}

SHARE is a mandatory program. Eligible NCPs who cannot find work and cannot pay child support must participate in program services, or they will be referred for incarceration. In addition to program services, the program has important child support payment options to encourage participation: (1) payment agreements for less than the current amount for a temporary period, (2) reestablishing inaccurate default orders, and (3) the possibility of waiving arrears owed to the state. When the NCP begins working, the PA's office is notified and they may modify existing orders to ensure payment requirements are reasonable and may modify payments required to address arrearages.

\section{Outreach and Recruitment Strategies}

This program relies exclusively on the child support agency for referrals to the SHARE program; for the most part, it was able to supply a steady source of referrals. The program added a temporary staff person funded by WtW dollars to work directly at the child support office on identifying eligible NCPs; this strategy improved the number of referrals made to the PA's office.

When the NCP appears at court, the NCP is informed that if he cannot pay child support, he must participate in the SHARE program — which will assist him in obtaining employment—or be held in contempt of court and jailed. The PA's office has worked closely with the judges to inform them about the SHARE program; in some cases, participation in the SHARE program is written into the court order.

\section{Intake and Assessment}

WtW eligibility is determined by the child support office and verified when the individual arrives at one of the service providers. Those who are eligible for the program meet with a case manager for an assessment. Assessment is done through a one-on-one meeting with the case manager. The assessment process is intensive and covers a range of issues, including employment and education history, employment goals, family history, and potential employment barriers. At this meeting, the individual signs a personal responsibility contract that details the NCP's responsibilities in the program. 


\section{Case Management}

Case managers at PFP are responsible for intake and assessment and assist with a range of other issues that may affect an individual's ability to participate or become employed and pay child support, including family problems or other personal issues. They also are responsible for all planning and arranging for all job-related assistance, including job readiness services, job placement, job retention, referrals to education and training, and working with employers. The PA's office also remains involved in the monitoring of cases and conducts review hearings to check participant progress every 30 to 45 days.

\section{Employment and Postemployment Services}

Employment services are individualized to meet participants needs. Job search services are the primary employment activity in the SHARE program. Many SHARE participants participate in job search workshops and activities offered that are also attended by WtW and Workforce Investment Act clients. NCPs also participate in on-the-job training and work experience activities, although to a lesser extent than job search. Programs in Yakima have a history of providing subsidized employment options, and thus have experience in providing these types of services. These subsidized employment activities are also available to other $\mathrm{WtW}$ participants.

\section{Parenting and Relationship Services}

Case managers generally address parenting and relationship issues through informal counseling and assistance. More recently, PFP has taken the lead and started offering peer support sessions, which they developed on their own using a mix of different curricula. The plan is for the support sessions to be offered to all the NCPs in the near future.

\section{Other Services}

Referrals are made to outside organizations on an "as-needed" basis for a range of services, including anger management, mediation, and assistance on domestic violence. As noted above, individuals with substance abuse problems are referred to IAM CARES, an organization with experience serving this population. WtW funds are also available to meet transportation and short-term emergencies or needs.

\section{Contact Information}

Kathy Thomas

Tri-Valley Workforce Development Council

120 South 3rd Street, Suite 200-A

Yakima, WA 98901

(509) 574-1950

E-mail: kathyt@co.yakima.wa.us 
APPENDIX B

SUMMARY OF WtW AMENDMENTS 


\section{The 1999 Welfare-to-Work Amendments}

Title VIII of H.R. 3424,enacted as part of the Consolidated Appropriations Act for FY2000, contains the "Welfare to Work and Child Support Amendments of 1999" (1999 Amendments) These amendments make several significant changes to the Welfare-to-Work (WtW) grant programs administered by the Department of Labor. These changes, summarized below in question-and-answer format, are generally similar to those proposed by the Administration to allow WtW grantees to more effectively serve both long-term welfare recipients and noncustodial parents of low-income children, and to streamline $\mathrm{WtW}$ reporting requirements.

\section{How is eligibility changed under the 1999 WtW Amendments?}

\section{Required Beneficiaries/General Eligibility "The 70\% Eligibility Criteria"}

Old Requirement: As originally enacted, at least 70 percent of $\mathrm{WtW}$ grant funds had to be expended to provide services to long-term Temporary Assistance for Needy Families (TANF) recipients who met two of three specified barriers to employment and to noncustodial parents who met the barriers and whose children are long-term TANF recipients.

How do the 1999 WtW Amendments Change General Eligibility? The 1999 amendments remove the requirement that long-term TANF recipients must meet additional barriers to employment in order to be eligible for $\mathrm{WtW}$. Therefore, TANF recipients are eligible for $\mathrm{WtW}$ if they have received assistance for at least 30 months (whether consecutive or not), if they are within 12 months of reaching their TANF time limit, or if they have exhausted their receipt of TANF due to time limits.

In addition, under the 1999 amendments, noncustodial parents are eligible if: (1) they are unemployed, underemployed, or having difficulty paying child support obligations; (2) their minor children are eligible for, or receiving TANF benefits (with a priority for parents with children who are long-term recipients), received TANF benefits during the preceding year, or are eligible for, or receiving assistance under the Food Stamps program, the Supplemental Security Income program, Medicaid, or the Children's Health Insurance Program: AND (3) they enter into a personal responsibility contract under which they commit to cooperating in establishing paternity and paying child support, and participating in services to increase their employment and earnings, and to support their children. The 1999 amendments also require grantees to consult with domestic violence organizations in developing these projects to serve noncustodial parents.

\section{Other Eligibles - "The 30\% Eligibility Requirement"}

Old Requirement: As originally enacted, WtW grantees could also spend up to 30 percent of grant funds on TANF recipients and noncustodial parents who have characteristics associated with long-term dependency. 
How do the 1999 WtW Amendments Change Eligibility under the 30\% provision? In general, the $30 \%$ eligibility criteria are retained, except for noncustodials. In addition, the 1999 amendments add several categories of eligibility under the $30 \%$ provision, including 1) TANF recipients who have significant barriers to self-sufficiency under criteria established by the PIC, 2) youth aged 18 to 25 who have "aged out" of foster care, and 3) custodial parents with incomes below the poverty line.

Noncustodial parents are no longer included under the 30 percent provision, but may be served under the general eligibility provisions described above.

\section{What changes were made to WtW allowable activities?}

The 1999 Amendments add vocational education and job training as a separate allowable activity under WtW. Such training may be provided to a WtW participant for up to 6 months.

In addition, grantees that are not PICs or workforce investment boards may provide readiness, placement and post-employment services directly to WtW participants. As originally enacted, WtW grantees could generally only provide such services through contracts or vouchers.

\section{How will reporting changes affect current grantees?}

The $1999 \mathrm{WtW}$ Amendments eliminate the participant and financial reporting requirements as originally enacted and authorize the Secretary of Labor, in consultation with the Secretary of Health and Human Services as well as States, organizations representing States, and localities, to establish requirements for the collection and maintenance of financial and participant information and the reporting of such information. The Department expects to publish WtW participant and financial reporting requirements early in 2000 . WtW grantees will continue to operate under the current reporting requirements until reporting changes are published and become effective.

\section{How do the 1999 WtW Amendments effect grantees' access to information about potential WtW participants?}

Under the 1999 Amendments, State agencies responsible for enforcing child support orders (State IV-D agencies) have the authority to share information on noncustodial parents for the purpose of identifying and contacting them regarding participation in the WtW program. This information can include names, addresses, telephone numbers and identifying case number information, and can only be shared with WtW grantees who are PICs (or local workforce investment boards). The State must ensure that the PIC has procedures in place for safeguarding the privacy of this information and for ensuring that the information will be used solely for WtW recruiting purposes. 


\section{How do the 1999 Amendments affect the Performance Bonus for Formula grants?}

As originally enacted, $\$ 100$ million was set-aside from FY1999 funds to provide a bonus to successful States. The 1999 Amendments reduce the amount to $\$ 50$ million, and require that no outlays of these funds occur before October 1, 2000.

\section{When do the 1999 WtW Amendments take effect?}

WtW Competitive grantees may implement the new eligibility criteria and begin serving individuals under these criteria on January 1, 2000. Competitive grantees may also provide vocational education and job training immediately upon enactment. Further, competitive grantees who are not PICs (or local workforce investment boards) may immediately provide job placement, job readiness and post-employment services directly to WtW participants.

Formula grantees may implement the new eligibility criteria and begin serving individuals under these criteria, and providing vocational education and job training, as of July 1, 2000, except that federal formula funds may not be expended for these purposes until October 1, 2000.

For Indian and Native American grantees all applicable provisions are effective immediately.

The grid below outlines the various provisions and when they become effective for different types of grantees.

\section{Effective Dates}

\begin{tabular}{|c|c|c|c|c|}
\hline GRANTEE TYPE & \multicolumn{2}{|c|}{ Formula Grants } & \multirow[t]{2}{*}{$\begin{array}{c}\text { Competitive } \\
\text { Grants }\end{array}$} & \multirow[t]{2}{*}{$\begin{array}{c}\text { Indian/ } \\
\text { Native } \\
\text { American } \\
\text { Grants } \\
\end{array}$} \\
\hline $\begin{array}{l}\text { NOVEMBER } 1999 \\
\text { AMENDMENTS - } \\
\text { Eligibility and Allowable } \\
\text { Activities }\end{array}$ & & & & \\
\hline Expanded eligible population & $\begin{array}{l}\text { July } 1,2000 \text {, except that } \\
\text { no federal funds may be } \\
\text { expended }\end{array}$ & $\begin{array}{l}\text { October } 1,2000 \\
\text { (expending federal } \mathrm{WtW} \\
\text { funds permitted) }\end{array}$ & $\begin{array}{l}\text { January } 1, \\
2000\end{array}$ & $\begin{array}{l}\text { November } \\
29,1999\end{array}$ \\
\hline $\begin{array}{l}\text { Six month vocational } \\
\text { education } \\
\text { and job training allowed }\end{array}$ & $\begin{array}{l}\text { July } 1,2000 \text {, except that } \\
\text { no federal funds may be } \\
\text { expended }\end{array}$ & $\begin{array}{l}\text { October } 1,2000 \\
\text { (expending federal } \mathrm{WtW} \\
\text { funds permitted) }\end{array}$ & $\begin{array}{l}\text { November } \\
29,1999\end{array}$ & $\begin{array}{l}\text { November } \\
29,1999\end{array}$ \\
\hline
\end{tabular}


Allowable Activities

\begin{tabular}{|l|l|l|l|l|}
\hline GRANTEE TYPE & $\begin{array}{l}\text { Formula } \\
\text { Grants }\end{array}$ & Competitive Grants & $\begin{array}{l}\text { Indian/Native } \\
\text { American } \\
\text { Grants }\end{array}$ \\
\hline $\begin{array}{l}\text { NOVEMBER 1999 AMENDMENTS - } \\
\text { Other Provisions }\end{array}$ & & $\begin{array}{l}\text { Grantee is } \\
\text { PIC/local } \\
\text { board }\end{array}$ & $\begin{array}{l}\text { Grantee is not } \\
\text { PIC/local } \\
\text { board }\end{array}$ & \\
\hline $\begin{array}{l}\text { Information sharing between PICs/local } \\
\text { boards and Child Support Enforcement } \\
\text { agency }\end{array}$ & $\begin{array}{l}\text { November } \\
29,1999\end{array}$ & $\begin{array}{l}\text { November } \\
29,1999\end{array}$ & $\begin{array}{l}\text { Not } \\
\text { applicable. }\end{array}$ & Not applicable* \\
\hline $\begin{array}{l}\text { Direct provision of job readiness, job } \\
\text { placement and post-employment services }\end{array}$ & $\begin{array}{l}\text { Not } \\
\text { applicable* }\end{array}$ & $\begin{array}{l}\text { Not } \\
\text { applicable. }\end{array}$ & $\begin{array}{l}\text { November 29, } \\
\text { 1999 }\end{array}$ & $\begin{array}{l}\text { November 29, } \\
1999\end{array}$ \\
\hline
\end{tabular}

* Except in rare cases. 